UNIVERSIDADE ESTADUAL PAULISTA "JÚLIO DE MESQUITA FILHO" FACULDADE DE CIÊNCIAS AGRONÔMICAS

CÂMPUS DE BOTUCATU

\title{
EFEITO DO ARMAZENAMENTO NA QUALIDADE DOS GRÃOS E DO ÓLEO DE CRAMBE, PARA PRODUÇÃO DE BIODIESEL.
}

PEDRO HENRIQUE SILVA BEZERRA

Dissertação apresentado à Faculdade de Ciências Agronômicas da UNESP Campus de Botucatu, para obtenção do título de Mestre no Programa de pósgraduação em Agronomia (Energia na Agricultura).

BOTUCATU - SP

Março - 2014 
UNIVERSIDADE ESTADUAL PAULISTA “JÚLIO DE MESQUITA FILHO” FACULDADE DE CIÊNCIAS AGRONÔMICAS

CÂMPUS DE BOTUCATU

\section{EFEITO DO ARMAZENAMENTO NA QUALIDADE DOS GRÃOS E DO ÓLEO DE CRAMBE, PARA PRODUÇÃO DE BIODIESEL.}

\section{PEDRO HENRIQUE SILVA BEZERRA}

Engenheiro Agrícola

Orientador: Prof. Dr. Marco Antonio Martin Biaggioni

Dissertação apresentado à Faculdade de Ciências Agronômicas da UNESP Campus de Botucatu, para obtenção do título de Mestre no Programa de pósgraduação em Agronomia (Energia na Agricultura).

BOTUCATU - SP

Março - 2014 
FICHA CATALOGRÁFICA ELABORADA PELA SEÇÃo TÉCNICA DE AQUISIÇÃO E TRATAMENTO DA INFORMAÇÃO - SERVIÇO TÉCNICO DE BIBLIOTECA E DOCUMENTAÇÃ̃O - UNESP - FCA - LAGEADO- BOTUCATU (SP

Bezerra, Pedro Henrique Silva, 1988-

B574e Efeito do armazenamento na qualidade dos grãos e do óleo de crambe, para produção de biodiesel / Pedro Henrique Silva Bezerra. - Botucatu : [s.n.], 2014

v, 70 f. : il., color., grafs., tabs.

Dissertação(Mestrado) - Universidade Estadual Paulista, Faculdade de Ciências Agronômicas, Botucatu, 2014

Orientador: Marco Antonio Martin Biaggioni

Inclui bibliografia

1. Biocombustíveis. 2. Embalagens. 3. Grãos - Armazenamento. 4. Plantas oleaginosas. I. Biaggioni, Marco Antonio Martin. II. Universidade Estadual Paulista "Júlio de Mesquita Filho" (Campus de Botucatu). Faculdade de Ciências Agronômicas de Botucatu. III. Título. 


\section{UNIVERSIDADE ESTADUAL PAULISTA “JÚLIO DE MESQUITA FILHO” FACULDADE DE CIÊNCIAS AGRONÔMICAS \\ CAMPUS DE BOTUCATU \\ CERTIFICADO DE APROVAÇÃO}

\section{'ÍTULO: "EFEITO DO ARMAZENAMENTO NA QUALIDADE DOS GRÃOS E DO ÓLEO DE CRAMBE, PARA PRODUÇÃO DE BIODIESEL"}

ALUNO: PEDRO HENRIQUE SILVA BEZERRA

ORIENTADOR: PROF. DR. MARCO ANTONIO M. BIAGGIONI

Aprovado pela Comissão Examinadora

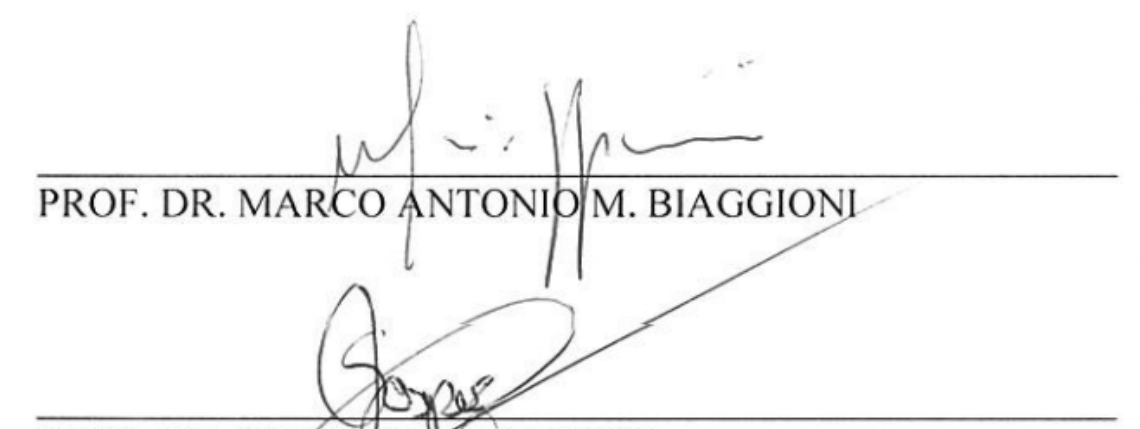

PROF. DR. SAMIR PAELO JASPER

Data da Realização: 07 de março de 2014. 


\title{
DEDICATÓRIA
}

\author{
Dedico este trabalho
}

à Deus por me proporcionar a vida e seu sentido, aos meus pais

Roberto Carlos Moraes Bezerra e Sílvia Maria Cavalcante Silva Bezerra, pelo constante apoio, incentivo e por nunca mediram esforços para me ajudar nessa trajetória,
ao meu irmão Bruno Silva Bezerra, à minha irmã Roberta Silva Bezerra
e à minha namorada Caroline Alves. 


\section{AGRADECIMENTOS}

Á Deus, meu fundamento e meu consolador,

Ao Prof. Dr. Marco Antonio Martin Biaggioni, pela orientação na elaboração e condução deste trabalho, pelo empenho e pela disposição, pelos conselhos e direcionamentos durante o mestrado.

Agradeço à Faculdade de Ciências Agronômicas e à coordenação do curso de PósGraduação Energia na Agricultura, por me proporcionar essa oportunidade de estudo e desenvolvimento profissional.

Aos colegas Felipe, Fernando e Magnum pela ajuda na condução do experimento.

Aos meus pais, que sempre estiveram comigo, me apoiando e incentivando em todos os aspectos.

À minha namorada, pela parceria, compreensão e companheirismo. 


\section{SUMÁRIO}

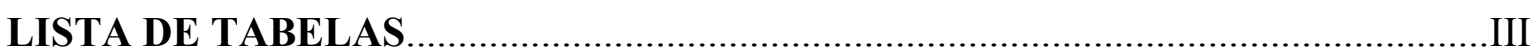

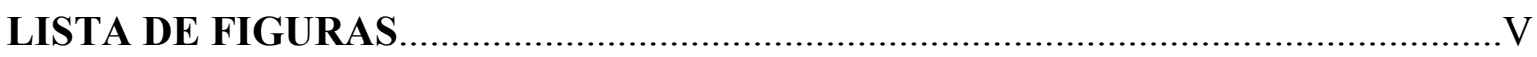

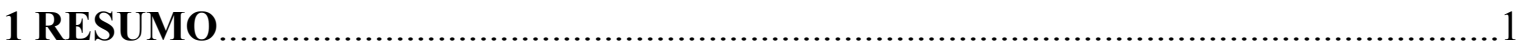

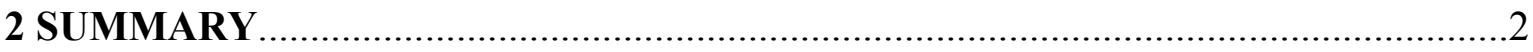

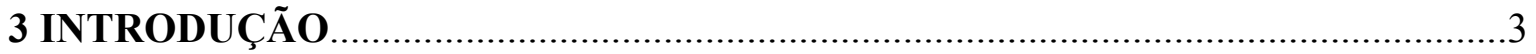

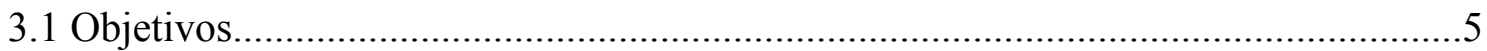

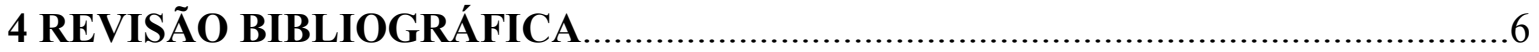

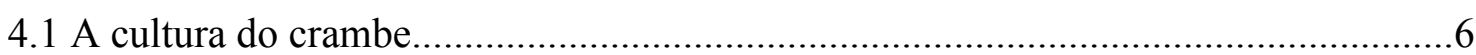

4.2 Métodos de Armazenamento dos grãos............................................................... 8

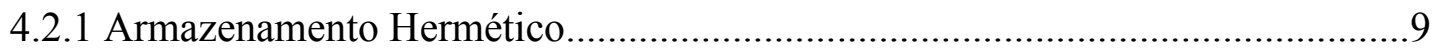

4.2.2 Armazenamento Convencional..................................................................... 10

4.3 Efeito do ambiente de armazenamento na qualidade dos grãos...............................11

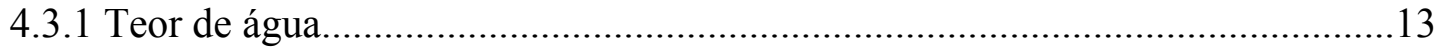

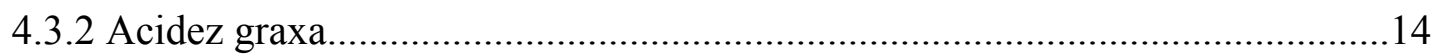

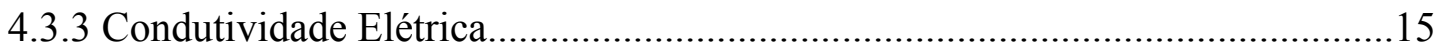

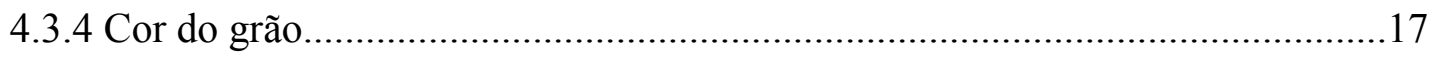

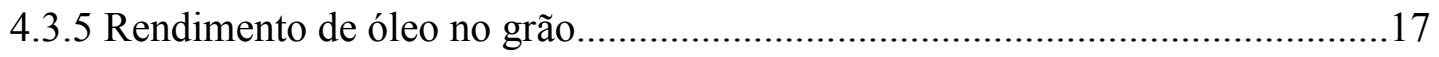

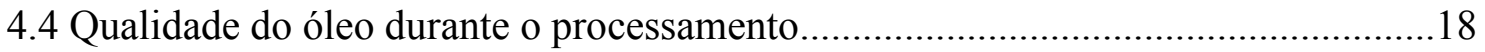

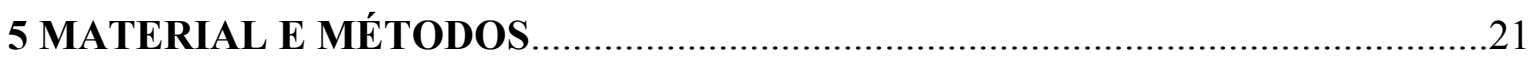

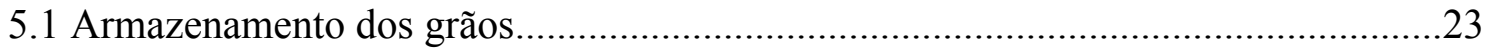

5.2 Delineamento experimental e análises estatísticas.................................................25

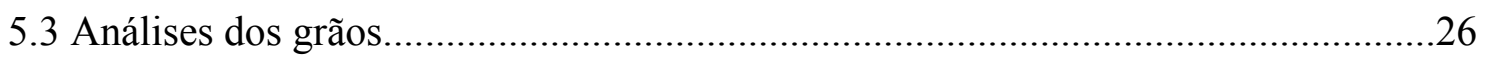

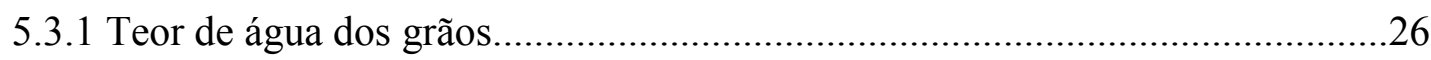

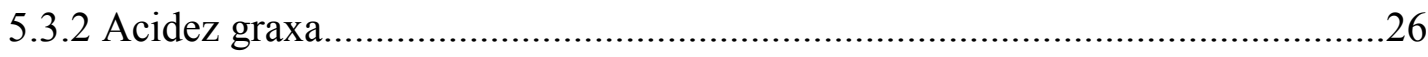

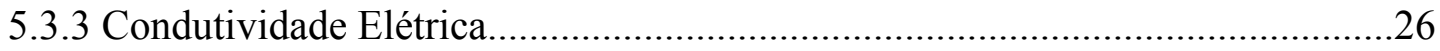

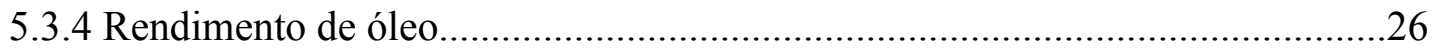

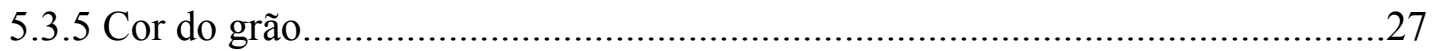

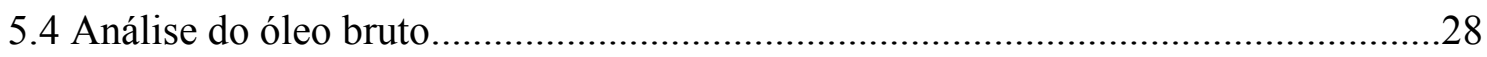

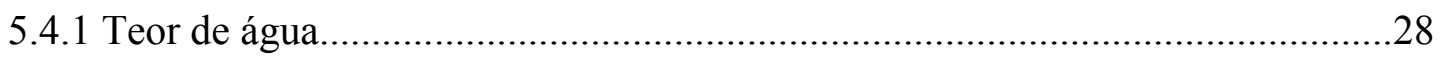

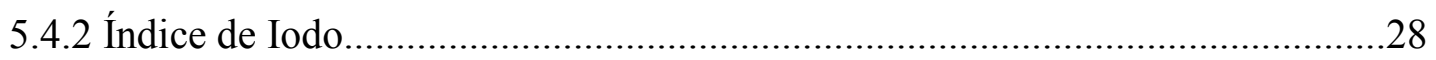

5.4.3 Índice de Acidez........................................................................................29 


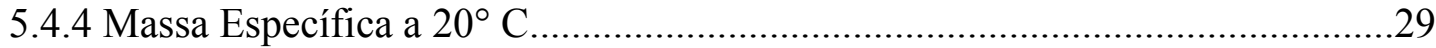

5.4.5 Viscosidade Cinemática a $40^{\circ} \mathrm{C}$..................................................................29

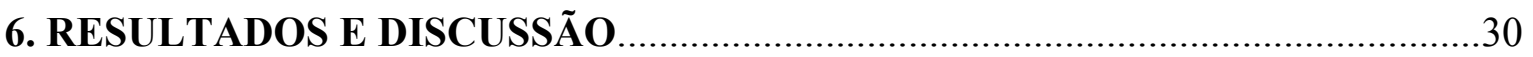

6.1 Caracterização das condições do armazenamento ................................................. 30

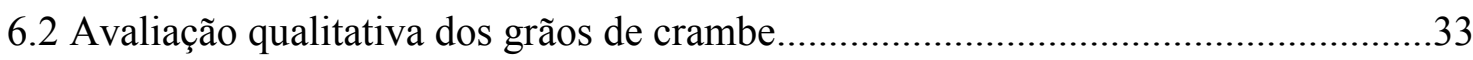

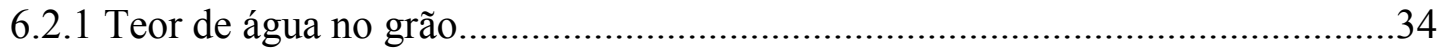

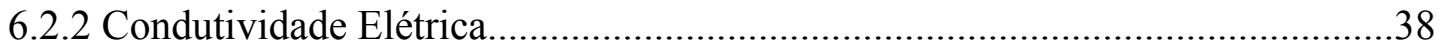

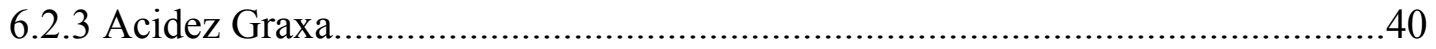

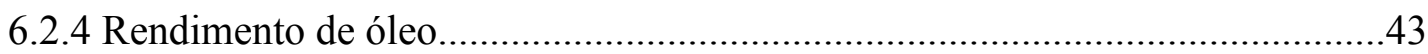

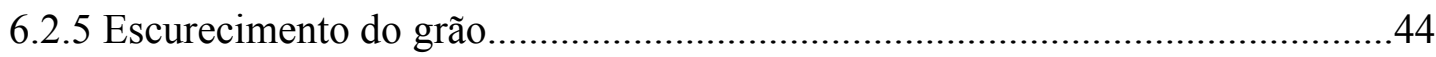

6.3 Avaliação qualitativa do óleo bruto extraído de crambe...........................................46

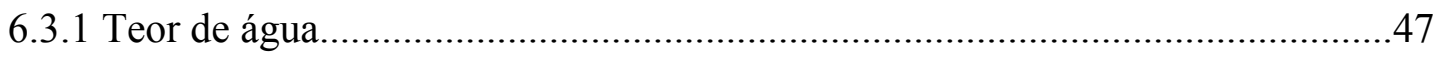

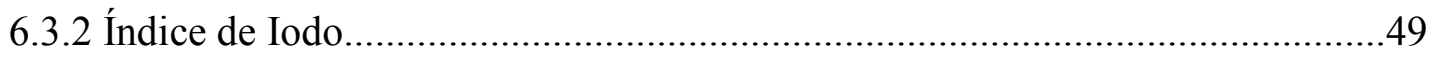

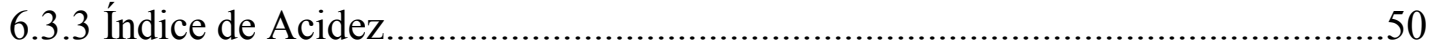

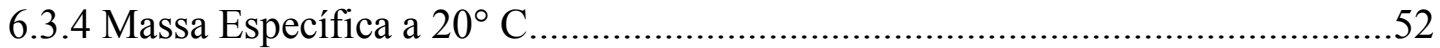

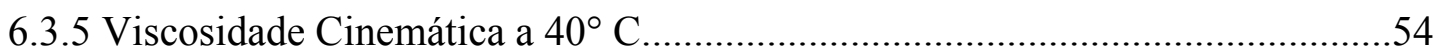

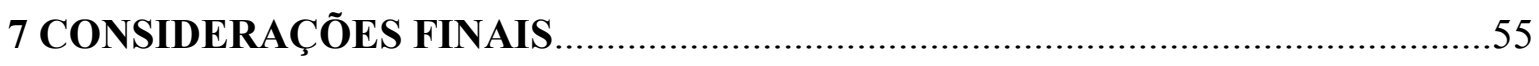

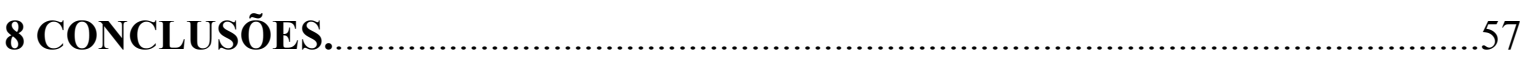

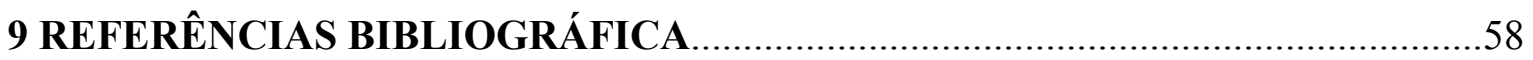




\section{LISTA DE TABELAS}

Tabela 01. Síntese da análise de variância e do teste de médias do teor de água (TA - \% b.u), condutividade elétrica ( $\mathrm{CE}-\mu \mathrm{S} \mathrm{cm}^{-1} \mathrm{~g}^{-1}$ ), acidez graxa (AG - mL KOH 0,1N 100g${ }^{1} \mathrm{MS}$ ), teor de óleo (TO - \%) e porcentagem de grãos escurecidos (EG - \%) nos grãos de crambe armazenados em dois tipos de embalagens e três ambientes, ao longo do tempo.

Tabela 2. Valores médios do teor de água (\% b.u.) nos grãos de crambe armazenados em dois tipos de embalagens e três ambientes.

Tabela 3. Valores médios do teor de água (\% b.u.) nos grãos de crambe armazenados em dois tipos de embalagens ao longo do tempo

Tabela 4. Valores médios do teor de água (\% b.u.) nos grãos de crambe armazenados em três ambientes ao longo tempo .36

Tabela 5. Valores médios do teor de água (\% b.u.) nos grãos de crambe armazenados em dois tipos de embalagens e três ambientes, ao longo do tempo

Tabela 6. Valores médios de condutividade elétrica $\left(\mathrm{CE}-\mu \mathrm{S} \mathrm{m}^{-1} \mathrm{~g}^{-1}\right)$ nos grãos de crambe armazenados em dois tipos de embalagens e três ambientes. .38

Tabela 7. Valores médios de condutividade elétrica $\left(\mathrm{CE}-\mu \mathrm{S} \mathrm{m}^{-1} \mathrm{~g}^{-1}\right)$ nos grãos de crambe armazenados em dois tipos de embalagens ao longo do tempo. .39

Tabela 8. Valores médios de condutividade elétrica $\left(\mathrm{CE}-\mu \mathrm{S} \mathrm{cm}^{-1} \mathrm{~g}^{-1}\right)$ nos grãos de crambe armazenados em três ambientes ao longo do tempo

Tabela 9. Valores médios de condutividade elétrica $\left(\mathrm{CE}-\mu \mathrm{S} \mathrm{cm}^{-1} \mathrm{~g}^{-1}\right)$ nos grãos de crambe armazenados em dois tipos de embalagens e três ambientes, ao longo do tempo.

Tabela 10. Valores médios de acidez graxa (AG - mL KOH $0,1 \mathrm{~N} 100 \mathrm{~g}^{-1} \mathrm{MS}$ ) nos grãos de crambe armazenados em dois tipos de embalagens e três ambientes.

Tabela 11. Valores médios de acidez graxa (AG - mL KOH $0,1 \mathrm{~N} 100 \mathrm{~g}^{-1} \mathrm{MS}$ ) nos grãos de crambe armazenados em dois tipos de embalagens ao longo do tempo

Tabela 12. Valores médios de acidez graxa (AG - mL KOH $0,1 \mathrm{~N} 100 \mathrm{~g}^{-1} \mathrm{MS}$ ) nos grãos de crambe armazenados em três ambientes ao longo do tempo.

Tabela 13. Valores médios de acidez graxa ( $\mathrm{AG}-\mathrm{mL} \mathrm{KOH} 0,1 \mathrm{~N} 100 \mathrm{~g}^{-1} \mathrm{MS}$ ) nos grãos de crambe armazenados em dois tipos de embalagens e três ambientes, ao longo do tempo...42 
Tabela 14. Valores médios do teor de óleo (\%) nos grãos de crambe armazenados em dois tipos de embalagens e três ambientes.

Tabela 15. Porcentagem média de grãos de crambe escurecidos armazenados em dois tipos de embalagens ao longo do tempo.

Tabela 16. Porcentagem média de grãos de crambe escurecidos nos grãos de crambe armazenados em três ambientes ao longo do tempo

Tabela 17. Síntese da análise de variância e do teste de médias para o teor de água (TAO ppm), índice de iodo (II - g $100 \mathrm{~g}_{\text {amostra }^{-1}}$ ), índice de acidez (IA - mg KOH g amostra ${ }^{-1}$ ), viscosidade cinemática $\left(\mathrm{VC}-\mathrm{mm}^{2} / \mathrm{s}\right)$ e da massa específica $\left(\mathrm{ME}-\mathrm{g} / \mathrm{cm}^{3}\right)$ do óleo bruto extraído de grãos de crambe armazenados em dois tipos de embalagens e três ambientes, ao longo do tempo. .57

Tabela 18. Valores médios do Teor de água (ppm) no óleo bruto extraído de grãos de crambe armazenados em dois tipos de embalagens e três ambientes, ao longo do tempo crambe em cada método de armazenamento.

Tabela 19. Valores médios do Índice de Iodo $\left(\mathrm{g} 100 \mathrm{~g}_{\text {amostra }^{-1}}\right)$ do óleo bruto extraído de grãos de crambe armazenados em dois tipos de embalagens ao longo do tempo.

Tabela 20. Valores médios do Índece de Acidez (mg KOH g $\operatorname{amostra}^{-1}$ ) do óleo bruto extraído de grãos de crambe armazenados em dois tipos de embalagens e três ambientes.50 Tabela 21. Valores médios do Índece de Acidez (mg KOH g $\operatorname{amostra}^{-1}$ ) do óleo bruto extraído de grãos de crambe armazenados em dois tipos de embalagens ao longo do tempo.

Tabela 22. Valores médios do Índece de Acidez (mg KOH g amostra ${ }^{-1}$ ) do óleo bruto extraído de grãos de crambe armazenados em três ambientes ao longo do tempo .51

Tabela 23 Valores médios de Viscosidade Cinemática $\left(\mathrm{mm}^{2} / \mathrm{s}\right)$ do óleo bruto extraído de grãos de crambe armazenados em dois tipos de embalagens e três ambientes.

Tabela 24. Valores médios de Viscosidade Cinemática $\left(\mathrm{mm}^{2} / \mathrm{s}\right)$ do óleo bruto extraído de grãos de crambe armazenados em dois tipos de embalagens ao longo do tempo .52 Tabela 25. Valores médios de Viscosidade Cinemática $\left(\mathrm{mm}^{2} / \mathrm{s}\right)$ do óleo bruto extraído de grãos de crambe armazenados em três ambientes ao longo do tempo. .53 Tabela 26. Valores médios da Massa Específica $\left(\mathrm{g} / \mathrm{cm}^{3}\right)$ do óleo bruto extraídos de grãos de crambe armazenados em três ambientes ao longo do tempo. . .54 


\section{LISTA DE FIGURAS}

Figura 1. Colheita mecânica de crambe seco naturalmente na planta, na área experimental de produção de crambe, na Fazenda Lageado, FCA, UNESP, BotucatuSP

Figura 2. (A) Área experimental de produção de crambe e (B) foto da planta com flores .22

Figura 3. Embalagens mini-bolsas herméticas e sacaria convencional.............................23

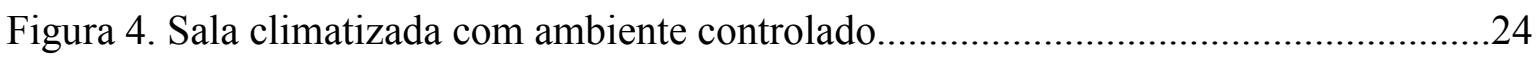

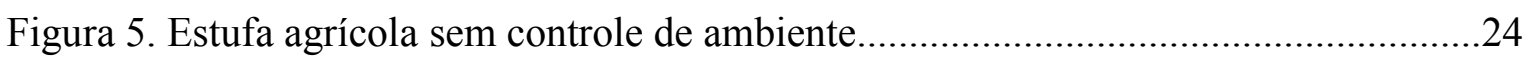

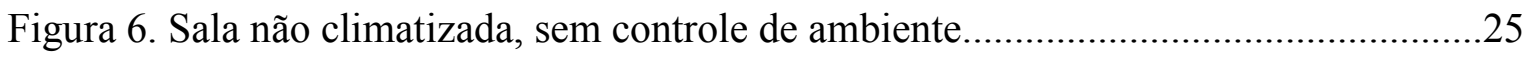

Figura 7: Carta de Munsell utilizada na classificação visual da porcentagem de grãos escurecidos de crambe (MUNSELL, 1976)

Figura 8. Exemplo de classificação de grãos de crambe, segundo a carta de Munsell

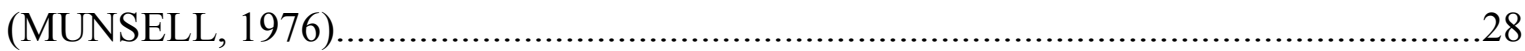

Figura 9. Valores médios mensais da temperatura $\left({ }^{\circ} \mathrm{C}\right)$ e umidade relativa do ar (\%) na estufa agrícola durante o armazenamento dos grãos de crambe 31

Figura 10. Valores médios mensais da temperatura $\left({ }^{\circ} \mathrm{C}\right)$ e umidade relativa do ar (\%) no ambiente testemunha durante o armazenamento dos grãos de crambe .31

Figura 11. Valores médios da temperatura $\left({ }^{\circ} \mathrm{C}\right)$ e umidade relativa do ar (\%) mensal na câmara climatizada durante o armazenamento dos grãos de crambe .32 


\section{RESUMO}

O crambe, devido a sua riqueza em óleo vegetal é uma ótima opção para a produção de biodiesel. $\mathrm{O}$ armazenamento é prática fundamental para a qualidade fisiológica do grão. As embalagens utilizadas devem ajudar a diminuir a velocidade do processo de deterioração, mantendo a qualidade do grão. Diferentes combinações de práticas de manejo e condições ambientais afetam a capacidade de armazenamento de grãos em silo bolsa e sacaria, proporcionando maior preservação da matéria prima para a extração do óleo. Dessa maneira, o presente trabalho tem como objetivos avaliar a qualidade do grão e do óleo de crambe submetido a diferentes condições de armazenamento, visando à produção de biodiesel. O delineamento experimental foi inteiramente casualizado, fatorial triplo, com dois tipos de embalagens, três condições de ambiente e três períodos de armazenamento e com três repetições. As análises de qualidade dos grãos foram teor de água, acidez graxa, condutividade elétrica, cor e rendimento de óleo. As análises de qualidade do óleo foram: índice de iodo, viscosidade, massa específica, índice de acidez e teor de água. Os resultados foram submetidos à análise de variância e as médias comparadas pelo teste de "t" à $5 \%$ de probabilidade. Os resultados apontam que a embalagem hermética resistiu às influências do armazenamento e manteve a qualidade dos grãos e do óleo, o tempo de 12 meses apresentou níveis inseguros de qualidade e o ambiente câmara climatizada apresentou evidencias de deterioração em todos os quesitos avaliativos, nas embalagens e bolsa hermética e sacaria convencional.

Palavras-chave: Biocombustíveis, embalagem, armazenamento, oleaginosa. 
EFFECT OF STORAGE OF GRAIN IN THE QUALITY OIL AND BIODIESEL CRAMBE. Botucatu, 2014. 74 p. Dissertação (Mestrado em Agronomia/Energia na Agricultura) - Faculdade de Ciências Agronômicas, Universidade Estadual Paulista. Author: Pedro Henrique Silva Bezerra Adviser: Marco Antonio Martin Biaggioni

\section{SUMMARY}

The crambe, due to its richness in vegetable oil is a great option for the production of biodiesel. Storage is essential for the physiological quality of the grain practice. Packaging used should help slow the process of deterioration, maintaining grain quality. Different combinations of management practices and environmental conditions affect the ability of grain storage silo bag and sacks, providing greater preservation of raw material for the extraction of oil. Thus, this study aims to evaluate the quality of grain and crambe oil under different storage conditions, aiming at the production of biodiesel. The experimental design was completely randomized, triple factorial, with two types of packaging, three environmental conditions and three storage periods, with three replications. Analysis of grain quality were water content, fat acidity, electrical conductivity, color and oil yield. The analysis of oil quality were: iodine value, viscosity, density, acid value and water content. The results were subjected to analysis of variance and means were compared by the " $\mathrm{t}$ " test at $5 \%$ probability. The results show that the hermetic packaging resisted the influences of storage and kept the quality of grain and oil, the time 12 months had unsafe levels of quality and climatic chamber environment showed evidence of deterioration in all evaluative questions, packaging and bag and conventional hermetic sacks.

Keywords: Biofuels, packing, storage, oilseed. 


\section{INTRODUÇÃO}

A maior parte de toda a energia consumida no mundo provém do petróleo, do carvão mineral e do gás natural. Contudo, a limitação destas fontes não renováveis, e os problemas ambientais gerados despertam a preocupação pela procura de fontes de energia renováveis (GOLDEMBERG, 2009). Os impactos ambientais causados pelo uso de combustíveis feitos de fontes fósseis e as preocupações sobre os estoques de petróleo bruto foram motivando estudos e pesquisas para fontes renováveis de combustíveis, principalmente para a substituição do diesel.

O biodiesel tem se mostrado como excelente substituto para o diesel mineral. Neste contexto, a demanda por óleos vegetais é crescente, devido ao aumento do consumo per capita dos países emergentes e pela sua utilização na produção de biodiesel, que é considerada a nova alavanca de impulso na produção de óleos vegetais (LAZZAROTTO; HIRAKURI, 2009).

Por ser uma espécie em que o grão tem alto teor de óleo vegetal e não apresenta aproveitamento alimentício pela presença de ácido erúcico, o crambe mostra potencial à produção de biodiesel. É uma planta de cultivo totalmente mecanizado, podendo-se utilizar maquinários existentes para o cultivo de grãos miúdos em sua produção. Além disso, se destaca por boa adaptação, rusticidade, precocidade e bom potencial produtivo (Plein et al., 2010). É resistente à seca e a geadas e, ainda, constitui-se numa boa opção para a safrinha por se tratar de uma cultura de inverno. Seu ciclo é, em média, de 90 dias e atinge uma produtividade entre 1000 e 1500 quilos por hectare. 
Além da produção de biodiesel, o óleo obtido a partir dos grãos de crambe pode ser usado como lubrificante industrial, e na fabricação de borracha sintética, pelo seu alto conteúdo em ácido erúcico (50 a 60\% do óleo). Ainda se compreende a utilização deste óleo na fabricação de plásticos, adesivos e isolação elétrica (SANTOS et al., 2012)

Há muito que se pesquisar para consolidar a produção da cultura do crambe em nosso país, se destacando os processos de secagem e armazenamento visando manter sua qualidade, para um melhor aproveitamento de toda a produção, culminando em diminuição de perdas. O conhecimento das características físicas e químicas dos grãos pode auxiliar a minimizar esses problemas, através da aplicação de manejo adequado apoiado em bases científicas (OLIVEIRA, 2011).

Ao se industrializar os grãos, visando se produzir simultaneamente biodiesel e óleos comestíveis, os períodos de armazenamento aumentaram em muito e não há estudos de conservabilidade que garantam a armazenagem sequer por períodos médios, muito menos por longos períodos, com segurança operacional a cada cadeia produtiva (OLIVEIRA, 2008).

O armazenamento é prática fundamental para o controle da qualidade fisiológica do grão, sendo um método pelo qual se pode preservar a viabilidade e manter o seu vigor (AZEVEDO et al., 2003) por um período mais prolongado. O conhecimento sobre a capacidade de armazenamento dos grãos permite que sejam adotadas condições adequadas para cada espécie (DAVIDE et al. 2003).

As embalagens utilizadas no armazenamento devem ajudar a diminuir a velocidade do processo de deterioração, mantendo o teor de água inicial das sementes armazenadas, com o intuito de diminuir a respiração (Tonin \& Perez 2006).

Segundo Villers et al. (2010), o armazenamento hermético mostrou-se um método de sucesso para a proteção dos grãos, substituindo agroquímicos no controle de insetos e também para a preservação da qualidade dos produtos armazenados, proporcionando condições adequadas para períodos longos de armazenamento.

O armazenamento em bolsas de polietileno, seladas hermeticamente, tem sido avaliado e utilizado para o armazenamento de soja, trigo e milho no Brasil e na Argentina como uma alternativa à grande demanda por unidades armazenadoras no campo (COSTA et al. 2010). 
Diretrizes de armazenamento seguro são necessárias para todos os tipos de grãos, como teor de água e temperaturas esperadas durante o armazenamento. Isso concede informações aos agricultores para auxiliá-los na programação de diferentes tratamentos pós-colheita antes da degradação e perda da qualidade dos grãos (SATHYA et al. 2009).

A compreensão de diferentes combinações como da condição inicial dos grãos, práticas de manejo no armazenamento e condições ambientais afetam a capacidade de armazenamento de grãos em silo bolsa e sacaria e é fundamental para os agricultores e para a indústria de grãos (CARDOSO et al. 2008).

\subsection{OBJETIVOS}

O presente trabalho tem como objetivos avaliar a qualidade do grão e do óleo de crambe submetido a diferentes condições de armazenamento, visando a produção de biodiesel. 


\section{REVISÃO DE LITERATURA}

\subsection{A cultura do crambe}

O crambe (crambe abyssinica Hochst. exFries) é uma planta de ciclo anual, pertencente à família Brassicaceae. Nativo do Mediterrâneo e cultivado em algumas regiões tropicais e subtropicais pelo interesse industrial no óleo extraído destas sementes, e mais recentemente, para produção de óleo para biodiesel (CARNEIRO et al., 2008).

As sementes de crambe são albuminosas, ortodoxas, do tipo cariopse e tem seu eixo embrionário curvo, com presença de plúmula protegida por uma fina cobertura mucilaginosa (SOUZA et al., 2009; CRUCIFERAE, 1985). As sementes também apresentam elevado potencial lubrificante e teor de óleo, com valores entre 30 e $45 \%$ da semente (TOEBE, 2010).

Possuem forma esférica envolta por uma estrutura tegumentar denominada pericarpo, com a função básica de proteger as sementes contra abrasões e choque, funcionando como barreira para a entrada de microrganismos, permitindo - lhes que possam ser armazenadas por longos períodos (PEREZ, 1998). Ainda mostram - se mais resistentes à degradação, conferindo vantagens relacionadas ao tempo de armazenamento, sendo este um ponto extremamente importante, uma vez que a maioria do biodiesel gerado por diversos óleos vegetais não apresenta esta estabilidade (BISPO et al., 2010). 
A planta caracteriza-se por ser um vegetal arbustivo e por se desenvolver em regiões com condições climáticas diferenciadas, desde o Sul do Brasil até o Centro-Oeste. O crambe se mostra como uma interessante fonte de óleo vegetal, sendo assim uma cultura promissora para a produção de biodiesel (BERALDO et al. 2010).

A produção de crambe tem como vantagens o cultivo totalmente mecanizado, utilizando os mesmos equipamentos existentes para outras culturas, e a possibilidade de cultivo no inverno. Por ser uma cultura pouco conhecida comercialmente, praticamente não se dispõe, ainda, de informações técnicas que viabilize seu cultivo intensivo (OLIVA, 2010). É tolerante à geada e, após seu estabelecimento, é altamente resistente à seca. O crambe apresenta boa produtividade na estação seca, por ser uma cultura de inverno mostrando ser uma boa alternativa para a safrinha (OPLINGER, 1991; MEAKIN, 2001).

A princípio, as pesquisas iniciais sobre a cultura visavam a utilização da planta como forrageira, alternativa na rotação de culturas e cobertura de solos para o plantio direto no período de inverno. Contudo, mais tarde, foi descoberto o alto potencial das sementes para a produção de óleo vegetal, a partir do que as pesquisas acabaram chegando à sua utilização como matéria-prima para o biodiesel (FARIA, 2010).

Em diversos estudos realizados, observou-se um potencial de produtividade do crambe em torno de 1000 a $1500 \mathrm{Kg}^{-h^{-1}}$ (FUNDAÇÃO MS, 2007). Jasper (2009), em experimento de crambe produzido em plantio direto em Botucatu-SP, encontrou produtividade média de $1507,05 \mathrm{Kg}_{\mathrm{h}} \mathrm{h}^{-1}$ o que demonstra boa aptidão da cultura à região. Segundo Ferreira e Berchol Silva (2011), no Brasil em 2009, o plantio de crambe alcançou mais de 10.000 ha, destacando-se o Sudeste de Goiás e o Sul do Mato Grosso do Sul.

De acordo com Pitol et al. (2010), quando o crambe é semeado na safrinha, constitui uma excelente opção para a rotação de culturas, por ser uma cultura de ciclo considerado curto, de aproximadamente 90 dias, ainda têm rusticidade, precocidade, grande tolerância ao déficit hídrico, e cultivo mecanizável, que utiliza os mesmos implementos de culturas tradicionais produtoras de grãos, maximizando o uso de máquinas e equipamentos agrícolas.. 


\subsection{Métodos de Armazenamento dos grãos}

O armazenamento visa a conservação da qualidade dos grãos, utilizando o controle das condições ambientais para a manutenção da viabilidade do produto armazenado. $\mathrm{O}$ armazenamento seguro pode ser definido como o período de tempo durante o qual os grãos podem ser armazenados sem perda significativa na sua qualidade e quantidade. Os problemas encontrados no armazenamento de produtos agrícolas constituem objeto de estudo permanente, visando prolongar ao máximo a qualidade dos produtos armazenados, sejam eles semente ou grão para consumo (BRANGANTINI, 2005).

O armazenamento é uma etapa de suma importância na cadeia agroindustrial, pois tem um grande reflexo no custo e afeta diretamente a qualidade do produto que chega à mesa do consumidor. (CONAB, 2012).

Os principais fatores externos que afetam o ecossistema da massa de grãos são a temperatura e a umidade relativa que prevalecem no local de armazenamento. A variação da temperatura ambiente pode ser extrema, desde valores abaixo de zero até acima de $40^{\circ} \mathrm{C}$, podendo ter implicações positivas e negativas na extensão das perdas durante a armazenagem. Também a umidade relativa pode apresentar grandes variações, desde 10 a 20\% nos desertos, até $90 \%$ ou mais nos trópicos. O efeito combinado da umidade relativa e da temperatura em um determinado local de armazenamento determina a atividade de todos os componentes bióticos do sistema, os quais conduzem a um armazenamento seguro ou a perdas do produto (ELIAS, 2002).

A predição das condições de armazenamento seguro permite a preservação de características qualitativas de grãos recém colhidos por um longo período, podendo evitar que ocorra uma significativa deterioração. Segundo Fleuratlessard (2002), os grãos armazenados em recipientes permeáveis, como em sacaria, têm o seu teor de água frequentemente alterado pelas oscilações da umidade relativa do ar atmosférico. Em recipientes hermeticamente fechados, como em silos bolsa dá-se o fenômeno inverso, isto é, a umidade relativa do ar do recipiente é que será afetada pela umidade do grão.

O que se deseja no armazenamento de grãos é propiciar meios de manutenção, durante o período de estocagem, das características biológicas, químicas e físicas que eles possuíam imediatamente após a colheita. A temperatura e o teor de água são fatores fisiológicos críticos e determinantes no sucesso do processo de armazenagem 
de grãos. Elevado teor de água dos grãos ocasiona problemas durante o armazenamento, por criar condições favoráveis ao desenvolvimento de insetos e fungos, além do aumento da taxa de respiração. (SILVA, 2000).

\subsubsection{Armazenamento Hermético}

A embalagem hermética é uma das alternativas de armazenamento de grãos que se apresenta, porém são escassas as informações sobre os efeitos deste sistema sobre qualidade dos grãos e do óleo. As condições herméticas de armazenamento propiciam maior estabilidade higroscópica dos grãos, a qual é representada pelas pequenas variações de umidade.

A utilização de bolsas seladas hermeticamente para o armazenamento de grãos é uma tecnologia alternativa aos métodos tradicionais de armazenagem em fazenda e que tem merecido devida atenção e tem sido alvo de diversas pesquisas (FARONI et al., 2009). De acordo com Darby \& Caddick (2007), a técnica consiste em sacos de armazenamento impermeáveis, hermeticamente fechados, de polietileno. Os sacos têm uma parede branca do lado de fora, o que reflete $20 \%$ da luz solar, e uma parede interior negra, o que mantém o material no escuro, retardando assim o escurecimento do tegumento. Ele também evita a ocorrência de alterações na umidade do produto, evitando o contato com o ambiente externo.

Weinberg et al. (2008b) examinando o efeito do armazenamento hermético em escala laboratorial, na qualidade de grãos de milho em Israel, relatou que os grãos com teores de água com valores de 16-22\% foram armazenados em recipientes hermeticamente fechados, sem ocorrer deterioração. A prevenção da deterioração do milho sob tais condições é devido aos ambientes de atmosfera controlada anaeróbios obtidos em recipientes selados hermeticamente. Os grãos armazenados a 20-22\% de umidade obtiveram perdas de matéria seca que foram significativamente maiores do que os grãos mais secos. Os resultados obtidos foram animadores para justificar novos ensaios em escala comercial, no armazenamento de milho para produção de etanol.

Analisando o efeito da embalagem hermética em grãos, BERTINETTI et. al (2011) observaram resultados que mostram que o sistema de armazenamento hermético é promissor como alternativa, e revelaram a necessidade de 
serem realizados mais estudos acerca desta tecnologia de armazenagem e que as condições herméticas de armazenamento propiciam maior estabilidade higroscópica dos grãos.

Essa técnica consiste no armazenamento de grãos em bolsas plásticas seladas hermeticamente, em que o processo respiratório dos componentes bióticos do ecossistema (grãos, fungos, insetos, etc.) consome o oxigênio $\left(\mathrm{O}_{2}\right)$ gerando dióxido de carbono $\left(\mathrm{CO}_{2}\right)$. Uma atmosfera rica em $\mathrm{CO}_{2}$ e pobre em $\mathrm{O}_{2}$ pode diminuir a capacidade de reprodução e/ou desenvolvimento de insetos e de fungos, como também a própria atividade metabólica dos grãos, favorecendo a sua conservação, além de reduzir a taxa de oxidação do produto armazenado (VILLERS et al., 2006).

Rupollo et al. (2006) afirmam que no armazenamento hermético, o $\mathrm{CO}_{2}$ gerado e, consequentemente, a redução do $\mathrm{O}_{2}$ no sistema, estabiliza o processo de degradação da massa de grãos pela redução da taxa respiratória dos próprios grãos e organismos presentes. Neste contexto, o manejo pós-colheita inadequado pode ocasionar rápida deterioração do produto, gerando perdas do ponto de vista nutricional e redução do valor comercial (REED et al., 2007).

\subsubsection{Armazenamento Convencional}

A armazenagem convencional, extensivamente utilizada no Brasil, usa estruturas como armazéns e/ou depósitos de construção relativamente simples, de alvenaria ou madeira, na quase totalidade, com o acondicionamento dos grãos em sacaria. A maior área específica de trocas térmicas e hídricas, o maior espectro de contaminação microbiana e ataque de insetos, ácaros e roedores durante o armazenamento, o custo da embalagem e menor operacionalidade são importantes limitações da estocagem convencional (PUZZI, 1986; ELIAS et al, 1994).

O sistema convencional de armazenagem possui como principal vantagem a versatilidade na estocagem de vários produtos, na mesma construção, embora não aceite automatização no manuseio, nem o controle da qualidade durante $o$ armazenamento. Oliveira (2010) relata que os grãos armazenados em ambiente convencional sem o controle de temperatura e umidade relativa, apresentam maiores gradientes de umidade dos grãos, isso ocorre devido a maior variação das condições psicrométricas do ambiente de armazenamento. 
Durante o armazenamento, ocorre deterioração em função da respiração e de outros processos metabólicos, os quais continuam ativos, ocasionando, na maioria das vezes, perdas significativas na qualidade do produto. Vanier (2010) observou que nos grãos armazenados em sistema convencional, em virtude da exposição dos grãos às trocas higroscópicas com o ambiente, houve diferença no teor de água ao longo do tempo de armazenamento.

$\mathrm{Na}$ pesquisa de Villers (2006), o armazenamento convencional, quando exposto a ambiente quente e úmido, não protegeu adequadamente o produto armazenado durante o tempo desejado e isso resultou em grandes perdas em quantidade e qualidade.

\subsection{Efeito do ambiente de armazenamento na qualidade dos grãos}

Nos países em desenvolvimento, há a necessidade de tecnologias que permitam o armazenamento de grãos a longo prazo, em condições de ambientes quentes e úmidos (WEINBERG et al. 2008).

Segundo Christensen e Kaufmann (1969), a viabilidade dos grãos oleaginosos dependente das características genéticas da espécie e dos efeitos do meio ambiente durante a sua formação, desenvolvimento, maturação, colheita e processos pós colheita.

$\mathrm{Na}$ armazenagem a conservabilidade está sujeita a fatores, como temperatura e umidade relativa do ar, que controlam a umidade e a velocidade dos processos bioquímicos dos grãos, como matéria-prima para os biocombustíveis (ZENI, 2010).

No armazenamento com temperatura ou teor de água elevadas, pode ocorrer o desenvolvimento de pragas e fungos, que danificam os grãos e alteram a qualidade tecnológica da farinha (KOCH et al. 2006).

A temperatura externa do armazenamento tem efeito direto sobre os grãos armazenados em silos. Os grãos são aquecidos pelos raios solares, os quais geram gradientes de temperatura adicional, induzindo condições favoráveis para reprodução de fungos e insetos (JIAN et al, 2009).

Com a elevação da temperatura, o ar aumenta a sua capacidade de absorver água e através de transferências de calor e de massa podem ocorrer variações no 
teor de água, tendendo ao equilíbrio higroscópico entre o produto e o ambiente (POHNDORF, 2012). Variações no teor de água dos grãos podem ocorrer ao longo do armazenamento devido à higroscopicidade, ou seja, a capacidade de sorção de água. Essas variações são forçadas por fatores externos do ambiente, principalmente pela umidade relativa e temperatura do ar.

Resende et al. (2008), realizou uma pesquisa objetivando avaliar a qualidade tecnológica dos grãos de feijão, por meio das análises do tempo de cocção, absorção de água em diferentes temperaturas, durante quatro meses de armazenamento, em condições ambientais. No entanto, observaram que o teor de água dos grãos permaneceu em equilíbrio com as condições do ar, no interior dos frascos (temperatura e umidade relativa), durante o armazenamento.

Condições de armazenamento que promovem um aumento da intensidade da respiração dos grãos são prejudiciais porque produzem mudanças nas suas propriedades físicas e químicas que os tornam inúteis para o consumo "in natura" ou processamento industrial. OLIVEIRA et al. (2007) alertam que, durante o armazenamento em silos, os grãos ficam sujeitos às alterações da temperatura ambiente, que aliadas ao teor de água dos grãos influem diretamente na ocorrência de insetos e microrganismos.

Para Baudet (2003), a deterioração do grão é um processo irreversível, não se pode impedi-la, mas é possível retardar sua velocidade com o controle das condições ambientais durante o armazenamento de forma eficiente. Bordignon (2009) afirma que, quanto maior o tempo de armazenagem, maior será o índice de acidez, em função de ações enzimáticas ou de processos oxidativos.

Assim, as condições iniciais dos grãos (teor de água e percentagem de grãos danificados), práticas de gestão (seleção do local adequado e de preparação) e características climáticas durante o armazenamento (temperatura do ar ambiente e radiação solar), permite determinar o tempo de armazenamento seguro dos grãos (BARTOSIK et al., 2008).

Existe, portanto, a necessidade de conhecimentos científicos sobre a influência e o comportamento da temperatura nas sementes armazenadas sobre a manutenção da qualidade (DEMITO, 2006). As condições desfavoráveis de armazenagem contribuem para a redução na viabilidade de sementes e perda de qualidade de grãos. 


\subsubsection{Teor de água}

Segundo Rios et al. (2003), o teor de água superior ao recomendado para o armazenamento seguro é uma das principais causas da perda das suas características tecnológicas, além de ser um fator importante no controle do processo de deterioração de grãos armazenados. Se a umidade puder ser mantida a níveis baixos, os demais fatores terão seus efeitos grandemente diminuídos.

Owens (2003) afirma que a operação de manejo de umidade é de fundamental importância para o sucesso de qualquer unidade armazenadora de grãos. $\mathrm{O}$ teor de água influencia nas características da matéria prima, no comportamento durante o armazenamento, na qualidade do produto e na viabilidade econômica.

Bertinetti, I. A. et al. (2011b), em sua pesquisa, avaliaram os efeitos da hermeticidade no armazenamento sobre parâmetros de qualidade dos grãos e do óleo de soja, durante 12 meses de armazenamento e verificou-se pelos resultados apresentados que as maiores variações no teor de água nos grãos ocorrem nos armazenados pelo sistema convencional. Nos grãos armazenados em ambiente não hermético, há maior exposição destes às condições psicrométricas do ambiente, o que é típico desse sistema. $\mathrm{O}$ grau de umidade aos 12 meses de armazenamento não se alterou em função da hermeticidade do sistema.

Bordignon (2009) cita que como há uma relação direta da umidade dos grãos com seu tempo de permanência viável no armazenamento, passou-se a procurar quais os níveis de umidade mais adequados para longos períodos de armazenamento.

Rutz (2012), avaliando os efeitos da temperatura e do tempo de armazenamento do trigo sobre parâmetros de avaliação da qualidade dos grãos e das farinhas, observou que os grãos de trigo permaneceram com o teor de água praticamente estável durante o armazenamento. Os grãos armazenados a $4^{\circ}$ e a $25^{\circ} \mathrm{C}$ mantiveram o seu teor de água até aos 90 dias, aos 135 dias perderam um pouco e mantiveram até aos 180 dias. Os grãos armazenados a $11^{\circ}$ e a $18^{\circ} \mathrm{C}$ perderam água aos 45 dias e mantiveram o teor estável até aos 180 dias. Os valores médios variaram entre 12,03 e 12,67\%, b.u.

Em condições tropicais e subtropicais, o grau de umidade é o mais importante fator na preservação da qualidade dos grãos e no desenvolvimento de fungos, uma vez que no armazenamento utilizado existe pouco ou nenhum controle da 
temperatura, a qual se encontra em níveis favoráveis ao desenvolvimento de fungos, durante quase o ano todo (LAZZARI, 1997).

A umidade de equilíbrio ou equilíbrio higroscópico é o grau de umidade dos grãos quando em equilíbrio com o ar que os envolve, sendo dependente da espécie, da variedade, do grau de maturidade e das condições prévias a que o grão foi submetido (ELIAS, 2002).

Quando a pressão de vapor da água do grão é igual ao do ambiente ao seu redor, seu grau de umidade é igual à umidade de equilíbrio. Assim, nessa condição, a umidade relativa do ar é denominada umidade relativa de equilíbrio. Quando se alcança esta condição, a taxa de transferência de água dos grãos para o ambiente é igual a taxa de transferência de água do ambiente para os grãos. Essa condição é denominada equilíbrio dinâmico (OLIIVEIRA, 2008).

Grãos armazenados a valores de umidade acima do recomendado para um armazenamento seguro sofrem degradação de proteínas, carboidratos, de fosfolipídeos, etc., produzindo compostos lipossolúveis que contaminam o óleo com impurezas que não estão usualmente presentes. Estas afetam a cor, o odor, e o sabor. Além disso, o processo de deterioração é invariavelmente acompanhado da hidrólise de triacilgliceróis.

\subsubsection{Acidez graxa}

O teste de acidez graxa, como método para avaliar a deterioração em grãos armazenados, tem na sua sensibilidade a principal vantagem. Como a formação de ácidos graxos livres nos grãos é resultante da hidrólise das gorduras, esta análise permite, além da quantificação do processo deteriorativo, acusá-lo ainda nos estágios iniciais (BIAGGIONI; BARROS, 2006).

A acidez graxa representa o estado de conservação dos grãos, envolvendo tanto aspectos químicos como microbiológicos (ORTOLAN, 2006). Segundo Elias (1997), o aumento dos valores de acidez está relacionado diretamente com a atividade catalítica das lipases produzidas por microrganismos e/ou pelo próprio grão, ocasionando o desenvolvimento da rancidez lipídica, a qual se intensifica com a deterioração dos grãos no armazenamento, sendo o aumento utilizado como parâmetro de conservabilidade. 
Deliberali, et al. (2010), estudaram a influência dos processos de secagem estacionário e intermitente e do período de armazenamento de doze meses na qualidade tecnológica de grãos de trigo, obtiveram resultados de acidez graxa que se mostrou diferente significativamente durante o período de armazenamento estudado, em função do processo de secagem e do tipo de colheita dos grãos de trigo.

O teor de ácidos graxos livres expressa a quantidade de ácidos graxos liberados da estrutura do glicerol e está associado à rancidez hidrolítica (DHINGRA et al. 1998). Soares et. al. (2005), avaliando o índice de ácidos graxos livres em grãos de soja, não encontraram diferença estatística significativa até os 60 dias após o armazenamento, no entanto a partir dos 90 dias constataram diferença significativa apesar dos grãos não terem um comportamento padrão.

Nithya et al. (2011), estudando o armazenamento de grãos de trigo duro, também verificaram que a acidez graxa das amostras aumentou com o aumento da temperatura e do período de armazenamento.

Valores elevados de ácidos graxos livres significam não apenas maiores perdas no processo de refino, mas, também, qualidade inferior do óleo que, por sua vez, indica baixa qualidade da matéria-prima, manejo inadequado ou falta de controle durante o armazenamento (O'BRIEN, 2004). Diante do exposto, a acidez graxa é utilizada como indicador de qualidade durante o armazenamento de grãos (MUIR, 2000).

\subsubsection{Condutividade Elétrica}

O teste de condutividade elétrica avalia, indiretamente, o grau de estruturação das membranas celulares, por meio da determinação da quantidade de íons lixiviados em uma solução de embebição. Essa quantidade é inversamente relacionada à integridade das membranas celulares e ao vigor de sementes, ou seja, sementes de menor potencial fisiológico liberam maior quantidade de lixiviados durante a embebição (LIMA, 2008).

Ledâ et al. (2009), avaliando as principais alterações qualitativas na soja armazenada em silos-bolsa e do óleo bruto extraído desse material, observaram aumento significativo da condutividade elétrica da soja com $17,4 \%$ de teor de água, em decorrência da interação entre camadas do silo tipo bolsa e período de armazenamento. No 
entanto, $\mathrm{O}$ aumento ocorreu principalmente a partir do terceiro mês de armazenamento. Não foi verificada variação significativa desse parâmetro no material armazenado com $13,3 \%$ de teor de água durante o período de armazenamento, indicando menor deterioração dos mesmos.

Costa et al. (2012), avaliando o armazenamento de frutos de crambe em três condições: condição ambiente $\left(26 \pm 3{ }^{\circ} \mathrm{C} ; 55 \pm 12 \%\right.$ Umidade Relativa UR), câmara refrigerada do tipo B.O.D. $\left(5 \pm 1{ }^{\circ} \mathrm{C} ; 79 \pm 5 \%\right.$ UR) e câmara climatizada com condicionador de ar $\left(18 \pm 1{ }^{\circ} \mathrm{C} ; 53 \pm 7 \%\right.$ UR) durante o período de 12 meses, observaram que o crambe armazenado em câmara refrigerada apresentou menores valores de condutividade elétrica ao longo do armazenamento, sendo identificado diferença estatística significativa a partir do $6^{\circ}$ mês de armazenamento, o que indica menor lixiviação de eletrólitos, e grãos de melhor qualidade.

Oliva (2010), em seu trabalho, avaliou o efeito da secagem natural e artificial sobre a qualidade de sementes de crambe no decorrer do armazenamento. Aos 6 meses de armazenamento, o menor valor obtido na condutividade elétrica foi no tratamento de secagem na planta. Da mesma maneira, apesar de não ocorrer diferença estatística, este tratamento obteve o menor valor aos 8 meses de armazenamento, no qual a secagem à sombra apresentou o valor estatisticamente mais alto. A embebição mais rápida pelas sementes recentemente colhidas pode ser uma das causas do valor de condutividade elétrica mais alto no tempo zero de armazenamento.

Ao avaliar a qualidade da soja armazenada em diferentes combinações de teores de água e temperatura, Alencar et al. (2008) observaram que a interação entre teor de água, temperatura e período de armazenamento demonstrou efeito significativo sobre a condutividade elétrica da solução que continha os grãos de soja armazenados com teores de água de 11,2, 12,8 e 14,8\% b.u. nas temperaturas de 20, 30 e $40{ }^{\circ} \mathrm{C}$.

Segundo Faroni et al. (2005), quanto maior a temperatura e o período de armazenamento, maior a condutividade elétrica da solução que continha os grãos, indicando maior deterioração da membrana celular desses grãos, devido à maior lixiviação de eletrólitos do interior das células para o meio, gerando maiores valores de condutividade elétrica. 


\subsubsection{Cor do grão}

Um importante aspecto considerado crítico e determinante durante a comercialização dos grãos é a aparência. Durante o armazenamento, os grãos são propícios a alterações físicas, químicas e biológicas. Dentre as alterações está a coloração do tegumento. Hou \& Chang (2004), relatam que o armazenamento provoca o escurecimento dos grãos de soja.

Alencar et al. (2009), estudando o comportamento de grãos de soja armazenados com diferentes teores de água (11,2, 12,8 e 14,8\%, b.u.) em diferentes temperaturas $\left(20,30\right.$ e $\left.40^{\circ} \mathrm{C}\right)$ com avaliações a cada 45 dias ao longo de 6 meses, verificaram que os valores da diferença de cor das amostras aumentaram no decorrer do período de armazenamento e não ocorreram muitas variações entre os grãos armazenados a 20 e a $30^{\circ} \mathrm{C}$, com teor de água de 11,2 e de $12,8 \%$, b.u. Já em todos os tratamentos a $40^{\circ} \mathrm{C}$ e também nos com teor de água de $14,8 \%$, b.u., obtiveram uma variação considerável na diferença de cor.

A alteração da cor resulta da oxidação natural dos pigmentos ocorrida durante o período de armazenamento, sendo que os valores variam com a extensão do período de armazenamento e o envelhecimento (ORTOLAN et al., 2010).

Para Júnior e Corrêa (2003), que avaliaram o efeito do préprocessamento, por via seca e via úmida, sobre a cor dos grãos de café beneficiados, durante o armazenamento, a intensidade das cores verde e azul dos grãos de café foi afetada durante o armazenamento, independentemente do tipo de pré-processamento empregado.

O escurecimento do tegumento de grãos tem sido um sério problema encontrado em muitos grãos armazenamentos, especialmente em alguns grãos oleaginosos (Junk-Knievel et al., 2008). Deterioração também tem profunda influência sobre as propriedades físicas de grãos armazenados, como textura, massa volumétrica aparente, e cor (Nasar-Abbas et al., 2009).

\subsubsection{Rendimento de óleo no grão}

Ao estudar os sistemas umidades de colheita e métodos de secagem em função do período de armazenamento sobre a conservabilidade e qualidade tecnológica de trigo, Elias et al. (2008) relataram que a redução no teor de óleo dos grãos armazenados 
é atribuída ao desenvolvimento fúngico, à atividade de enzimas lipases e lipoxigenases, e à auto oxidação das gorduras na presença de oxigênio.

A redução no teor de lipídios e o aumento no teor de ácidos graxos livres estão diretamente correlacionados com a velocidade e intensidade do processo deteriorativo dos grãos. A avaliação desses índices constitui-se em eficiente parâmetro para o controle da conservabilidade de grãos durante o armazenamento (MARINI et al., 2005).

Oliveira et al. (2007), estudando os efeitos da temperatura e do tempo de armazenamento nas características tecnológicas do óleo de soja para matériaprima adequada à produção de biodiesel, obtiveram redução do rendimento de óleo de nos grãos de soja armazenados, ao longo de oito meses. Nos grãos armazenados em ambiente controlado, a redução foi significativamente menor do que no óleo extraído dos grãos armazenados em ambiente sem controle de temperatura.

A velocidade das alterações dos lipídios depende da umidade, da temperatura e do tempo de armazenamento (MARINI et al., 2005b).

\subsection{Qualidade do óleo durante processo de armazenagem}

Para se obter sucesso na produção de biodiesel, é necessário preservar a matéria prima para a extração do óleo, dessa maneira as operações de póscolheita devem ser realizadas adequadamente.

Estudando o efeito das condições ambientais (ambiente com temperatura controlada de $17^{\circ} \mathrm{C}$ e ambiente sem controle de temperatura) e do tempo de armazenamento de soja sobre a qualidade do óleo para a produção de biodiesel, Oliveira et. al. (2007) encontraram diminuição no rendimento de extração de óleo com oito meses de armazenamento e aumento significativo no teor de acidez, no mesmo período. Ainda, com oito meses de armazenamento, o índice de peróxido do óleo aumentou, contudo, esse índice foi maior no ambiente não controlado.

Analisando o efeito do período de armazenamento dos grãos de soja na qualidade do óleo bruto, Alencar (2006) encontrou aumento significativo do índice de ácidos graxos livres no decorrer do armazenamento, com grãos com teor de água de $14,8 \%$ b.u.

Com o objetivo de avaliar o efeito do armazenamento na qualidade do óleo bruto de soja, Alencar et. al. (2010) concluíram que a combinação de alta umidade e temperatura durante o armazenamento acelera o processo de deterioração dos grãos, 
podendo resultar em perda no rendimento do óleo. O armazenamento de grãos de soja com umidade até $15 \%$ (b.u.) a $20^{\circ} \mathrm{C}$ não afeta a qualidade do óleo, enquanto o óleo bruto armazenado até $13 \%$ (b.u.) a $30^{\circ} \mathrm{C}$ mantém a sua qualidade satisfatória por 180 dias. Não é possível se obter óleo de soja nos padrões exigidos para comercialização com grãos de soja armazenados com umidade de $11 \%$ (b.u.) a $40^{\circ} \mathrm{C}$.

Ao avaliar a qualidade do óleo de grãos de soja armazenados em silos tipo bolsa, Faroni et al. (2009) encontraram que, em grãos armazenados com 17,4 e $13,3 \%$ de umidade, não houve variação ao longo do armazenamento em relação ao teor de ácidos graxos livres e, ainda, que os valores de ácidos graxos livres de grãos de soja armazenados por 180 dias ficaram em 1,05\% para grãos armazenados via úmida e $0,59 \%$ via seca, mantendo-se, assim, valores abaixo do limite estabelecido pela ANVISA (1999) que é de $2 \%$.

O conteúdo de água em Bio-óleos geralmente varia na faixa de 15 a $30 \%$ em peso, dependendo da umidade inicial das matéias-primas e das condições de pirólise. A presença de água tem efeitos negativos e positivos sobre o armazenamento e utilização de bio-óleos. Por um lado, ela facilita a separação de fases de bio-óleos, atrasa a ignição, e reduz as taxas de combustão durante o processo. Por outro lado, ajuda a reduzir e a viscosidade e facilitar a atomização (Qiang et al. 2009).

Com o objetivo de avaliar a qualidade do óleo bruto extraído dos grãos de soja armazenados em silos bolsa com teores de água de 12 e 17\% nas temperaturas de 15,25 e $35^{\circ} \mathrm{C}$, Silva et al. (2010) observaram que o percentual de ácidos graxos livres e o índice de peróxidos do óleo bruto extraído dos grãos armazenados hermeticamente mantiveram-se abaixo do limite imposto para comercialização. Concluíram que a armazenagem de grãos de soja em silos tipo bolsa não afeta a qualidade do óleo bruto extraído.

Oliveira et al. (2010) estudando o efeito do tempo e do armazenamento refrigerado de grãos de soja sobre a qualidade do óleo, com ambiente refrigerado com $17^{\circ} \mathrm{C}$ aos quatro e oito meses de armazenamento, concluíram que esse método de armazenamento provoca menores reduções no teor do óleo, menores índices de acidez e de peróxido em óleo de soja bruto.

Estudando o efeito do armazenamento na qualidade de sementes de amendoim, Castro (2010) não encontrou diferença estatística significativa na extração do óleo entre as cultivares avaliadas, encontrou diferença significativa na extração do óleo em 
sementes armazenadas com presença de fungos a $30^{\circ} \mathrm{C}$ e umidade relativa de $70 \%$ apresentando maior teor de óleo do que sementes armazenadas com $20^{\circ} \mathrm{C}$ e $50 \%$ U.R. com ausência de fungos.

Em estudo realizado para verificar as características físicoquímicas em macaúba [Acrocomiaaculeata(Jacq.) Lodd. ex Mart] para produção de biodiesel, Amaral (2007) concluiu que o armazenamento do óleo da polpa e da amêndoa da macaúba interfere diretamente em suas propriedades qualitativas. Ainda encontrou variação quanto ao processamento do fruto, pois na polpa o índice de acidez foi de $59,9 \mathrm{mg}$ $\mathrm{KOH} \mathrm{g}^{-1}$ e na amêndoa foi de $12,8 \mathrm{mg} \mathrm{KOH} \mathrm{g}^{-1}$, o índice de peróxidos também foi maior na polpa, onde apresentou 27,28 meq $\mathrm{kg}^{-1}$ e na amêndoa essa valor foi de $15,57 \mathrm{meq} \mathrm{kg}^{-1}$. 


\section{MATERIAL E MÉTODOS}

O trabalho foi instalado e desenvolvido na Fazenda Experimental Lageado na Universidade Estadual Paulista "Júlio de Mesquita Filho" - UNESP, Faculdade de Ciências Agronômicas - FCA, Câmpus de Botucatu/SP.

O município de Botucatu encontra-se em um local com coordenadas geográficas Latitude - $22^{\circ} 52^{\prime}$ 20” S Longitude - 48 $26^{\circ} 37^{\prime}$ ' W Greenwich, altitude média de 770 metros, declividade média de 4,5\% e clima subtropical, com verões quentes e úmidos e invernos frios e secos.

Foram utilizadas, para a semeadura, sementes de crambe da cultivar FMS Brilhante. O campo de produção dos grãos consistiu numa área de 0,5 ha, instalado na Fazenda Experimental Lageado.

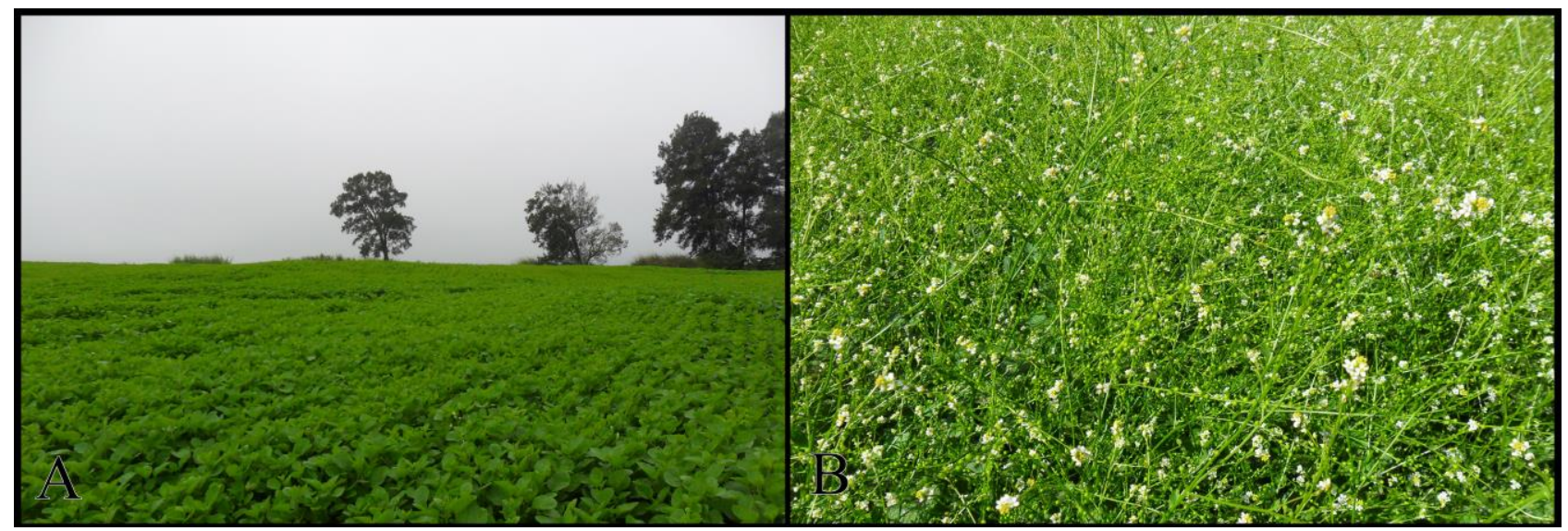

Figura 1. (A) Área experimental de produção de crambe e (B) foto da planta com flores. 
O teor de água foi monitorado a partir do ponto de maturidade fisiológica, até que os grãos atingissem teor de água abaixo de $10 \%$ quando procedeu-se a colheita mecânica (Figura 2).

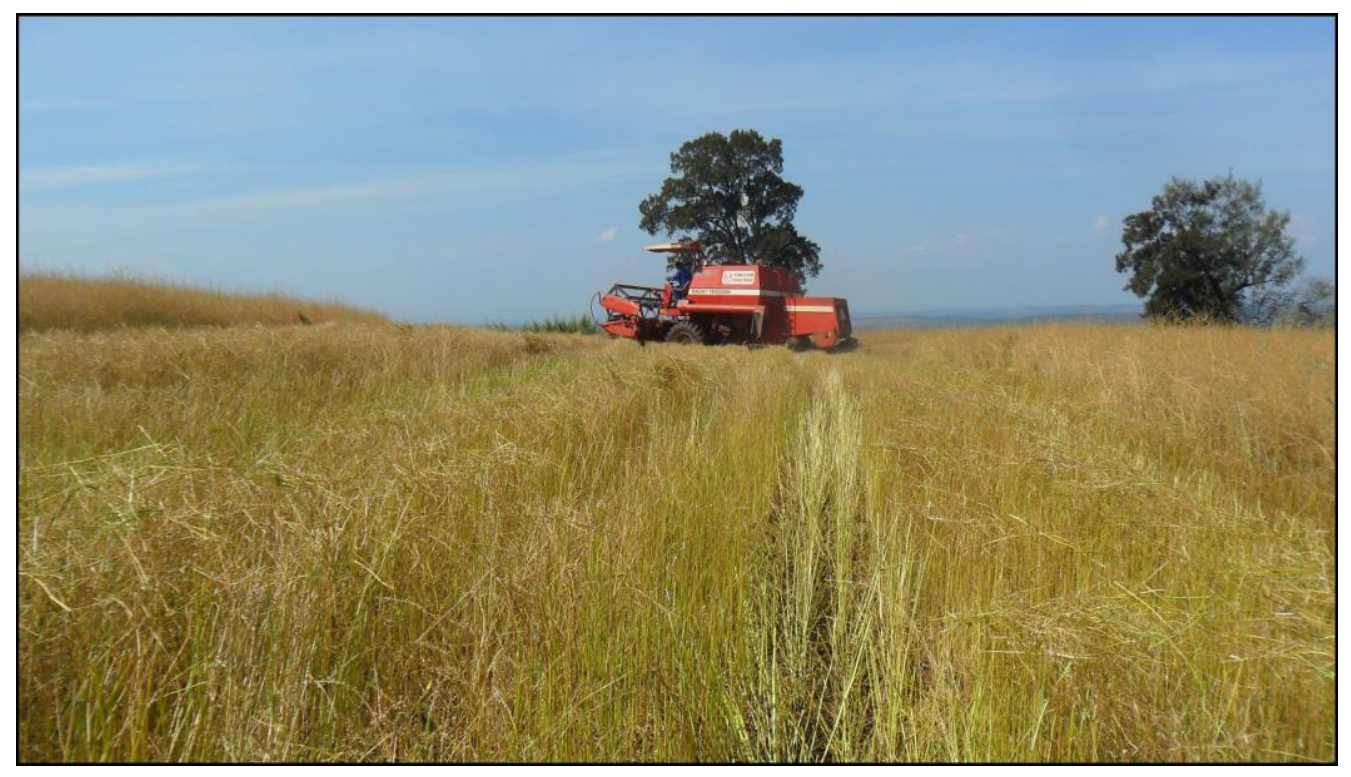

Figura 2. Colheita mecânica de crambe seco naturalmente na planta, na área experimental de produção de crambe, na Fazenda Lageado, FCA, UNESP, Botucatu-SP.

Os tratamentos experimentais foram conduzidos no Laboratório de Processamento de Produtos Agrícolas e na área experimental (estufa) pertencente ao Departamento de Engenharia Rural.

A extração do óleo foi realizada na Faculdade de Tecnologia de Botucatu (FATEC), por meio de prensa mecânica. Amostras do óleo foram então encaminhadas para caracterizações físico-químicas, para o Centro de Monitoramento e Pesquisada Qualidade de Combustíveis, Petróleo e Derivados (CEMPEQC), junto ao Instituto de Química - UNESP/Campus de Araraquara.

\subsection{Armazenamento dos grãos}

Os grãos secos na planta foram armazenados por um período de doze meses, com avaliações qualitativas realizadas no momento do armazenamento (tempo zero), com seis meses e ao final de um período de doze meses. 
Antes do armazenamento, os grãos foram acondicionados em dois tipos de embalagens: mini-bolsas impermeáveis (embalagem hermética) e sacaria de ráfia (testemunha).

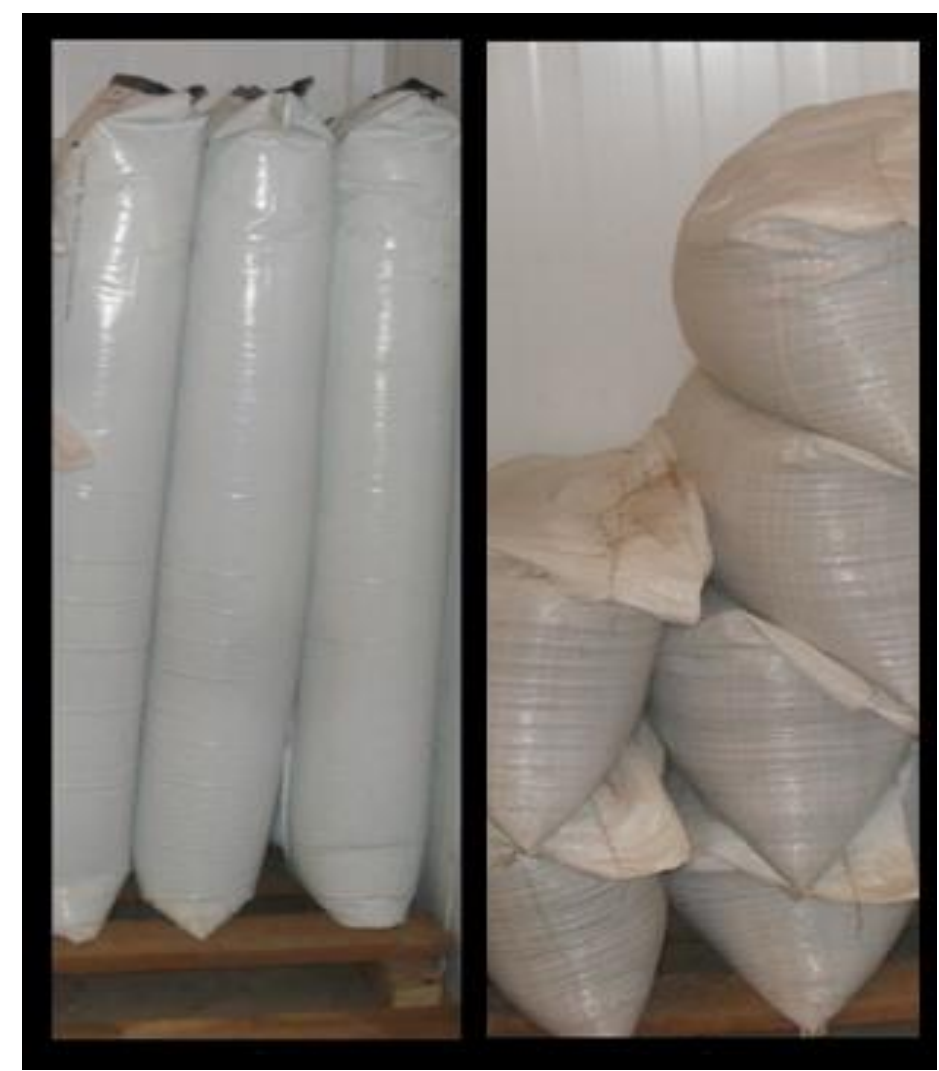

Figura 3. Embalagens mini-bolsas herméticas e sacaria convencional.

A fim de investigar os impactos de diferentes condições de armazenamento sobre qualidade dos grãos e dos óleos extraídos, os grãos embalados foram mantidos em três ambientes:

a) Sala climatizada mantida com umidade relativa constante (próxima de $80 \%$ ) e com alternância de temperatura $\left(30^{\circ} \mathrm{C}\right.$ por 16 horas e $25^{\circ} \mathrm{C}$ por 8 horas), simulando uma condição de estresse por alta temperatura e elevada umidade relativa. 


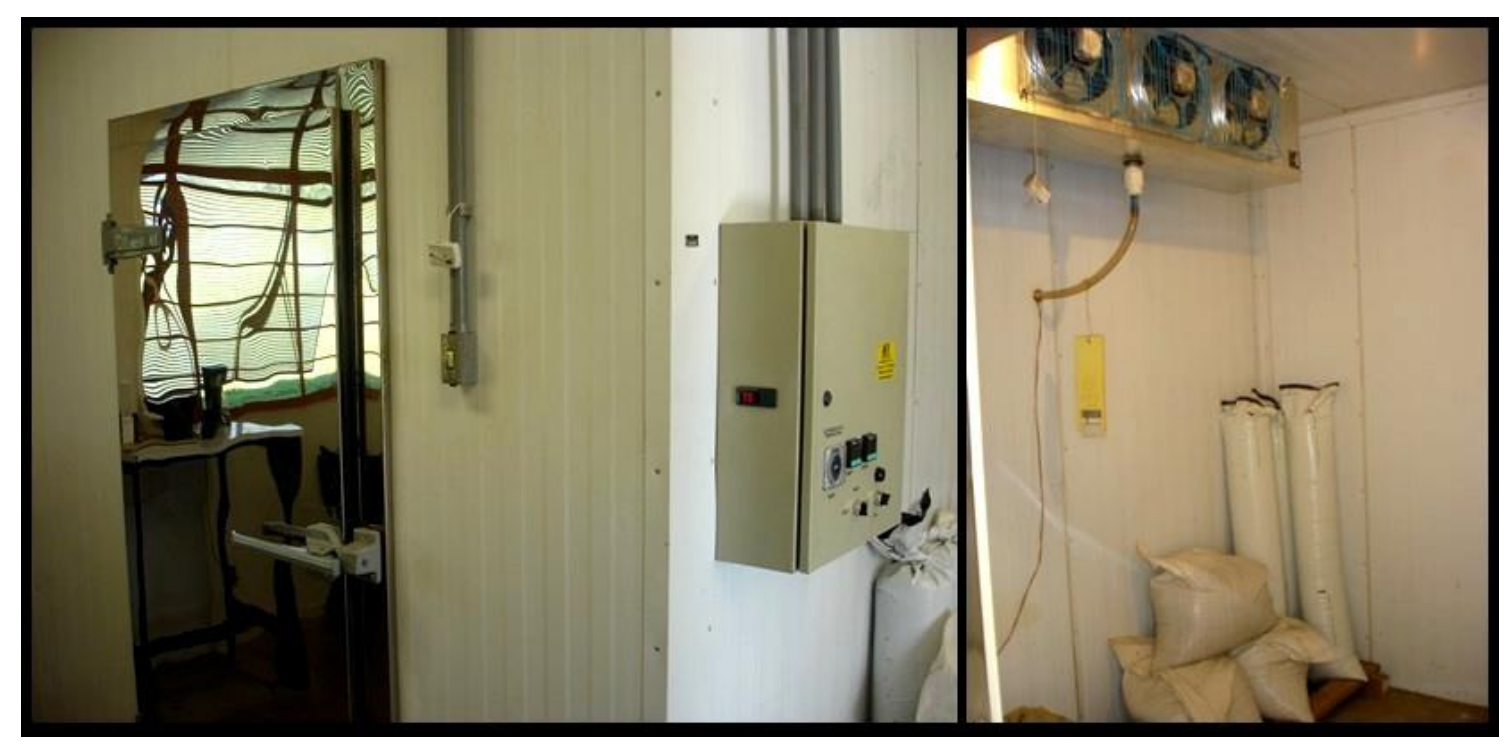

Figura 4. Sala climatizada com ambiente controlado.

b) Estufa agrícola, sem controle de ambiente, simulando uma condição de "armazenagem a céu aberto" com estresse por alta temperatura e elevada insolação.

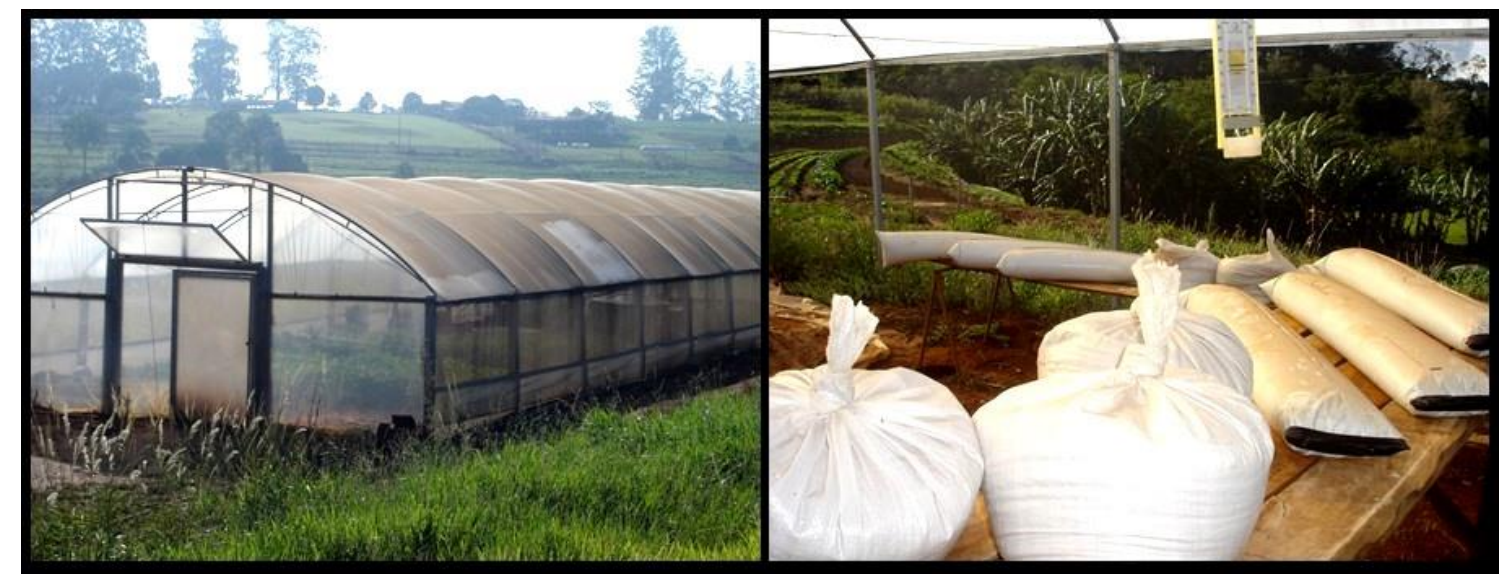

Figura 5. Estufa agrícola sem controle de ambiente

c) sala não climatizada, sem controle de ambiente, simulando uma condição de "armazém convencional". 


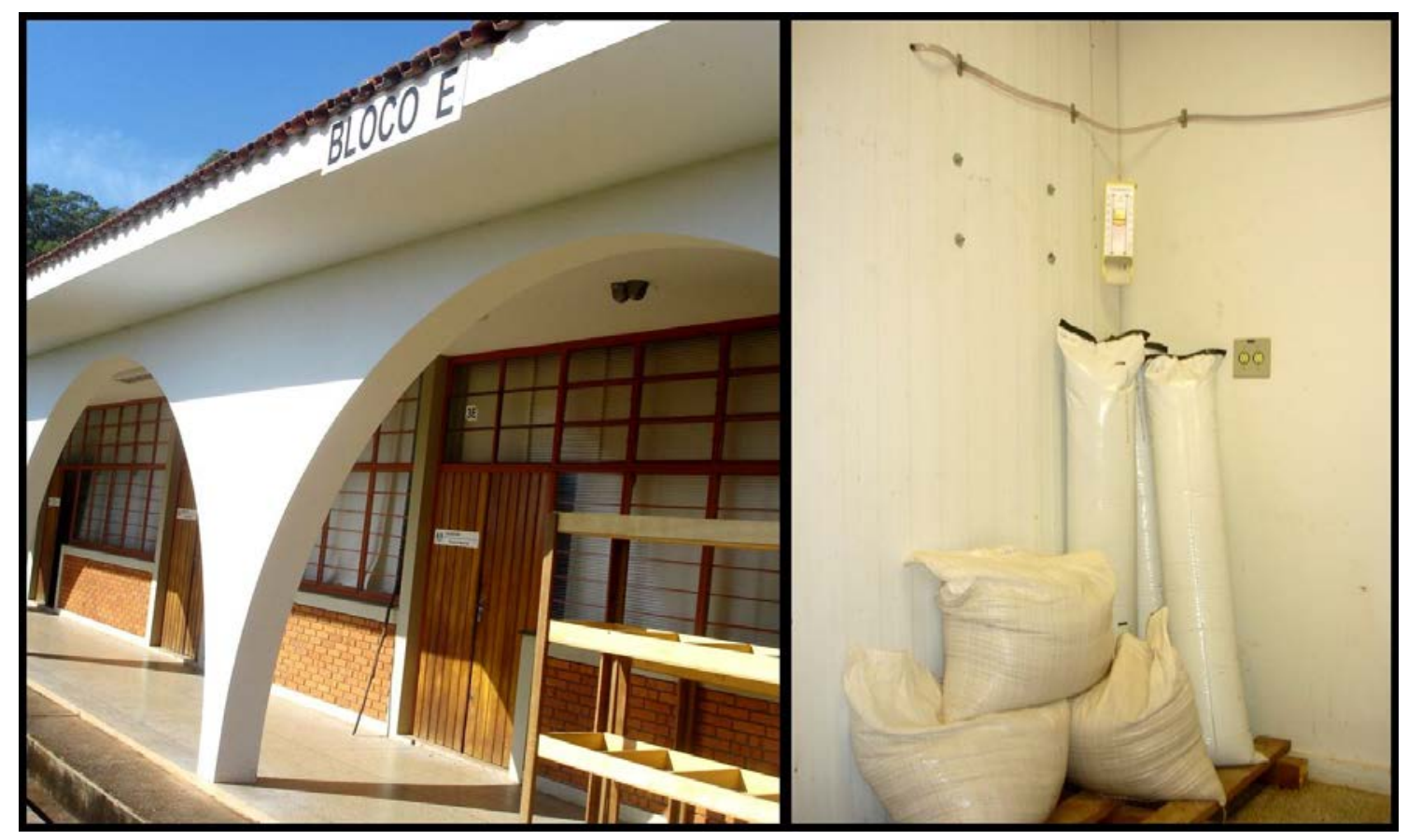

Figura 6. Sala não climatizada, sem controle de ambiente

Os silos bolsas, medindo $0,30 \mathrm{~m}$ de diâmetro por $1,30 \mathrm{~m}$ de comprimento, com capacidade para $12 \mathrm{~kg}$ de crambe, são sacos de polietileno de alta resistência, utilizando filme extrusado com três camadas na sua fabricação e apresentando a face interna preta e a externa branca. Obtém-se, assim, além da hermeticidade, obstrução total à passagem de luz (face preta), evitando a proliferação de fungos, e reflexão da luz com maior intensidade (face branca), causando menor aquecimento na superfície do produto armazenado, aumentando, desta forma, o seu aproveitamento e diminuindo as perdas nutricionais.

Os valores da umidade e da temperatura do ar foram registrados diariamente, em todos os ambientes de armazenagem, por meio de um termo-higrógrafo. Depois de concluído o tempo de armazenamento dos grãos, foram realizadas as análises de qualidade.

\subsection{Delineamento experimental e análises estatísticas}

O delineamento experimental foi inteiramente casualizado, com dois tipos de embalagens, três condições de ambiente e três períodos de armazenamento, consistindo em um fatorial triplo $2 \times 3 \times 3$, com três repetições, totalizando 18 tratamentos e 
54 parcelas. Os resultados serão submetidos à análise de variância e as médias comparadas pelo teste de " $\mathrm{t}$ " $(\mathrm{p}<0,05)$.

\subsection{Análises dos grãos}

\subsubsection{Teor de água dos grãos}

O teor de água dos grãos foi determinado pelo método da estufa a $105 \pm 3^{\circ} \mathrm{C}$, por 24 horas, utilizando-se três repetições de $4,5 \pm 0,5$ gramas (BRASIL, 2009), e os resultados foram expressos em porcentagem (base úmida).

\subsubsection{Acidez graxa}

A avaliação da acidez graxa foi realizada conforme procedimento determinado pela AACC (1995) e o resultado do teor de ácidos graxos livres foi dado pela Equação:

$$
\mathrm{AG}=[(\mathrm{V} \times 100) / \mathrm{PS}]
$$

onde:

PS: peso seco da amostra, em g;

$\mathrm{V}$ : volume gasto de $\mathrm{KOH}$ na titulação (extrato + indicador), em mL;

AG: acidez graxa (mL de $\mathrm{KOH} / 100 \mathrm{~g}$ de $\mathrm{MS})$.

\subsubsection{Condutividade elétrica}

Para a determinação da condutividade elétrica, foram utilizadas 100 sementes, pesadas e colocadas em copo com capacidade para $200 \mathrm{~mL}$, juntamente com 50 $\mathrm{mL}$ de água deionizada, e mantidas em câmara à $20^{\circ} \mathrm{C}$ por 16 horas, de acordo com a metodologia utilizada para canola (WAGNER; DUCOURNAU, 2007).

\subsubsection{Rendimento de óleo}

O rendimento de óleo dos grãos de crambe foi realizado pelo método químico, de extração por solvente (SOXHLET). Essa análise foi realizada pelo Centro de Raízes e Amidos Tropicais (CERAT), da Faculdade de Ciências Agronômicas, Universidade Estadual Paulista "Júlio de Mesquita Filho", Botucatu-SP.

$\mathrm{Na}$ extração por Soxhlet, o óleo foi obtido por meio de extração com solvente com ponto de ebulição próximo a $70^{\circ} \mathrm{C}$, sendo hexano o mais utilizado, o 
qual dissolve com facilidade o óleo sem agir sobre os outros componentes do grão (GOMES JR., 2010).

\subsubsection{Cor dos grãos}

A determinação da cor dos grãos foi realizada pelo sistema de notação de cores de Munsell (1976), sob luz natural (luz do dia), por um único observador. De cada amostra obtida pelos métodos de armazenagem, foram retiradas aleatoriamente 50 grãos, e suas cores foram comparadas com as cores da carta de Munsell. Após a avaliação visual os resultados obtidos foram expressos em "Hue" (tonalidade ou matiz, determinadas pelo comprimento de onda), "Value" (valor, indica brilho ou intensidade luminosa) e "Chroma" (saturação de cor).

Para este estudo, a carta utilizada que indica o "Hue" foi a $2.5 \mathrm{Y}$. Na vertical, as cores tornam-se sucessivamente mais escuras, da parte superior para a parte inferior de cada carta, de forma visível e equivalente de uma etapa para a outra. Na parte horizontal, as cores aumentam em saturação ("Chroma”), da esquerda para a direita, sendo sua escala indicada na parte inferior. Na escala vertical, à esquerda da carta, é indicada a notação valor ("Value"), conforme mostrado na Figura 7.

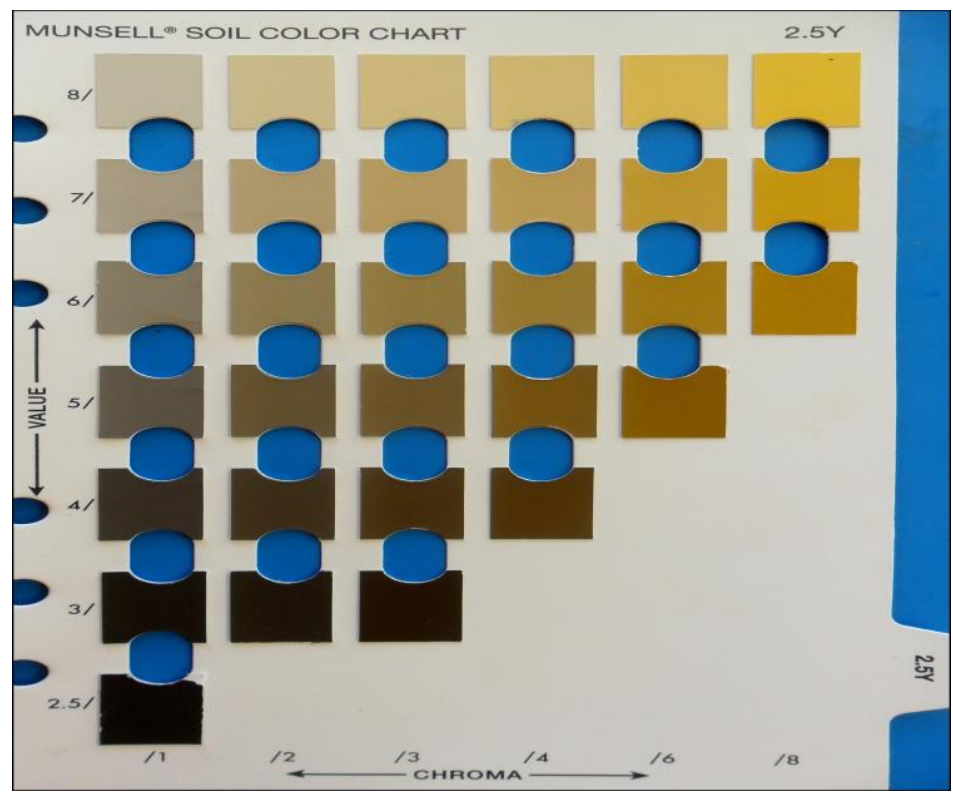

Figura 7: Carta de Munsell utilizada na classificação visual da porcentagem de grãos escurecidos de crambe (MUNSELL, 1976). 
Os grãos de crambe obtidos pelos diferentes métodos de armazenamento foram classificados em "Values", que variaram de 8 ao 6, e em "Chroma" que variou de 4 a 8 . Dentro desse parâmetro de avaliação, os grãos que apresentaram "Chroma" 4, independente da notação "Value" foram considerados escurecidos. Dessa maneira, a porcentagem de grãos escurecidos foi obtido considerando-se qualquer nuance da cor amarela (Figura 8).

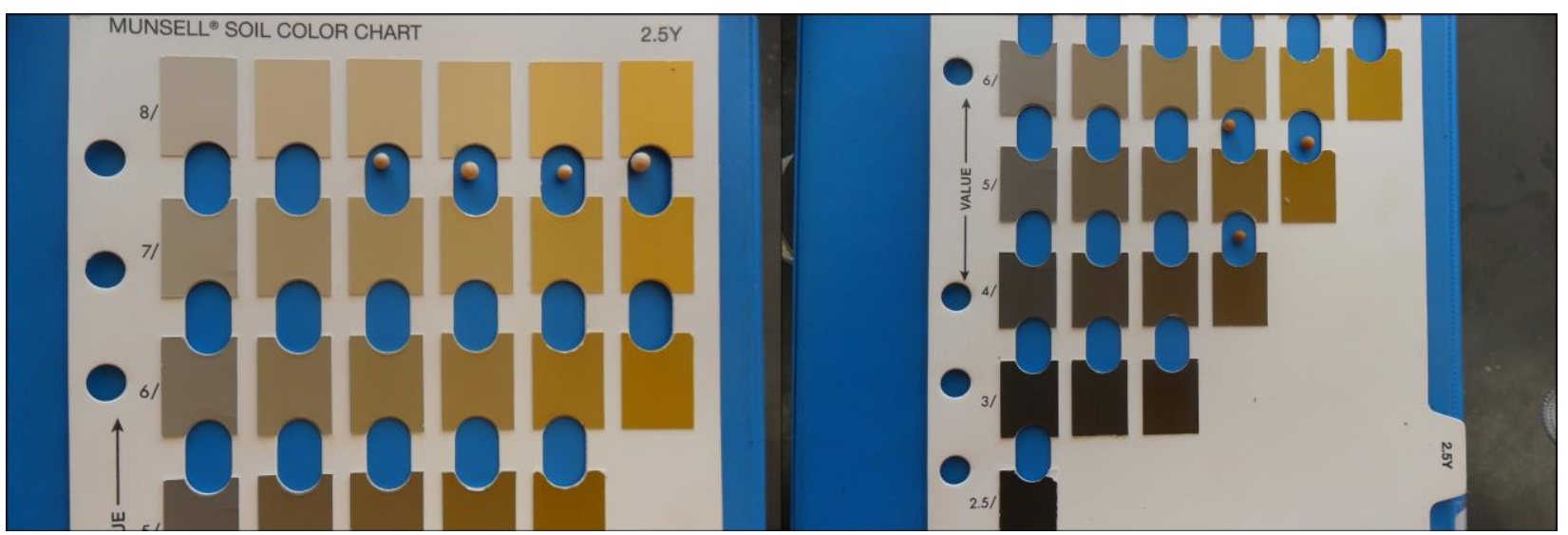

Figura 8. Exemplo de classificação de grãos de crambe, segundo a carta de Munsell (MUNSELL, 1976).

\subsection{Análise do óleo bruto}

\subsubsection{Teor de água}

A análise do teor de água no óleo foi realizada de acordo com a metodologia descrita na ASTM D 2709 (Standard Test Method for Waterand Seiment in Middle Distillate Fuelsby Centrifuge), que determina que 0,01L do óleo seja centrifugado com rotação de $2,2 \times 10^{3} \mathrm{rpm}$ por um tempo médio $6,0 \times 10^{2} \mathrm{~s}$ em tubo próprio calibrado para a realização das análises (FERNANDES et al., 2009).

\subsection{2 Índice de iodo}

A análise do índice de iodo foi realizada segundo as normas AOCS (1993), Método Cd1b-87. O índice de iodo foi calculado pela equação:

$$
\mathrm{II}=(\mathrm{Vb}-\mathrm{Va}) * \mathrm{f} * 1,27
$$

onde:

$\mathrm{II}$ = massa de iodo absorvido por $100 \mathrm{~g}$ da amostra, $\mathrm{g}$;

$\mathrm{Vb}=$ volume da solução de $\mathrm{Na}_{2} \mathrm{~S}_{2} \mathrm{O}_{3} 0,1 \mathrm{~N}$ gasto na titulação do branco, $\mathrm{mL}$;

$\mathrm{Va}=$ volume da solução de $\mathrm{Na}_{2} \mathrm{~S}_{2} \mathrm{O}_{3} 0,1 \mathrm{~N}$ gasto na titulação da amostra, mL; 
$\mathrm{f}=$ fator de correção da solução titulante; e

$\mathrm{m}=$ massa da amostra, $\mathrm{g}$.

\subsection{3 Índice de acidez}

A determinação de ácidos graxos livres foi feita de acordo com as normas AOCS (1993), Método Ca 5a-40. O percentual de ácidos graxos livres (AGL), expressa em \% de ácido oléico, foi calculado através da equação:

$$
\mathrm{AGL}=(\mathrm{Va}-\mathrm{Vb}) * \mathrm{~N} * \mathrm{f} * 28,2
$$

em que:

$\mathrm{Va}=$ volume de $\mathrm{NaOH} 0,01 \mathrm{~N}$ gasto para a amostra, $\mathrm{mL}$;

$\mathrm{Vb}=$ volume de $\mathrm{NaOH} 0,01 \mathrm{~N}$ gasto para o branco, $\mathrm{mL}$;

$\mathrm{N}$ = normalidade da solução de $\mathrm{NaOH}$;

$\mathrm{f}=$ fator de correção da solução de $\mathrm{NaOH}$; e

$\mathrm{m}=$ massa da amostra, $\mathrm{g}$.

\subsubsection{Massa específica a $20^{\circ} \mathrm{C}$}

A massa específica a $20^{\circ} \mathrm{C}$ foi obtida por meio da metodologia descrita na ASTM D-7042 (Standard Test Method for Dynamic Viscosity and Density of Liquids by Stabinger Viscometer).

\subsubsection{Viscosidade cinemática a $40^{\circ} \mathrm{C}$}

A viscosidade cinemática a $40^{\circ} \mathrm{C}$ foi realizada de acordo com a metodologia descrita na ASTM D-7042 (Standard Test Method for Dynamic Viscosity and Density of Liquids by Stabinger Viscometer). 


\section{RESULTADOS E DISCUSSÃO}

\subsection{Caracterização das condições do armazenamento}

Durante o armazenamento dos grãos de crambe, os valores de temperatura $\left(\mathrm{T}^{\circ} \mathrm{C}\right)$ e umidade relativa (UR \%) do ar variaram nos ambientes analisados, com médias (Câmara Climatizada T 32, $5^{\circ} \mathrm{C} / \mathrm{UR} 82 \%$ ), (Testemunha T 25, ${ }^{\circ} \mathrm{C} / \mathrm{UR} 65,4$ \%) e (Estufa Agrícola T $25,9^{\circ} \mathrm{C} / \mathrm{UR} 72,8 \%$ ) ao longo dos 12 meses. A variação desses parâmetros durante o armazenamento contribuiu com alterações observadas através das análises de qualidade realizadas nos grãos e no óleo bruto extraído, submetidos aos diferentes métodos de armazenagem.

As condições ambiente Estufa Agrícola e Testemunha apresentaram maiores mudanças na temperatura e umidade relativa do ar, que podem ser atribuídas às mudanças nos regimes térmicos associados com as mudanças das estações. Embora haja influencia das condições de armazenamento e do tempo, os valores obtidos a partir das análises de qualidade não apresentam comportamento definitivo (COSTA et al. 2013). 


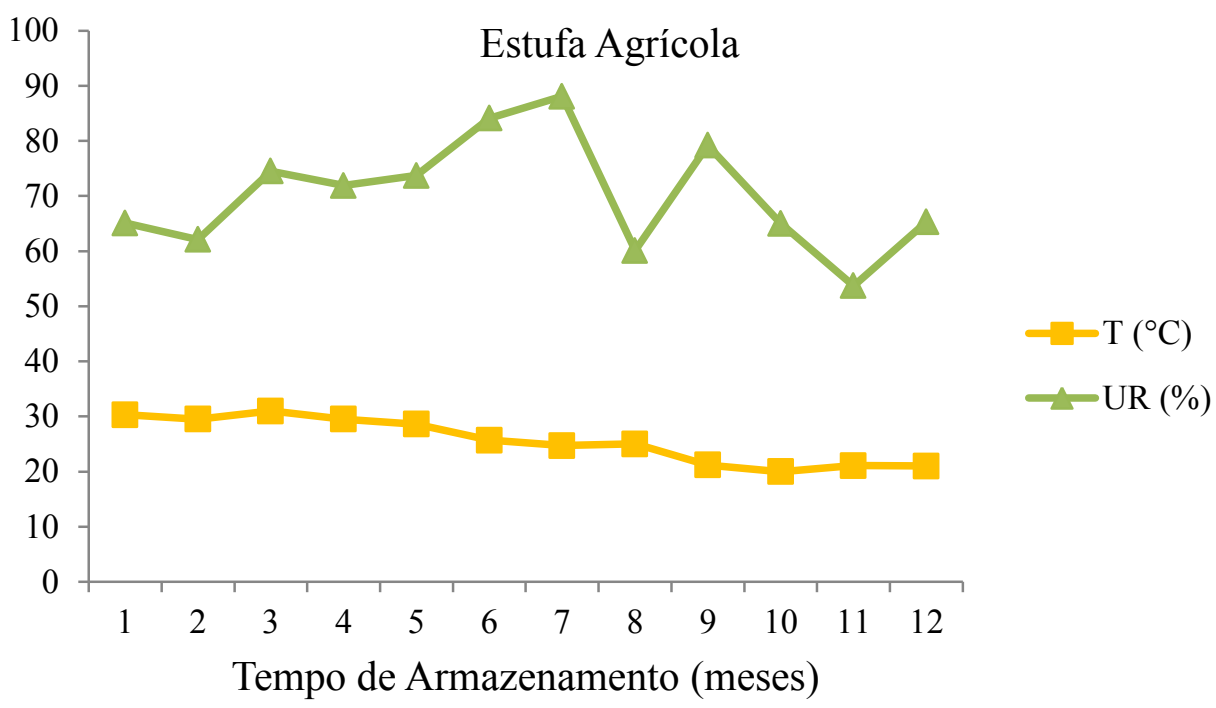

Figura 9. Valores médios mensais da temperatura $\left({ }^{\circ} \mathrm{C}\right)$ e umidade relativa do ar $(\%)$ na estufa agrícola durante o armazenamento dos grãos de crambe.

Nos primeiros 6 meses (0-6), entre os ambientes sem controle analisados, a Estufa Agrícola apresentou as maiores médias de temperatura $\left(29,1{ }^{\circ} \mathrm{C}\right)$, em função do elevado índice de insolação e as maiores médias de umidade relativa do ar (72\%) devido ao período de chuvas da região (novembro - março). Nos últimos 6 meses (6-12), foi registrado decréscimo contínuo dos valores médios de temperatura e umidade relativa do ar, que apresentaram as menores médias $\left(22,17^{\circ} \mathrm{C}\right)$ e $(68,57 \%)$, em relação aos outros ambientes de armazenamento, devido às condições climáticas da região, nesse período do ano (abril - setembro).

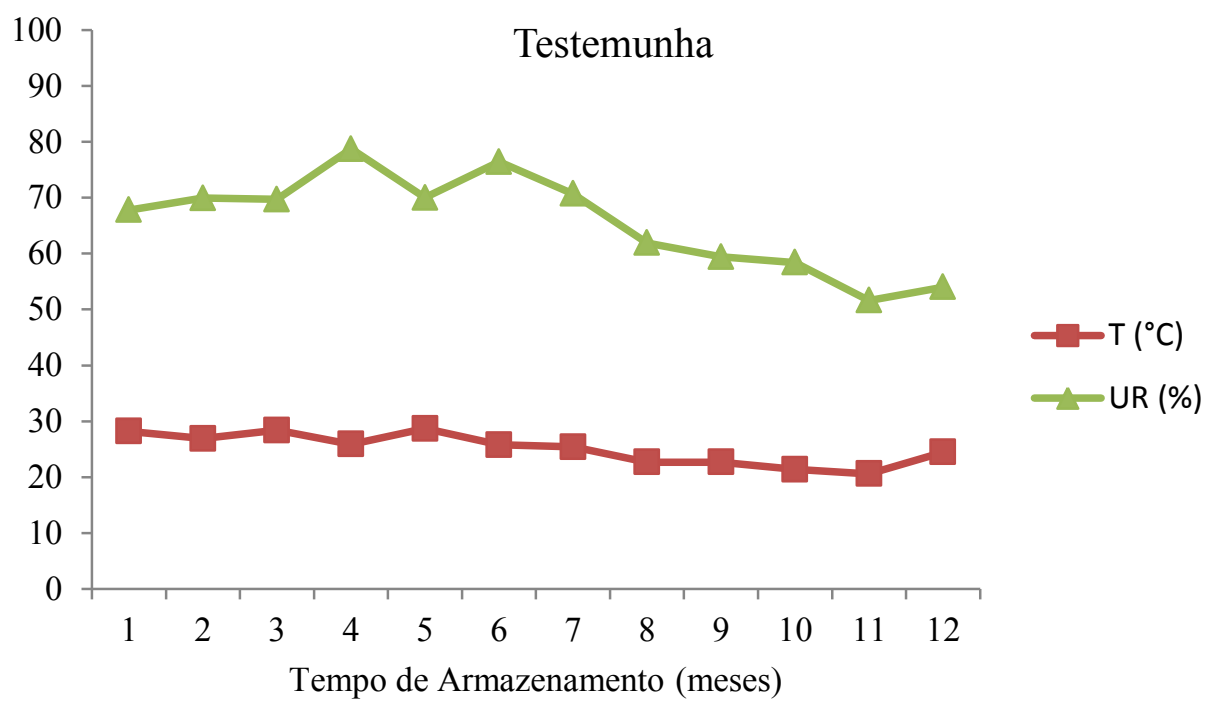

Figura 10. Valores médios mensais da temperatura $\left({ }^{\circ} \mathrm{C}\right)$ e umidade relativa do ar $(\%)$ no ambiente testemunha durante o armazenamento dos grãos de crambe. 
Nos primeiros 6 meses (0-6) as médias dos valores de temperatura e umidade relativa do ar observadas no ambiente Testemunha se mantiveram relativamente constantes $\left(27,3^{\circ} \mathrm{C}\right)(72 \%)$. Nos últimos 6 meses (6-12), foram observados valores de temperatura e umidade relativa do ar mais baixos $(22,9$ C) $(61,8 \%)$, por influência direta de fatores climáticos da região.

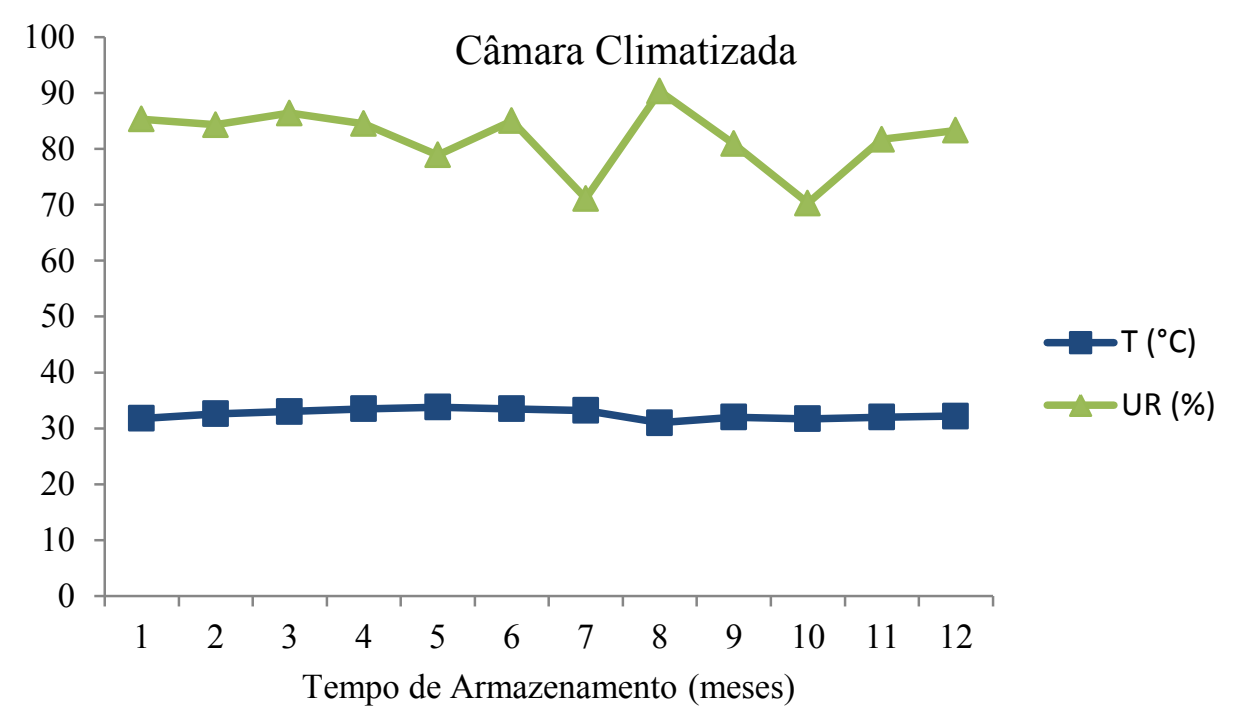

Figura 11. Valores médios da temperatura $\left({ }^{\circ} \mathrm{C}\right)$ e umidade relativa do ar $(\%)$ mensal na câmara climatizada durante o armazenamento dos grãos de crambe.

No ambiente Câmara climatizada, com controle das condições ambientes, a umidade relativa e a temperatura foram mantidas constantes (Câmara Climatizada $\mathrm{T} 32,5^{\circ} \mathrm{C} / \mathrm{UR} 82 \%$ ), ao longo de todo o período de armazenamento. 


\subsection{Avaliação qualitativa dos grãos de crambe}

$\mathrm{Na}$ Tabela 1, são apresentados os valores médios do teor de água (TA - \% b.u), condutividade elétrica ( $\mathrm{CE}-\mu \mathrm{S} \mathrm{cm}^{-1} \mathrm{~g}^{-1}$ ), acidez graxa ( $\mathrm{AG}-\mathrm{mL} \mathrm{KOH} 0,1 \mathrm{~N}$ $100 \mathrm{~g}^{-1} \mathrm{MS}$ ), teor de óleo (TO - \%) e porcentagem de grãos escurecidos (EG - \%) nos grãos de crambe armazenados em dois tipos de embalagens e três ambientes, ao longo do tempo. A análise de variância indicou interação significativa entre os fatores embalagem, ambiente e tempo de armazenamento $(\mathrm{p} \leq 0,01)$. 
Tabela 01. Síntese da análise de variância e do teste de médias do teor de água (TA - \%

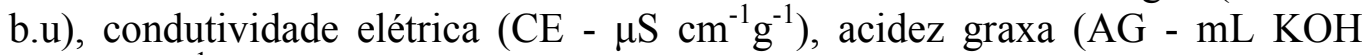
$0,1 \mathrm{~N} 100 \mathrm{~g}^{-1} \mathrm{MS}$ ), teor de óleo (TO - \%) e porcentagem de grãos escurecidos (EG - \%) nos grãos de crambe armazenados em dois tipos de embalagens e três ambientes, ao longo do tempo.

\begin{tabular}{|c|c|c|c|c|c|}
\hline Embalagem & TA & $\mathrm{CE}$ & $\mathrm{AG}$ & TO & EG \\
\hline Bolsa & $7,87 \mathrm{~A}$ & $420,2 \mathrm{~A}$ & $8,90 \mathrm{~A}$ & $33,6 \mathrm{~A}$ & $13,34 \mathrm{~A}$ \\
\hline Sacaria & $8,10 \mathrm{~B}$ & $451,6 \mathrm{~B}$ & $14,73 \mathrm{~A}$ & $33,6 \mathrm{~A}$ & $17,78 \mathrm{~A}$ \\
\hline \multicolumn{6}{|l|}{ Ambiente } \\
\hline Testemunha & $7,57 \mathrm{~A}$ & $417,7 \mathrm{~A}$ & $8,34 \mathrm{~A}$ & $33,8 \mathrm{~A}$ & $11,1 \mathrm{~A}$ \\
\hline Estufa & $7,63 \mathrm{~A}$ & $412,6 \mathrm{~A}$ & $8,48 \mathrm{~A}$ & $33,8 \mathrm{~A}$ & $12,0 \mathrm{~A}$ \\
\hline Câmara & $8,75 \mathrm{~B}$ & $477,4 \mathrm{~A}$ & $18,63 \mathrm{~B}$ & $33,2 \mathrm{~A}$ & $23,6 \mathrm{~B}$ \\
\hline \multicolumn{6}{|l|}{ Tempo } \\
\hline 0 & $7,43 \mathrm{~A}$ & $105,5 \mathrm{~A}$ & $9,11 \mathrm{~A}$ & $29,7 \mathrm{~A}$ & $6,67 \mathrm{~A}$ \\
\hline 6 & $8,07 \mathrm{~B}$ & 498,6 B & $9,89 \mathrm{~B}$ & $34,5 \mathrm{~B}$ & $15,3 \mathrm{~B}$ \\
\hline 12 & $8,45 \mathrm{~B}$ & $703,6 \mathrm{C}$ & $16,46 \mathrm{C}$ & $36,7 \mathrm{C}$ & $24,7 \mathrm{C}$ \\
\hline \multicolumn{6}{|l|}{ Teste de F } \\
\hline $\mathrm{E}$ & $9,34^{*}$ & $47,93 * *$ & $2492,60 * *$ & 0,0n.s. & 3,29n.s. \\
\hline A & $108,19 * *$ & $84,12 * *$ & $3402,15^{* *}$ & 1,57n.s. & $10,71 *$ \\
\hline $\mathrm{T}$ & $64,57 * *$ & $5983,53 * *$ & $1592,39 * *$ & $181,50 * *$ & $18,00 * *$ \\
\hline ExA & $38,09 * *$ & $41,4 * *$ & $2642,52 * *$ & $4,20^{*}$ & 1,18n.s. \\
\hline ExT & $10,14^{*}$ & $17,05^{* *}$ & $1732,20 * *$ & $0,11 \mathrm{n} . \mathrm{s}$. & $12,05^{*}$ \\
\hline $\mathrm{AxT}$ & $44,44 * *$ & $22,59 * *$ & $2336,24 * *$ & 1,63 n.s. & $3,89 *$ \\
\hline ExAxT & $13,31 * *$ & $12,02 * *$ & $1785,97 * *$ & 1,98 n.s. & 1,36 n.s. \\
\hline $\mathrm{CV}(\%)$ & 3,41 & 3,82 & 3,63 & 3,35 & 57,87 \\
\hline
\end{tabular}

$(\mathrm{A}, \mathrm{B}, \mathrm{C})$ Em cada coluna, letras maiúsculas comparam médias de cada fator $(\mathrm{p} \leq 0,05)$.

(n.s.) não significativo $(\mathrm{p} \leq 0,05) ;(*)$ significativo $(\mathrm{p} \leq 0,05) ;(* *)$ significativo $(\mathrm{p} \leq 0,01)$.

\subsubsection{Teor de água no grão}

$\mathrm{Na}$ Tabela 2, são apresentados os valores médios do teor de água dos grãos, acondicionados em diferentes embalagens e condições de ambiente. 
Tabela 2. Valores médios do teor de água (\% b.u.) nos grãos de crambe armazenados em dois tipos de embalagens e três ambientes.

\begin{tabular}{cccc}
\hline \multirow{2}{*}{ Embalagem } & \multicolumn{3}{c}{ Ambientes } \\
\cline { 2 - 4 } & Testemunha & Estufa & Câmara \\
\hline Bolsa & $7,80 \mathrm{Ba}$ & $7,59 \mathrm{Aa}$ & $8,21 \mathrm{Ab}$ \\
Sacaria & $7,32 \mathrm{Aa}$ & $7,66 \mathrm{Ab}$ & $9,29 \mathrm{Bc}$ \\
\hline
\end{tabular}

Médias seguidas por letras distintas, maiúsculas na coluna e minúsculas nas linhas, diferem pelo "teste t" a $5 \%$ de probabilidade.

Os valores médios do teor de água dos grãos, acondicionados em diferentes embalagens variou entre 7,43 a $8,80 \%$ ao longo de 12 meses de armazenamento (Tabela 3).

Tabela 3. Valores médios do teor de água (\% b.u.) nos grãos de crambe armazenados em dois tipos de embalagens ao longo do tempo.

\begin{tabular}{cccc}
\hline \multirow{2}{*}{ Embalagem } & \multicolumn{3}{c}{ Tempo } \\
\cline { 2 - 4 } & 0 & 6 & 12 \\
\hline Bolsa & $7,43 \mathrm{Aa}$ & $8,08 \mathrm{Ab}$ & $8,10 \mathrm{Ab}$ \\
Sacaria & $7,43 \mathrm{Aa}$ & $8,06 \mathrm{Ab}$ & $8,80 \mathrm{Bc}$ \\
\hline
\end{tabular}

Médias seguidas por letras distintas, maiúsculas na coluna e minúsculas nas linhas, diferem pelo "teste t" a $5 \%$ de probabilidade.

Quando a temperatura e a umidade relativa foram mantidas constantes e em níveis elevados, a embalagem bolsa (hermética) foi capaz de resistir às influências do aumento, até o sexto mês de armazenamento, registrando um aumento significativo do teor de água do crambe após 12 meses. A embalagem sacaria permitiu um reumedecimento significativo nos grãos armazenados a partir do sexto mês, mostrando níveis inseguros para a sua conservação ao final dos 12 meses.

A Tabela 4 apresenta os valores médios do teor de água dos grãos, acondicionados em diferentes ambientes nos tempos 0, 6 e 12 meses de armazenamento. Observa-se que aos 12 meses de armazenamento, no ambiente com as maiores médias de umidade relativa do ar, obteve-se o maior teor de água nos grãos armazenados. 
Tabela 4. Valores médios do teor de água (\% b.u.) nos grãos de crambe armazenados em três ambientes ao longo tempo

\begin{tabular}{cccc}
\hline \multirow{2}{*}{ Ambiente } & \multicolumn{3}{c}{ Tempo } \\
\cline { 2 - 4 } & 0 & 6 & 12 \\
\hline Testemunha & $7,43 \mathrm{Aa}$ & $7,64 \mathrm{Aa}$ & $7,62 \mathrm{Aa}$ \\
Estufa & $7,43 \mathrm{Aa}$ & $7,86 \mathrm{Ab}$ & $7,59 \mathrm{Ab}$ \\
Câmara & $7,43 \mathrm{Aa}$ & $8,69 \mathrm{Bb}$ & $10,13 \mathrm{Bc}$ \\
\hline
\end{tabular}

Médias seguidas por letras distintas, maiúsculas na coluna e minúsculas nas linhas, diferem pelo "teste t" a $5 \%$ de probabilidade.

No entanto, os grãos que foram acondicionados na embalagem tipo bolsa (hermética), embora tenham permitido oscilações no teor de água dos grãos de crambe, com variação de 7,43 a 8,03\%, armazenados em condições testadas, que melhor simularam condições naturais (Testemunha $\mathrm{T} 25,1^{\circ} \mathrm{C} / \mathrm{UR}$ 65,4 \%) e (Estufa Agrícola $\mathrm{T}$ $25,9^{\circ} \mathrm{C} / \mathrm{UR} 72,8 \%$ ), ao final do período de armazenamento, observou-se que as médias se mantiveram estáveis e a embalagem bolsa (hermética) mostrou-se mais resistente às influências do ambiente externo. Resultados semelhantes foram confirmados por Costa et al. (2012), que armazenaram grãos de crambe em recipientes de vidro coberto com tecido permeável nas condições ambientes $\left(26 \pm 3{ }^{\circ} \mathrm{C} ; 55 \pm 12 \% \mathrm{UR}\right)$, que permitiu variações no teor de umidade $(5,77-10,55 \%$ b.u. $)$.

As mudanças nas condições do ar causaram constantes alterações nesta variável e ao final do período de 12 meses de armazenamento, não houve uma diminuição significativa do teor de umidade, devido à temperatura e umidade relativa do ar ser mais baixa nesta época do ano (Julho), o que fez com que o fruto alcançasse o equilíbrio com as condições ambientais em que foram armazenados. Alencar et. al (2009), avaliando qualidade dos grãos de soja armazenados em diferentes condições, observou que os grãos acondicionados em recipiente hermético de plástico, em geral, apresentaram teores de água que permaneceram praticamente constantes, com desvio padrão máximo de 0,4 ao longo do armazenamento.

Resultados semelhantes foram obtidos por González -Torralba et al. (2013), estudando a influencia da temperatura e umidade relativa do ar nas propriedades de grãos de trigo armazenados na região Mediterrânea da Europa, em recipiente de vidro, hermeticamente fechado, observaram que após um período de 240 dias, as amostras armazenadas nas condições $\left(30^{\circ} \mathrm{C} / \mathrm{UR} 75 \%\right)$, apresentaram menor 
variação do teor água em relação ao valor de teor de água obtido no inicio do armazenamento $(14.2 \%$ - 14,6\%). Resultados semelhantes formam obtidos por Matos et al. (2008) os quais, verificaram também pequena variação do teor de água nas sementes de pau-pereira, acondicionadas em embalagens herméticas, durante seis meses de armazenamento.

$\mathrm{Na}$ Tabela 5, são apresentados os valores médios do teor de água dos grãos, ao longo dos períodos de armazenamento, acondicionados em diferentes embalagens e condições de ambiente.

Tabela 5. Valores médios do teor de água (\% b.u.) nos grãos de crambe armazenados em dois tipos de embalagens e três ambientes, ao longo do tempo.

Tempo (meses)

\begin{tabular}{ccccc}
\hline Embalagem & Ambiente & 0 & 6 & 12 \\
\hline \multirow{2}{*}{ Bolsa } & Testemunha & $7,43 \mathrm{aA} a$ & $7,96 \mathrm{bA} b$ & $8,03 \mathrm{bB} b$ \\
& Estufa & $7,43 \mathrm{aA} a$ & $8,00 \mathrm{aA} b$ & $7,34 \mathrm{aA} a$ \\
& Câmara & $7,43 \mathrm{aA} a$ & $8,27 \mathrm{aA} b$ & $8,94 \mathrm{aC} c$ \\
\hline \multirow{2}{*}{ Sacaria } & Testemunha & $7,43 \mathrm{aA} a$ & $7,33 \mathrm{aA} a$ & $7,22 \mathrm{aA} a$ \\
& Estufa & $7,43 \mathrm{aA} a$ & $7,73 \mathrm{aA} a$ & $7,85 \mathrm{bB} a$ \\
& Câmara & $7,43 \mathrm{aA} a$ & $9,12 \mathrm{bB} b$ & $11,35 \mathrm{bC} c$ \\
\hline
\end{tabular}

(a,b,c) Em cada linha, letras minúsculas comparam médias das embalagens $(\mathrm{p} \leq 0,05)$.

$(\mathrm{A}, \mathrm{B}, \mathrm{C})$ Em cada coluna, letras maiúsculas comparam médias dos ambientes $(\mathrm{p} \leq 0,05)$.

$(a, b, c)$ Em cada linha, letras minúsculas comparam médias dos tempos $(\mathrm{p} \leq 0,05)$.

(n.s.) não significativo $(\mathrm{p} \leq 0,05) ;(*)$ significativo $(\mathrm{p} \leq 0,05) ;(* *)$ significativo $(\mathrm{p} \leq 0,01)$.

Durante o armazenamento, houve variações nos teores de água dos grãos, em relação ao teor inicial $(7,43 \%)$. Nas duas embalagens estudadas, verificou-se aumento nos resultados, entre 6 e 12 meses de armazenamento, sendo que a avaliação realizada ao final de 12 meses de armazenamento nos grãos que foram acondicionados na embalagem sacaria (convencional), ficou mais suscetível às variações, atingindo teor de água mais baixo, quando armazenado em condições de temperatura mais alta e umidade relativa mais baixa (Testemunha $\mathrm{T} 25,1^{\circ} \mathrm{C} / \mathrm{UR} 65,4 \%$ ), ou mais alto quando armazenado na (Estufa Agrícola $\mathrm{T} 25,9^{\circ} \mathrm{C} / \mathrm{UR} 72,8 \%$ ), com temperaturas mais baixa associada a umidade relativa maior. Além disso, Demostrou reumidecimento no ambiente com as 
maiores médias de umidade relativa do ar (Câmara T 32, $5^{\circ} \mathrm{C} / \mathrm{UR} 82 \%$ ), que evidencia resultados que eram esperados, visto que a embalagem testada proporcionou maior exposição do grão, tendo o mesmo, entrado em equilíbrio higroscópico com o ambiente.

Os resultados corroboram aqueles observados por Bertinetti et al. (2011b) que, estudando os efeitos da hermeticidade no armazenamento de soja, obteve maiores variações no grau de umidade dos grãos armazenados pelo sistema convencional em sacos de rafia, no ambiente $\left(25^{\circ} \mathrm{C} / 70 \% \mathrm{UR}\right)$, durante 12 meses. Masetto et al. (2013), verificaram que esse parâmetro apresentou variação de 6,5 a 10,2\%, independentemente das embalagens e das condições ambientes testadas, no entanto, mostraram aumento do teor de água das sementes no ambiente de câmara fria $\left(15 \pm 2{ }^{\circ} \mathrm{C}\right.$ e $45 \%$ de UR), quando comparado com o teor das sementes acondicionadas em laboratório $\left(25 \pm 2{ }^{\circ} \mathrm{C}\right.$ e $60 \%$ de UR). Quando os grãos são armazenados em embalagens permeáveis, seu teor de água altera conforme as variações da umidade do ar, por serem higroscópicas (BAUDET, 2003).

Segundo Queiroga et al. (2009), quanto mais baixo for o teor de água das sementes durante o armazenamento, maior será sua longevidade. Marcos Filho (2005) destacou que as sementes devem ser mantidas com grau de umidade de 10 a $12 \%$ para o armazenamento durante seis a oito meses, sendo os valores mais baixos indicados para espécies como o crambe, em que predominam reservas de lipídeos.

\subsubsection{Condutividade elétrica}

$\mathrm{Na}$ Tabela 6, estão apresentados os valores médios de condutividade elétrica de grãos acondicionados em diferentes embalagens e condições ambientes.

Tabela 6. Valores médios de condutividade elétrica $\left(\mathrm{CE}-\mu \mathrm{S} \mathrm{cm} \mathrm{cm}^{-1}\right)$ nos grãos de crambe armazenados em dois tipos de embalagens e três ambientes.

\begin{tabular}{cccc}
\hline \multirow{2}{*}{ Embalagem } & \multicolumn{3}{c}{ Ambientes } \\
\cline { 2 - 4 } & Testemunha & Estufa & Câmara \\
\hline Bolsa & $414,0 \mathrm{Aa}$ & $413,9 \mathrm{Aa}$ & $432,7 \mathrm{Aa}$ \\
Sacaria & $421,4 \mathrm{Aa}$ & $411,2 \mathrm{Aa}$ & $522,2 \mathrm{Bb}$ \\
\hline
\end{tabular}

Médias seguidas por letras distintas, maiúsculas na coluna e minúsculas nas linhas, diferem pelo "teste t" a $5 \%$ de probabilidade. 
A embalagem sacaria (convencional), armazenada na (Câmara Climatizada T $\left.32,5^{\circ} \mathrm{C} / \mathrm{UR} 82 \%\right)$, apresentou valores de lixiviados maiores $\left(522,2 \mu \mathrm{S} \mathrm{cm}^{-}\right.$ $\left.{ }^{1} \mathrm{~g}^{-1}\right)$ que os valores encontrados no início $\left(421,4 \mu \mathrm{S} \mathrm{cm} \mathrm{g}^{-1}\right)$ do armazenamento. Resultados semelhantes foram encontrados por Costa et al. (2013), em sementes de Apeiba tibourbou Aubl acondicionadas em sacos de papel Kraft, onde se verificou um aumento na quantidade de eletrólitos liberados pelas sementes durante o armazenamento, na câmara climatizada ( $\left.18^{\circ} \mathrm{C} ; 57 \% \mathrm{UR}\right)$, o que confirma a influência do tempo de armazenamento e condições ambientes na quantidade de solutos lixiviados.

Como mostra na Tabela 7, o maior valor de condutividade elétrica foi observado na embalagem sacaria, aos 12 meses de armazenamento.

Tabela 7. Valores médios de condutividade elétrica $\left(\mathrm{CE}-\mu \mathrm{S} \mathrm{cm}^{-1} \mathrm{~g}^{-1}\right)$ nos grãos de crambe armazenados em dois tipos de embalagens ao longo do tempo.

\begin{tabular}{cccc}
\hline \multirow{2}{*}{ Embalagem } & \multicolumn{3}{c}{ Tempo } \\
\cline { 2 - 4 } & 0 & 6 & 12 \\
\hline Bolsa & $105,5 \mathrm{Aa}$ & $466,2 \mathrm{Ab}$ & $688,9 \mathrm{Ac}$ \\
Sacaria & $105,5 \mathrm{Aa}$ & $531 \mathrm{Bb}$ & $718,3 \mathrm{Bc}$ \\
\hline
\end{tabular}

Médias seguidas por letras distintas, maiúsculas na coluna e minúsculas nas linhas, diferem pelo "teste t" a $5 \%$ de probabilidade.

Os resultados de condutividade elétrica nos grãos de crambe armazenados em três ambientes ao longo do tempo são apresentados na Tabela 8.

Tabela 8. Valores médios de condutividade elétrica $\left(\mathrm{CE}-\mu \mathrm{S} \mathrm{cm}^{-1} \mathrm{~g}^{-1}\right)$ nos grãos de crambe armazenados em três ambientes ao longo do tempo.

\begin{tabular}{cccc}
\hline \multirow{2}{*}{ Ambiente } & \multicolumn{3}{c}{ Tempo } \\
\cline { 2 - 4 } & 0 & 6 & 12 \\
\hline Testemunha & $105,5 \mathrm{Aa}$ & $462,4 \mathrm{Ab}$ & $685,3 \mathrm{Ac}$ \\
Estufa & $105,5 \mathrm{Aa}$ & $464,4 \mathrm{Ab}$ & $667,76 \mathrm{Ac}$ \\
Câmara & $105,5 \mathrm{Aa}$ & $568,9 \mathrm{Bb}$ & $757,83 \mathrm{Bc}$ \\
\hline
\end{tabular}

Médias seguidas por letras distintas, maiúsculas na coluna e minúsculas nas linhas, diferem pelo "teste t" a $5 \%$ de probabilidade.

A quantidade de íons lixiviados encontrados na solução de embebição do crambe, em função da deterioração da membrana celular dos grãos, que ocorreu durante o armazenamento, foi estatisticamente maior aos 6 e 12 meses, nas duas embalagens e para todos ambientes estudados. 
$\mathrm{Na}$ Tabela 9, estão apresentados os valores médios de condutividade elétrica de grãos acondicionados em diferentes embalagens e condições ambientes, durante 12 meses de armazenamento.

Tabela 9. Valores médios de condutividade elétrica $\left(\mathrm{CE}-\mu \mathrm{S} \mathrm{cm} \mathrm{g}^{-1}\right)$ nos grãos de crambe armazenados em dois tipos de embalagens e três ambientes, ao longo do tempo.

\begin{tabular}{ccccc}
\hline & & \multicolumn{3}{c}{ Tempo (meses) } \\
\hline Embalagem & Ambiente & 0 & 6 & 12 \\
\hline \multirow{3}{*}{ Bolsa } & Testemunha & $105,5 \mathrm{aA} a$ & $455,5 \mathrm{aA} b$ & $681 \mathrm{aA} c$ \\
& Estufa & $105,5 \mathrm{aA} a$ & $459,8 \mathrm{aAB} b$ & $676,4 \mathrm{aA} c$ \\
& Câmara & $105,5 \mathrm{aA} a$ & $483,2 \mathrm{aB} b$ & $709,3 \mathrm{aB} c$ \\
\hline \multirow{3}{*}{ Sacaria } & Testemunha & $105,5 \mathrm{aA} a$ & $469,4 \mathrm{aAb}$ & $689,5 \mathrm{aA} c$ \\
& Estufa & $105,5 \mathrm{aA} a$ & $469 \mathrm{aA} b$ & $659,1 \mathrm{aA} c$ \\
& Câmara & $105,5 \mathrm{aA} a$ & $654,6 \mathrm{bB} b$ & $806,4 \mathrm{bC} c$ \\
\hline
\end{tabular}

$(a, b, c)$ Em cada linha, letras minúsculas comparam médias das embalagens $(p \leq 0,05)$.

$(\mathrm{A}, \mathrm{B}, \mathrm{C})$ Em cada coluna, letras maiúsculas comparam médias dos ambientes $(\mathrm{p} \leq 0,05)$.

$(a, b, c)$ Em cada linha, letras minúsculas itálico comparam médias dos tempos $(\mathrm{p} \leq 0,05)$.

(n.s.) não significativo $(\mathrm{p}>0,05) ;(*)$ significativo $(\mathrm{p} \leq 0,05) ;(* *)$ significativo $(\mathrm{p} \leq 0,01)$.

Ao final do período de armazenamento, a bolsa (hermética) apresentou valores médios menores de íons lixiviados que se diferiram dos apresentados pela embalagem sacaria (convencional) armazenados nos ambientes (Estufa Agrícola $\mathrm{T}$ $25,9^{\circ} \mathrm{C} / \mathrm{UR} 72,8 \%$ ) e (Testemunha T $25,1^{\circ} \mathrm{C} / \mathrm{UR} 65,4 \%$ ), se mostrando mais eficiente na manutenção da qualidade dos grãos. Resultado semelhante foi encontrado por Santos (2008), que avaliando a qualidade de grãos de milho armazenados em bolsas herméticas, em ambientes com médias de temperatura $35^{\circ} \mathrm{C}$ observou aumento dos valores de condutividade elétrica em função do tempo.

\subsubsection{Acidez graxa}

Acidez graxa é comumente usada como um índice de deterioração da qualidade durante o armazenamento, porque a dissolução de lipídios progride de forma mais rápida do que a proteína e o amido (GENKAWA et al., 2008). Na tabela 10, estão apresentadas as médias dos valores de ácidos graxos livres dos grãos de crambe condicionados em diferentes embalagens e condições ambientes. 
Tabela 10. Valores médios de acidez graxa (AG - mL KOH $0,1 \mathrm{~N} 100 \mathrm{~g}^{-1} \mathrm{MS}$ ) nos grãos de crambe armazenados em dois tipos de embalagens e três ambientes.

\begin{tabular}{cccc}
\hline \multirow{2}{*}{ Embalagem } & \multicolumn{3}{c}{ Ambientes } \\
\cline { 2 - 4 } & Testemunha & Estufa & Câmara \\
\hline Bolsa & $8,44 \mathrm{Aa}$ & $8,55 \mathrm{Aa}$ & $9,71 \mathrm{Ab}$ \\
Sacaria & $8,25 \mathrm{Aa}$ & $8,42 \mathrm{Aa}$ & $27,6 \mathrm{Bb}$ \\
\hline
\end{tabular}

Médias seguidas por letras distintas, maiúsculas na coluna e minúsculas nas linhas, diferem pelo "teste t" a $5 \%$ de probabilidade.

A embalagem bolsa (hermética) manteve controlados os níveis de ácidos graxos em todos ambientes, preservando a qualidade dos grãos. Park et al. (2012), analisando as mudanças nas características físico-químicas de arroz durante $\mathrm{o}$ armazenamento em diferentes temperaturas na Korea, observam valores mais elevados de ácidos graxos livres obtidos no arroz armazenado a $40^{\circ} \mathrm{C}(14,37 \mathrm{~mL} \mathrm{KOH} / 100 \mathrm{MS})$ após 4 meses de armazenamento.

Houve diferença entre os tratamentos no índice de ácidos graxos nos grãos de crambe armazenados aos 6 e 12 meses (Tabela 11).

Tabela 11. Valores médios de acidez graxa (AG - mL KOH $0,1 \mathrm{~N} 100 \mathrm{~g}^{-1} \mathrm{MS}$ ) nos grãos de crambe armazenados em dois tipos de embalagens ao longo do tempo.

\begin{tabular}{cccc}
\hline \multirow{2}{*}{ Embalagem } & \multicolumn{3}{c}{ Tempo } \\
\cline { 2 - 4 } & 0 & 6 & 12 \\
\hline Bolsa & $9,11 \mathrm{Aa}$ & $8,88 \mathrm{Aa}$ & $8,71 \mathrm{Aa}$ \\
Sacaria & $9,11 \mathrm{Aa}$ & $10,9 \mathrm{Bb}$ & $24,2 \mathrm{Bc}$ \\
\hline
\end{tabular}

Médias seguidas por letras distintas, maiúsculas na coluna e minúsculas nas linhas, diferem pelo "teste t" a $5 \%$ de probabilidade.

Aos 6 meses, a embalagem sacaria (convencional) já se mostrou ineficiente com elevados teores de ácidos graxos (10,9) e aos 12 meses observou-se o pior resultado na sacaria armazenada no ambiente câmara(24,2). No entanto, a embalagem bolsa (hermética) apresentou médias de ácidos graxos nos grãos que se mantiveram estatisticamente iguais ao final dos 12 meses de armazenamento.

Na Tabela 12, são apresentados os valores médios de acidez graxa nos grãos de crambe armazenados em três ambientes ao longo do tempo. 
Tabela 12. Valores médios de acidez graxa (AG - mL KOH $0,1 \mathrm{~N} 100 \mathrm{~g}^{-1} \mathrm{MS}$ ) nos grãos de crambe armazenados em três ambientes ao longo do tempo.

\begin{tabular}{cccc}
\hline \multirow{2}{*}{ Ambiente } & \multicolumn{3}{c}{ Tempo } \\
\cline { 2 - 4 } & 0 & 6 & 12 \\
\hline Testemunha & $9,11 \mathrm{Aa}$ & $8,63 \mathrm{Ab}$ & $7,28 \mathrm{Aa}$ \\
Estufa & $9,11 \mathrm{Aa}$ & $8,72 \mathrm{Ab}$ & $7,62 \mathrm{Aa}$ \\
Câmara & $9,11 \mathrm{Aa}$ & $12,3 \mathrm{Bb}$ & $34,5 \mathrm{Bc}$ \\
\hline
\end{tabular}

Médias seguidas por letras distintas, maiúsculas na coluna e minúsculas nas linhas, diferem pelo "teste t" a $5 \%$ de probabilidade.

Na tabela 13, estão apresentadas as médias dos valores de ácidos graxos livres dos grãos de crambe condicionados em diferentes embalagens e condições ambientes ao longo de 12 meses.

Tabela 13. Valores médios de acidez graxa (AG - mL KOH $0,1 \mathrm{~N} 100 \mathrm{~g}^{-1} \mathrm{MS}$ ) nos grãos de crambe armazenados em dois tipos de embalagens e três ambientes, ao longo do tempo.

\begin{tabular}{ccccc}
\hline & & \multicolumn{3}{c}{ Tempo (meses) } \\
\hline \multirow{2}{*}{ Embalagem } & Ambiente & 0 & 6 & 12 \\
\hline \multirow{2}{*}{ Bolsa } & Testemunha & $9,1 \mathrm{aA} b$ & $8,73 \mathrm{aA} b$ & $7,5 \mathrm{aA} a$ \\
& Estufa & $9,1 \mathrm{aAb}$ & $8,83 \mathrm{aA} b$ & $7,71 \mathrm{aA} a$ \\
& Câmara & $9,1 \mathrm{aA} a$ & $9,08 \mathrm{aA} a$ & $10,94 \mathrm{aB} b$ \\
\hline \multirow{2}{*}{ Sacaria } & Testemunha & $9,1 \mathrm{aA} b$ & $8,54 \mathrm{aA} b$ & $7,05 \mathrm{aA} a$ \\
& Estufa & $9,1 \mathrm{aA} b$ & $8,61 \mathrm{aA} b$ & $7,53 \mathrm{aA} a$ \\
& Câmara & $9,1 \mathrm{aA} a$ & $15,53 \mathrm{bB} b$ & $58,01 \mathrm{bB} c$ \\
\hline
\end{tabular}

$(a, b, c)$ Em cada linha, letras minúsculas comparam médias das embalagens $(p \leq 0,05)$.

$(\mathrm{A}, \mathrm{B}, \mathrm{C})$ Em cada coluna, letras maiúsculas comparam médias dos ambientes $(\mathrm{p} \leq 0,05)$.

$(a, b, c)$ Em cada linha, letras minúsculas comparam médias dos tempos $(\mathrm{p} \leq 0,05)$.

(n.s.) não significativo $(\mathrm{p} \leq 0,05) ;(*)$ significativo $(\mathrm{p} \leq 0,05) ;(* *)$ significativo $(\mathrm{p} \leq 0,01)$.

O índice de ácidos graxos indica a deterioração causada pelo ambiente de armazenamento ao longo do tempo. De modo geral, o ambiente com temperatura e umidade relativa do ar (Câmara Climatizada T 32, $5^{\circ} \mathrm{C} / \mathrm{UR} 82$ \%) mais alta, resultou em maiores teores de acidez graxa, com valores que variaram de 9,1 a 58,01 mL de $\mathrm{KOH} 100 \mathrm{~g}^{-1} \mathrm{MS}$. Os resultados aproximam-se daqueles obtidos por Sravanthi et al. (2013), que, avaliando o efeito das condições de armazenamento em lentilhas vermelhas, 
observaram aumento de seis vezes no valor de ácidos graxos livres quando armazenadas a $40{ }^{\circ} \mathrm{C}$, com teor de água $17,5 \%$ b.u.

\subsection{4 rendimento de óleo}

Na tabela 14, estão apresentadas as médias dos teores de óleo dos grãos de crambe condicionados em diferentes embalagens e condições ambientes. Pela análise dos dados, detectou influência significativa das embalagens estudadas no ambiente Estufa tendo - se registrado teores de 32,6 e 33,8\% na Sacaria (convencional) e na Bolsa (hermética) respetivamente.

Tabela 14. Valores médios do teor de óleo (\%) nos grãos de crambe armazenados em dois tipos de embalagens e três ambientes.

\begin{tabular}{cccc}
\hline \multirow{2}{*}{ Embalagem } & \multicolumn{3}{c}{ Ambientes } \\
\cline { 2 - 4 } & Testemunha & Estufa & Câmara \\
\hline Bolsa & $33,3 \mathrm{Aa}$ & $33,7 \mathrm{Aa}$ & $33,8 \mathrm{Ba}$ \\
Sacaria & $34,2 \mathrm{Ab}$ & $34 \mathrm{Ab}$ & $32,6 \mathrm{Aa}$ \\
\hline Médias & seguidas por letras distintas, maúsculs na coluna e minúsculas nas linhas, diferem pelo "teste t" a
\end{tabular}

Médias seguidas por letras distintas, maiúsculas na coluna e minúsculas nas linhas, diferem pelo "teste t" a $5 \%$ de probabilidade.

De modo geral, houve acréscimo significativo no teor de óleo nos grãos nos primeiros 6 meses de armazenamento, nas duas embalagens estudadas, fato que pode ser explicado pela ocorrência da lipoperoxidação, que em função da ação de enzimas específicas, atuam na diminuição do conteúdo de açúcar e no aumento de lipídios. Em valores absolutos, os níveis de óleo encontrados neste trabalho aproximam - se dos publicados pela Fundação MS (2011), que encontraram de 36 a 38\% de óleo no grão de crambe, na extração por solvente.

Ao final do armazenamento, a embalagem bolsa (hermética) se mostrou mais eficiente na manutenção do teor de óleo dos grãos, com valores médios que pouco variaram independente do ambiente de armazenamento. No entanto, os teores de óleo encontrados na embalagem sacaria (convencional), foram o segundo maior nos tratamentos armazenados no ambiente mais crítico, (Câmara Climatizada T 32, $5^{\circ} \mathrm{C} / \mathrm{UR}$ $82 \%$ ). Estes resultados corroboram os observados por Zhou et al. (2002) que mostraram a influência da temperatura e do período de armazenamento no teor de lipídios em grãos de arroz, relatando que em grãos armazenados a $35{ }^{\circ} \mathrm{C}$ ocorre decréscimo significativo do teor de lipídios. 
A menor média do teor de óleo do grão $(33,30 \%)$ foi observada na embalagem Sacaria (convencional) no ambiente (Testemunha T $25,1^{\circ} \mathrm{C} / \mathrm{UR} 65,4 \%$ ) que se obteve também a menor média de ácidos graxos $(8,25 \mathrm{ml} \mathrm{KOH} / 100 \mathrm{~g})$. A redução no teor de lipídios e o aumento no teor de ácidos graxos livres estão diretamente correlacionados com a velocidade e intensidade do processo deteriorativo dos grãos. A avaliação desses índices constitui-se em eficiente parâmetro para o controle da conservabilidade de grãos durante o armazenamento (MARINI et al., 2005). Lee e Cho (2012) apresentaram significativa redução do teor de lipídeos na soja após um ano de armazenamento em temperatura ambiente. A média de óleo entre as cultivares armazenadas diminuiu de 19,8\% para $17,7 \%$ e isto foi atribuído à lipólise e oxidação do óleo quando expostos a fatores como ar, luz, calor e tempo de armazenamento.

\subsubsection{Escurecimento do grão}

A variação na coloração caracteriza o envelhecimento dos grãos e está associada a outras alterações qualitativas, na composição e propriedades causadas ainda durante o armazenamento (Liu et al., 2013). Observa-se, pelos resultados apresentados na Tabela 15, que a coloração dos grãos de crambe armazenados nas embalagens analisadas se diferiu ao longo dos 12 meses.

Tabela 15. Porcentagem média de grãos de crambe escurecidos armazenados em dois tipos de embalagens ao longo do tempo.

\begin{tabular}{cccc}
\hline \multirow{2}{*}{ Embalagem } & \multicolumn{3}{c}{ Tempo } \\
\cline { 2 - 4 } & 0 & 6 & 12 \\
\hline Bolsa & $6,67 \mathrm{Aa}$ & $11,6 \mathrm{Aa}$ & $14,2 \mathrm{Ab}$ \\
Sacaria & $6,67 \mathrm{Aa}$ & $19,1 \mathrm{Ab}$ & $35,1 \mathrm{Bb}$ \\
\hline Médias seguidas por letras distintas, maiúsculas na coluna e minúsculas nas linhas, diferem pelo "teste t" a \\
5\% de probabilidade.
\end{tabular}

Os grãos de crambe apresentaram acréscimo no escurecimento nas duas embalagens sacaria (convencional) e bolsa (hermética), se intensificando ao longo do tempo. Como era esperado, as maiores porcentagens de grãos escurecidos ocorreram após um período de armazenamento, sendo que, também neste momento, a embalagem bolsa (hermética) (14,2\%) apresentou melhor desempenho em relação à sacaria (convencional) $(35,1 \%)$, se diferindo estatisticamente, registrando uma porcentagem de escurecidos inferior. 
A embalagem bolsa (hermética) não apenas retardou o processo de escurecimento, como também amenizou sua intensidade. Este fato pode ser explicado pelo ambiente anaeróbio criado neste tipo de embalagem, o que proporciona redução da atividade da enzima polifenoloxidase (oxidação enzimática) desencadeada pela atividade microbiológica nos grãos reumedecidos.

Além disso, a embalagem bolsa (hermética) permitiu aumento da porcentagem de grãos escurecidos até os 6 meses e se manteve relativamente constante ao final de 12 meses de armazenamento, apresentando valores menores e diferentes estatisticamente que os obtidos na embalagem sacaria (convencional) nas mesmas condições de temperatura e umidade relativa do ar. Para Pohndorf (2012), os grãos de soja acondicionados em embalagens plásticas, armazenados com umidade de 16\% durante 6 meses apresentaram escurecimento mais intenso a partir do terceiro mês e mantiveram uma tendência linear ao longo dos 6 meses, no ambiente com maior média de temperatura $\left(28^{\circ} \mathrm{C}\right)$. Resultados semelhantes foram observados por Park et al. (2012b), avaliando a brancura de arroz, relatou que a cor do arroz mudou de cor branco cremoso à amarelo após 1 mês de armazenamento e manteve-se relativamente constante.

Na tabela 16, estão apresentados a porcentagem média de grãos escurecidos em cada ambiente nos tempos 0, 6 e 12 meses de armazenamento.

Tabela 16. Porcentagem média de grãos de crambe escurecidos nos grãos de crambe armazenados em três ambientes ao longo do tempo.

\begin{tabular}{cccc}
\hline \multirow{2}{*}{ Ambiente } & \multicolumn{3}{c}{ Tempo } \\
\cline { 2 - 4 } & 0 & 6 & 12 \\
\hline Testemunha & $6,67 \mathrm{Aa}$ & $10,7 \mathrm{Aa}$ & $16 \mathrm{Aa}$ \\
Estufa & $6,67 \mathrm{Aa}$ & $12,7 \mathrm{Ba}$ & $16,7 \mathrm{Aa}$ \\
Câmara & $6,67 \mathrm{Aa}$ & $22,7 \mathrm{Bb}$ & $41,3 \mathrm{Bc}$ \\
\hline
\end{tabular}

Médias seguidas por letras distintas, maiúsculas na coluna e minúsculas nas linhas, diferem pelo "teste t" a $5 \%$ de probabilidade.

As embalagens armazenadas em condições de envelhecimento acelerado (Câmara Climatizada T 32, $5^{\circ} \mathrm{C} / \mathrm{UR} 82$ \%), não manteve a qualidade dos grãos ao longo do tempo, com valor médio de grão escurecido $(41,3 \%)$ seis vezes maior que o valor obtido no início do armazenamento $(6,67 \%)$. Esse resultado confirma o incremento na atividade metabólica dos grãos devido ao reumedecimento ocasionado pelo ambiente e a consequente elevação do índice de lixiviados apresentado pela Tabela 8, na mesma situação de armazenamento, devido ao desenvolvimento de fungos e à elevação do 
percentual de ardidos. O escurecimento do grão, segundo Saio et al. (1980), é um importante indicador de deterioração qualitativa durante o armazenamento.

Resultados semelhantes foram observados por Paraginski R. T et al (2013) que, avaliando as características de milho em função da temperatura de armazenamento, obteve que maior mudança de cor ocorreu nos grãos de milho armazenados a $35^{\circ} \mathrm{C}$, em comparação com os grãos antes do armazenamento. Alencar et al. (2009), analisando qualidade dos grãos de soja armazenados em diferentes condições, verificaram elevação na diferença de cor dos grãos durante o armazenamento, aumento este mais acentuado a medida em que se elevou o teor de água e a temperatura dos grãos.

\subsection{Avaliação qualitativa do óleo bruto extraído de crambe}

$\mathrm{Na}$ Tabela 17, são apresentados os valores médios o teor de água

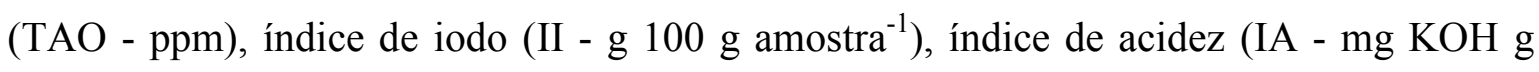
$\left.\operatorname{amostra}^{-1}\right)$, viscosidade cinemática $\left(\mathrm{VC}-\mathrm{mm}^{2} / \mathrm{s}\right)$ e da massa específica $\left(\mathrm{ME}-\mathrm{g} / \mathrm{cm}^{3}\right)$ do óleo bruto extraído de grãos de crambe armazenados em dois tipos de embalagens e três ambientes, ao longo do tempo. A análise de variância indicou interação significativa entre os fatores embalagem, ambiente e tempo de armazenamento $(p \leq 0,01)$. 
Tabela 17. Síntese da análise de variância e do teste de médias para o teor de água (TAO ppm), índice de iodo (II - g $100 \mathrm{~g}^{\text {amostra }^{-1}}$ ), índice de acidez (IA - mg KOH g amostra $^{-1}$ ), viscosidade cinemática $\left(\mathrm{VC}-\mathrm{mm}^{2} / \mathrm{s}\right)$ e da massa específica (ME $\mathrm{g} / \mathrm{cm}^{3}$ ) do óleo bruto extraído de grãos de crambe armazenados em dois tipos de embalagens e três ambientes, ao longo do tempo.

\begin{tabular}{cccccc}
\hline Embalagem & TAO & II & IA & VC & ME \\
\hline Bolsa & $848,4 \mathrm{~A}$ & $91,2 \mathrm{~A}$ & $0,82 \mathrm{~A}$ & $49,6 \mathrm{~B}$ & $0,9064 \mathrm{~A}$ \\
Sacaria & $906,1 \mathrm{~A}$ & $92,6 \mathrm{~B}$ & $2,62 \mathrm{~B}$ & $49,4 \mathrm{~A}$ & $0,9065 \mathrm{~A}$ \\
\hline Ambiente & & & & & \\
\hline Testemunha & $851,0 \mathrm{~A}$ & $92 \mathrm{~A}$ & $1,01 \mathrm{~A}$ & $49,6 \mathrm{~B}$ & $0,9064 \mathrm{~A}$ \\
Estufa & $924,8 \mathrm{~A}$ & $92,2 \mathrm{~A}$ & $3,11 \mathrm{~B}$ & $49,5 \mathrm{~B}$ & $0,9064 \mathrm{~A}$ \\
Câmara & $856,0 \mathrm{~A}$ & $91,4 \mathrm{~A}$ & $1,05 \mathrm{~A}$ & $49,3 \mathrm{~A}$ & $0,9066 \mathrm{~B}$ \\
\hline Tempo & & & & & \\
\hline 0 & $1300 \mathrm{~B}$ & $91,3 \mathrm{~A}$ & $0,41 \mathrm{~A}$ & $49,6 \mathrm{~B}$ & $0,9067 \mathrm{~B}$ \\
6 & $635,5 \mathrm{~A}$ & $92,3 \mathrm{~B}$ & $1,88 \mathrm{~B}$ & $49,4 \mathrm{~A}$ & $0,9061 \mathrm{~A}$ \\
12 & $696,3 \mathrm{~A}$ & $92 \mathrm{~B}$ & $2,87 \mathrm{C}$ & $49,4 \mathrm{~A}$ & $0,9066 \mathrm{~B}$ \\
\hline Teste de F & & & & \\
\hline E & $0,41^{\text {n.s. }}$ & $10,91^{*}$ & $100,42^{* *}$ & $24,24^{* *}$ & $0,52^{\text {n.s. }}$ \\
A & $0,28^{\text {n.s. }}$ & $1,27^{\text {n.s. }}$ & $59,89^{* *}$ & $21,73^{* *}$ & $3,10^{\text {n.s. }}$ \\
T & $22,19^{* *}$ & $2,34^{\text {n.s. }}$ & $62,32^{* *}$ & $10,00^{*}$ & $38,50^{* *}$ \\
ExA & $0,29^{\text {n.s. }}$ & $0,88^{\text {n.s. }}$ & $62,59^{* *}$ & $16,54^{* *}$ & $0,56^{\text {n.s. }}$ \\
ExT & $0,72^{\text {n.s. }}$ & $5,97^{*}$ & $53,24^{* *}$ & $10,77^{*}$ & $3,61^{\text {n.s. }}$ \\
AxT & $0,54^{\text {n.s }}$ & $0,56^{\text {n.s. }}$ & $40,92^{* *}$ & $9,17^{* *}$ & $3,30^{*}$ \\
ExAxT & $0,21^{\text {n.s. }}$ & $0,28^{\text {n.s. }}$ & $32,30^{* *}$ & $13,51^{* *}$ & $1,06^{\text {n.s. }}$ \\
\hline CV(\%) & 37,72 & 1,68 & 38,27 & 0,24 & 0,02 \\
\hline A & & &
\end{tabular}

(A,B,C) Em cada coluna, letras maiúsculas comparam médias de cada fator $(\mathrm{p} \leq 0,05)$.

(n.s.) não significativo $(\mathrm{p} \leq 0,05) ;(*)$ significativo $(\mathrm{p} \leq 0,05) ;(* *)$ significativo $(\mathrm{p} \leq 0,01)$.

\subsubsection{Teor de água}

Na Tabela 18, são apresentados os valores médios do teor de água no óleo bruto extraídos dos grãos de crambe, acondicionados em diferentes embalagens e condições ambientes, ao longo de 12 meses de armazenamento. O teor de água médio do óleo, entre os tratamentos foi de 714,7 ppm. Esse valor ficou abaixo do limite máximo estipulado pela ANP, que é de $0,5 \% \mathrm{v} / \mathrm{v}$. 
Tabela 18. Valores médios do Teor de água (ppm) no óleo bruto extraído de grãos de crambe armazenados em dois tipos de embalagens e três ambientes, ao longo do tempo crambe em cada método de armazenamento.

Tempo (meses)

\begin{tabular}{ccccc}
\hline Embalagem & Ambiente & 0 & 6 & 12 \\
\hline \multirow{2}{*}{ Bolsa } & Testemunha & $1300 \mathrm{aA} b$ & $526,07 \mathrm{aA} a$ & $604,17 \mathrm{aA} a$ \\
& Estufa & $1300 \mathrm{aA} b$ & $739,57 \mathrm{aA} a$ & $580,83 \mathrm{aA} a$ \\
& Câmara & $1300 \mathrm{aA} b$ & $694,73 \mathrm{aA} a$ & $590,23 \mathrm{aA} a$ \\
\hline \multirow{2}{*}{ Sacaria } & Testemunha & $1300 \mathrm{aA} b$ & $507,97 \mathrm{aA} a$ & $867,67 \mathrm{aA} a b$ \\
& Estufa & $1300 \mathrm{aA} b$ & $671,37 \mathrm{aA} a$ & $544,27 \mathrm{aA} a$ \\
& Câmara & $1300 \mathrm{aA} b$ & $673,07 \mathrm{aA} a$ & $990,90 \mathrm{aA} a b$ \\
\hline CV $(\%): 37,72$ & & F Tempo: $22,19^{* *}$ & & F AxT: $0,54^{\text {n.s }}$. \\
F Embalagem: $0,41^{\text {n.s. }}$ & & F ExA: $0,29^{\text {n.s. }}$ & & F ExAxT: $0,21^{\text {n.s. }}$ \\
F Ambiente: $0,28^{\text {n.s. }}$ & & F ExT: $0,72^{\text {n.s. }}$ & & QMR: 36 \\
\hline
\end{tabular}

$(a, b, c)$ Em cada linha, letras minúsculas comparam médias das embalagens $(p \leq 0,05)$.

$(\mathrm{A}, \mathrm{B}, \mathrm{C})$ Em cada coluna, letras maiúsculas comparam médias dos ambientes $(\mathrm{p} \leq 0,05)$.

$(a, b, c)$ Em cada linha, letras minúsculas comparam médias dos tempos $(\mathrm{p} \leq 0,05)$.

(n.s.) não significativo $(\mathrm{p} \leq 0,05) ;(*)$ significativo $(\mathrm{p} \leq 0,05) ;(* *)$ significativo $(\mathrm{p} \leq 0,01)$.

Até os 6 primeiros meses de armazenamento, ocorreu diminuição nos teores de água no oléo bruto, extraído dos grãos armazenados nas embalagens sacaria semi - permeável e bolsa hermética, que se deve pelo comportamento da água na massa de grão, que se redistribui depois de ser armazenada no novo ambiente, demonstrando comportamento de readequação à nova condição a qual o grão está submetido.

Aos 12 meses de armazenamento, o teor de água no óleo bruto, extraído dos grãos que formam armazenados na bolsa hermética diminuiu, enquanto na embalagem sacaria, o teor de água no óleo aumentou no ambiente (Câmara $\mathrm{T} 32,5^{\circ} \mathrm{C} / \mathrm{UR}$ $82 \%)$, com o maior valor médio observado, $(990,00 \mathrm{ppm})$. No mesmo tratamento foi observada a maior média do teor de água no grão, com (11,35\% b. u.), que evidencia que os resultados obtidos nas análises estão relacionados.

Nos últimos 2 meses de armazenamento foi registrada a menor média de umidade relativa do ar (59,5\%) no ambiente Estufa, onde foi observado o menor teor de água no óleo extraído dos grãos armazenados na sacaria (544,27 ppm). Quando os 
grãos são armazenados em embalagens permeáveis, seu teor de água altera conforme as variações da umidade do ar, por serem higroscópicas (BAUDET, 2003).

\subsection{2 Índice de Iodo}

Na Tabela 19, são apresentados os valores médios de índice de iodo do óleo bruto de crambe, acondicionados em diferentes embalagens e condições ambientes.

Tabela 19. Valores médios do Índice de Iodo $\left(\mathrm{g} 100 \mathrm{~g}_{\text {amostra }}{ }^{-1}\right)$ do óleo bruto extraído de grãos de crambe armazenados em dois tipos de embalagens ao longo do tempo.

\begin{tabular}{cccc}
\hline \multirow{2}{*}{ Embalagem } & \multicolumn{4}{c}{ Tempo } \\
\cline { 2 - 4 } & 0 & 6 & 12 \\
\hline Bolsa & $91,3 \mathrm{Aa}$ & $92,7 \mathrm{Ab}$ & $93,7 \mathrm{Bb}$ \\
Sacaria & $91,3 \mathrm{Ab}$ & $92 \mathrm{Ab}$ & $90,3 \mathrm{Aa}$ \\
\hline
\end{tabular}

Médias seguidas por letras distintas, maiúsculas na coluna e minúsculas nas linhas, diferem pelo "teste t" a $5 \%$ de probabilidade.

O índice de iodo é uma medida do grau de insaturação dos ácidos graxos presentes nos óleos e gorduras. Assim, quanto maior for a insaturação dos ácidos graxos, maior será o índice. O índice de iodo neste estudo apresentou valores na faixa de 91,26 a 94,36 g $100 \mathrm{~g} \mathrm{amostra}^{-1}$. A tendência é que com a perda de insaturações durante o armazenamento, o índice apresente valores menores. Embora os resultados obtidos mostrem poucas mudanças visíveis, pode se notar que o menor valor encontrado foi $(90,19$ g $100 \mathrm{~g} \mathrm{amostra}^{-1}$ ) na (Estufa Agrícola T $25,9^{\circ} \mathrm{C} / \mathrm{UR} 72,8 \%$ ) e o maior valor foi $(94,36 \mathrm{~g}$ $100 \mathrm{~g} \mathrm{amostra}^{-1}$ ) na (Testemunha $\mathrm{T} 25,1^{\circ} \mathrm{C} / \mathrm{UR} 65,4 \%$ ), aos 12 meses de armazenamento. COSTA (2006) encontrou valores de índices de iodo de 92,27 e 93,10 g I/100, corroborando aos obtidos nesse trabalho. Jasper et al. (2010) observaram valor semelhante em óleo bruto de crambe, e o índice de iodo foi de 88 g/100 g. Pohndorf (2012b), ao estudar o índice de iodo em óleo de soja extraído de grãos armazenados em diferentes umidades (12 e $16 \%$ b.u.) e temperaturas $\left(8,13,18,23\right.$ e $\left.28^{\circ} \mathrm{C}\right)$, não encontrou diferença estatística significativa entre os tratamentos empregados. De acordo com Bueno (2007), a composição do biodiesel está diretamente ligada à composição do óleo usado como matéria-prima. A Norma Europeia EN 14214 estabelece que o Índice de Iodo para o biodiesel deve ser menor do que $120 \mathrm{~g} \mathrm{de} \mathrm{I}_{2} / \mathrm{g}$. 


\subsection{3 Índice de Acidez}

Na Tabela 20, são apresentados os valores médios do índice de acidez do óleo bruto de crambe obtidos a partir dos grãos armazenados em duas embalagens diferentes e em três ambientes.

Tabela 20. Valores médios do Índece de Acidez (mg KOH g amostra $^{-1}$ ) do óleo bruto extraído de grãos de crambe armazenados em dois tipos de embalagens e três ambientes.

\begin{tabular}{cccc}
\hline \multirow{2}{*}{ Embalagem } & \multicolumn{3}{c}{ Ambientes } \\
\cline { 2 - 4 } & Testemunha & Estufa & Câmara \\
\hline Bolsa & $1,01 \mathrm{Aa}$ & $0,65 \mathrm{Aa}$ & $0,81 \mathrm{Aa}$ \\
Sacaria & $1,01 \mathrm{Aa}$ & $1,44 \mathrm{Ba}$ & $5,41 \mathrm{Bb}$ \\
\hline
\end{tabular}

Médias seguidas por letras distintas, maiúsculas na coluna e minúsculas nas linhas, diferem pelo "teste t" a $5 \%$ de probabilidade.

Pelos resultados obtidos, o óleo extraído dos grãos armazenados na embalagem sacaria no ambiente (Câmara T $32,5^{\circ} \mathrm{C} / \mathrm{UR} 82$ \%), apresentaram o pior estado de conservação $(5,41 \mathrm{mg} \mathrm{NaOH} / \mathrm{g})$, aos 6 e 12 meses, sendo que as 12 meses foi significativamente maior. Para Tang et al. (2008), entre as consequências negativas da degradação oxidativa do biodiesel, pode ser destacada a elevação da acidez e a formação de gomas e compostos poliméricos indesejáveis. Rodrigues et al. (2013) analisando a qualidade do óleo em sementes de Jatropha curcas L., cultivadas em Moçambique e armazenadas em diferentes condições, observou que o índice de ácidos livres no óleo das sementes armazenadas a $28^{\circ} \mathrm{C}$ a $75 \%$ UR aumentou linearmente ao longo do armazenamento.

$\mathrm{Na}$ Tabela 21, são apresentados os valores médios do índice de acidez do óleo bruto de crambe, acondicionados em diferentes embalagens ao longo de 12 meses de armazenamento.

Tabela 21. Valores médios do Índece de Acidez (mg KOH g $\operatorname{amostra}^{-1}$ ) do óleo bruto extraído de grãos de crambe armazenados em dois tipos de embalagens ao longo do tempo.

\begin{tabular}{cccc}
\hline \multirow{2}{*}{ Embalagem } & \multicolumn{3}{c}{ Tempo } \\
\cline { 2 - 4 } & 0 & 6 & 12 \\
\hline Bolsa & $0,41 \mathrm{Aa}$ & $1,36 \mathrm{Ab}$ & $0,70 \mathrm{Aa}$ \\
Sacaria & $0,41 \mathrm{Aa}$ & $2,41 \mathrm{Bb}$ & $5,04 \mathrm{Bc}$ \\
\hline
\end{tabular}

Médias seguidas por letras distintas, maiúsculas na coluna e minúsculas nas linhas, diferem pelo "teste t" a $5 \%$ de probabilidade. 
$\mathrm{Na}$ Tabela 22, são apresentados os valores médios do índice de acidez do óleo bruto de crambe, acondicionados em diferentes ambientes ao longo de 12 meses de armazenamento.

Tabela 22. Valores médios do Índece de Acidez (mg KOH g amostra $^{-1}$ ) do óleo bruto extraído de grãos de crambe armazenados em três ambientes ao longo do tempo.

\begin{tabular}{cccc}
\hline \multirow{2}{*}{ Ambiente } & \multicolumn{3}{c}{ Tempo } \\
\cline { 2 - 4 } & 0 & 6 & 12 \\
\hline Testemunha & $0,41 \mathrm{Aa}$ & $1,66 \mathrm{Ab}$ & $0,96 \mathrm{Ab}$ \\
Estufa & $0,41 \mathrm{Aa}$ & $1,61 \mathrm{Ab}$ & $1,16 \mathrm{Ab}$ \\
Câmara & $0,41 \mathrm{Aa}$ & $2,39 \mathrm{Ab}$ & $6,54 \mathrm{Bc}$ \\
\hline
\end{tabular}

Médias seguidas por letras distintas, maiúsculas na coluna e minúsculas nas linhas, diferem pelo "teste t" a $5 \%$ de probabilidade.

O óleo de crambe bruto apresenta um elevado índice de acidez, devido à presença de ácidos graxos livres, água, fosfolipídios ou ceras (ONOREVOLI, 2012). O estado de conservação do óleo está intimamente relacionado com a qualidade da matéria prima, principalmente com as condições de conservação durante o armazenamento. O menor valor de índice de acidez $(0,41 \mathrm{mg} \mathrm{NaOH} / \mathrm{g})$ foi encontrado no óleo extraído dos grãos armazenados na embalagem bolsa hermética, no ambiente (Estufa T $25,9^{\circ} \mathrm{C} / \mathrm{UR} 72,8$ $\%$ ), onde também foi encontrado o menor índice de lixiviados pelo teste de condutividade elétrica e o menor teor de água. Isso mostra que a embalagem analisada manteve a qualidade, proporcionando grãos menos deteriorados. $\mathrm{O}$ óleo de crambe possui elevado teor de ácidos graxos de alto peso molecular, e a predominância ocorrente é do ácido erúcico, seguido então do ácido oleico, tornando o óleo impróprio para consumo humano, sendo uma interessante alternativa para a produção de biodiesel (LAGHETTI, 1995; LAZZERI et al., 1997). A oxidação do óleo vegetal pode afetar o índice de acidez e a viscosidade cinemática (DUNN, 2008).

Os valores do índice de acidez obtidos nesse trabalho não estão de acordo com os estabelecidos pela ANP na Resolução $n^{0}$. 7, que estabelece que o limite máximo estipulado para índice de acidez é de $0,5 \mathrm{mg} \mathrm{KOH} \mathrm{g}^{-1}$

\subsubsection{Viscosidade Cinemática à $40{ }^{\circ} \mathrm{C}$}

$\mathrm{Na}$ Tabela 23, são apresentados os valores de viscosidade cinemática a $40^{\circ} \mathrm{C}$ do óleo bruto de crambe, em cada embalagem nos três ambientes. 
Tabela 23 Valores médios de Viscosidade Cinemática $\left(\mathrm{mm}^{2} / \mathrm{s}\right)$ do óleo bruto extraído de grãos de crambe armazenados em dois tipos de embalagens e três ambientes.

\begin{tabular}{cccc}
\hline \multirow{2}{*}{ Embalagem } & \multicolumn{3}{c}{ Ambientes } \\
\cline { 2 - 4 } & Testemunha & Estufa & Câmara \\
\hline Bolsa & $49,7 \mathrm{Aa}$ & $49,5 \mathrm{Ba}$ & $49,6 \mathrm{Aa}$ \\
Sacaria & $49,7 \mathrm{Aa}$ & $49,1 \mathrm{Aa}$ & $49,5 \mathrm{Ab}$ \\
\hline
\end{tabular}

Médias seguidas por letras distintas, maiúsculas na coluna e minúsculas nas linhas, diferem pelo "teste t" a $5 \%$ de probabilidade.

No óleo proveniente dos grãos armazenados no ambiente (Câmara $\left.\mathrm{T} 32,5^{\circ} \mathrm{C} / \mathrm{UR} 82 \%\right)$ foi observado a maior média de viscosidade cinemática à $40^{\circ} \mathrm{C}(49,6$ $\mathrm{mm}^{2} / \mathrm{s}$ ) depois do início do armazenamento. Concordando com os resultados apresentados na Tabela 23, Jasper et al. (2010), obteve valor médio de viscosidade cinemática de $49,02 \mathrm{~mm}^{2} / \mathrm{s}$. De acordo com Wazilewski et al. (2012), o biodiesel produzido a partir do óleo de crambe possui elevada viscosidade cinemática porém, apresenta-se dentro dos limites máximos aceitos pelas normativas.

$\mathrm{Na}$ Tabela 24, são apresentados os valores de viscosidade cinemática a $40^{\circ} \mathrm{C}$ do óleo bruto de crambe, em cada embalagem ao longo de 12 meses de armazenamento.

Tabela 24. Valores médios de Viscosidade Cinemática $\left(\mathrm{mm}^{2} / \mathrm{s}\right)$ do óleo bruto extraído de grãos de crambe armazenados em dois tipos de embalagens ao longo do tempo.

\begin{tabular}{cccc}
\hline \multirow{2}{*}{ Embalagem } & \multicolumn{4}{c}{ Tempo } \\
\cline { 2 - 4 } & 0 & 6 & 12 \\
\hline Bolsa & $49,6 \mathrm{Aa}$ & $49,5 \mathrm{Ba}$ & $49,6 \mathrm{Ba}$ \\
Sacaria & $49,6 \mathrm{Aa}$ & $49,4 \mathrm{Ab}$ & $49,2 \mathrm{Aa}$ \\
\hline
\end{tabular}

Médias seguidas por letras distintas, maiúsculas na coluna e minúsculas nas linhas, diferem pelo "teste t" a $5 \%$ de probabilidade.

Os valores médios de viscosidade cinemática à $40^{\circ} \mathrm{C}\left(49,4 \mathrm{~mm}^{2} / \mathrm{s}\right.$.) mostram um comportamento esperado, em resposta aos métodos de armazenamento ao longo de 12 meses. Até os 6 meses os valores se mantiveram estáveis, depois desse período a viscosidade cinemática á $40^{\circ} \mathrm{C}$ aumentou indicando início de oxidação em função do tempo e do ambiente de armazenamento, sendo que a embalagem bolsa (hermética) se mostrou ineficiente na manutenção da qualidade dos grãos nessa análise avaliativa. 
$\mathrm{Na}$ Tabela 25, são apresentados os valores de viscosidade cinemática a $40^{\circ} \mathrm{C}$ do óleo bruto de crambe, em cada ambiente ao longo de 12 meses de armazenamento.

Tabela 25. Valores médios de Viscosidade Cinemática $\left(\mathrm{mm}^{2} / \mathrm{s}\right)$ do óleo bruto extraído de grãos de crambe armazenados em três ambientes ao longo do tempo.

\begin{tabular}{cccc}
\hline \multirow{2}{*}{ Ambiente } & \multicolumn{3}{c}{ Tempo } \\
\cline { 2 - 4 } & 0 & 6 & 12 \\
\hline Testemunha & $49,6 \mathrm{Aa}$ & $49,6 \mathrm{Ba}$ & $49,6 \mathrm{Ba}$ \\
Estufa & $49,6 \mathrm{Ab}$ & $49,4 \mathrm{Ba}$ & $49,6 \mathrm{Bb}$ \\
Câmara & $49,6 \mathrm{Ac}$ & $49,3 \mathrm{Ab}$ & $49,1 \mathrm{Aa}$ \\
\hline
\end{tabular}

Médias seguidas por letras distintas, maiúsculas na coluna e minúsculas nas linhas, diferem pelo "teste t" a $5 \%$ de probabilidade.

Resultados semelhantes foram obtidos por Wazilewski et al. (2013), que compararam a estabilidade oxidativa do biodiesel, produzido a partir do óleo de crambe e de soja, através da medição da viscosidade cinemática, observaram valores médios de $\left(49,4 \mathrm{~mm}^{2} \mathrm{~s}^{-1}\right)$ superiores ao do óleo de soja (31,5 mm2s-1), que ainda citaram que isto pode ser explicado devido à alta concentração de ácidos graxos com cadeias longas em óleo de crambe, contendo 22 átomos de carbono.

\subsubsection{Massa Específica à $20^{\circ} \mathrm{C}$}

Pelos valores encontrados de massa específica à $20^{\circ} \mathrm{C}$, com média de $0,91 \mathrm{~g} / \mathrm{cm}^{3}$ entre os tratamentos, observa-se que os grãos acondicionados em embalagem hermética e sacaria, apresentaram diferenças significativas no ambiente (Câmara T 32, $5^{\circ} \mathrm{C} / \mathrm{UR} 82 \%$ ), ao final de 12 meses de armazenamento, sendo diferente estatisticamente a partir do sexto mês. Esse mesmo valor foi obtido por Jasper et al. (2010) e Silva (2013), mostrando que não houve efeito do método de armazenagem sobre a massa específica a $20^{\circ} \mathrm{C}$ do óleo bruto de crambe (Tabela 26). 
Tabela 26. Valores médios da Massa Específica $\left(\mathrm{g} / \mathrm{cm}^{3}\right)$ do óleo bruto extraídos de grãos de crambe armazenados em três ambientes ao longo do tempo.

\begin{tabular}{cccc}
\hline \multirow{2}{*}{ Ambiente } & 0 & 6 & 12 \\
\cline { 2 - 4 } & $0,9067 \mathrm{Ab}$ & $0,8060 \mathrm{Aa}$ & $0,9067 \mathrm{Bb}$ \\
Testemunha & $0,9067 \mathrm{Ab}$ & $0,9062 \mathrm{Ba}$ & $0,9064 \mathrm{Aa}$ \\
Estufa & $0,9067 \mathrm{Ab}$ & $0,9063 \mathrm{Ba}$ & $0,9067 \mathrm{Bb}$ \\
Câmara &,
\end{tabular}

Médias seguidas por letras distintas, maiúsculas na coluna e minúsculas nas linhas, diferem pelo "teste t" a $5 \%$ de probabilidade. 


\section{CONSIDERAÇÕES FINAIS}

A embalagem bolsa (hermética) foi capaz de resistir às influências das condições ambientes nos aspectos avaliativos teor de água e condutividade elétrica nos grãos. A sacaria (convencional) ficou mais suscetível às variações das condições ambientes durante o armazenamento, proporcionando maior exposição dos grãos, por meio dos resultados das análises de qualidade do grão e do óleo.

Os grãos quando submetidos ao armazenamento na câmara climatizada, apresentaram evidencias de deterioração em todos os quesitos avaliativos, nas embalagens e bolsa (hermética) e sacaria (convencional).

O tempo de armazenamento foi um fator que apresentou médias estatisticamente maiores para todas as análises avaliativas, a partir do sexto mês de armazenamento, se intensificando ao final dos 12 meses, independente do tipo de embalagem, indicando insegurança nos aspectos qualitativos.

O aspecto avaliativo teor de óleo nos grãos aumentou significativamente nas duas embalagens no fim do armazenamento, por isso, recomenda-se que sejam realizados mais estudos para verificar a ação de enzimas na transformação de açúcar em lipídeos ao longo do armazenamento. Além disso, recomenda-se a realização de análises de monitoramento da quantidade de oxigênio existente no interior das embalagens para justificar a qualidade proporcionada pelo tratamento hermético.

Devido à influência negativa da ação de fungos nos tratamentos aplicados, recomenda-se a realização de análises quantitativa do desenvolvimento de fungos durante o armazenamento. 
As análises de qualidade realizadas no óleo bruto do crambe apontam que o índice de iodo e o índice de acidez apresentaram valores médios significativamente melhores na embalagem bolsa hermética, demonstrando melhor eficiência na manutenção da matéria prima para a produção do biodiesel. 


\section{CONCLUSÕES}

Pelos resultados obtidos nesse trabalho pode-se afirmar que:

Houve efeito da embalagem hermética na qualidade dos grãos armazenados, para os aspectos avaliativos teor de água e condutividade elétrica.

O tempo de 12 meses de armazenamentos apresentou níveis inseguros de qualidade para os grãos de crambe, independente da embalagem e do ambiente.

Os grãos quando submetidos ao armazenamento no ambiente câmara climatizada, apresentaram evidencias de deterioração em todos os quesitos avaliativos, nas embalagens bolsa (hermética) e sacaria (convencional).

As análises de qualidade realizadas no óleo bruto do crambe apontam que o índice de iodo e o índice de acidez apresentaram valores médios significativamente melhores na embalagem bolsa hermética, demonstrando melhor eficiência na manutenção da matéria prima para a produção do biodiesel. 


\section{REFERÊNCIAS BIBLIOGRÁFICAS}

ALENCAR, E. R. Efeitos das condições de armazenagem sobre a qualidade da soja (Glycine max (L.) Merril) e do óleo bruto. 2006. 117 f. Dissertação (Mestrado em Engenharia Agrícola) Universidade Federal de Viçosa. Viçosa - MG, 2006.

ALENCAR, E. R. de et al. Qualidade dos Grãos de Soja em Função das Condições de Armazenamento. Engenharia na Agricultura, Viçosa - MG, v. 16, n. 2, p.155-166, jun. 2008 .

ALENCAR, E. R. de et al. Qualidade dos grãos de soja armazenados em diferentes condições. Revista Brasileira de Engenharia Agrícola e Ambiental, v.13, n.5, p.606-613, 2009.

ALENCAR, E. R. de et al. Qualidade dos grãos de soja armazenados em diferentes condições. Revista Brasileira de Engenharia Agrícola e Ambiental, v.13, n.5, p.606-613, $2009 b$.

ALENCAR, Ernandes R. de et al. Influence of soybean storage conditions on crude oil quality. Rev. bras. eng. agríc. ambient. [online]. 2010, v.14, n.3, p. 303-308. ISSN $1807-$ 1929.

AMARAL, F. P. Estudo das características físico-químicas dos óleos da amêndoa e da polpa da macaúba [Acrocomiaaculeata (Jacq.) Lodd. ex Mart]. 66f. 2007 Dissertação. Mestrado em Agronomia (Energia na Agricultura). Faculdade de Ciências Agronômicas. Universidade Estadual Paulista "Júlio de Mesquita Filho". Botucatu-SP. 2007.

AMERICAN ASSOCIATION OF CEREAL CHEMISTS. Approved methods of the AACC.8.ed. Saint Paul : AACC, 1995. Paginação irregular. 
ANVISA. Agência Nacional de Vigilância Sanitária. Resolução no 482 de 23 de setembro de 1999. Disponível em: <http://www.anvisa.gov.br/legis/resol/482_99.htm>. Acesso em: out. 2012.

AZEVEDO, M. R. Q. A.; GOUVEIA, J. P. G.; TROVÃO, D. M. M.; QUEIROGA, V. P. Influência das embalagens e condições de armazenamento no vigor de sementes de gergelim. Revista Brasileira de Engenharia Agrícola e Ambiental, Campina Grande, v.7, n.3, p. 519-524, 2003.

BAUDET, L. Armazenamento de Sementes. In: PESKE, S. T.; ROSENTHAL, M. D.; ROTA, G. M. (Ed.) Sementes: fundamentos científicos e tecnológicos. Pelotas: Gráfica Universitária - UFPEL, 2003, p. 369-418.

BAUDET, L. (2003) Armazenamento de sementes. In: Peske ST, Rosental MD \& Rota GR (Eds.) Sementes: fundamentos científicos e tecnológicos. Pelotas, UFPel. p.369-418

BERALDO, J. M. G. Determinação da época de semeadura do Crambe (Crambe abyssinica Hochst) na região nordeste do Estado de São Paulo-SP. $4^{\circ}$ Congresso da Rede Brasileira de Biodiesel, $7^{\circ}$ Congresso Brasileiro de plantas Oleaginosas, Óleos, Gorduras e Biodiesel. In: (Anais...) Belo Horizonte-MG. 2010.

BERTINETTI, I. A.; OLIVEIRA, M.; OLIVEIRA, L. C. de; VANIER, N. L.; ELIAS, M. C. XX CONGRESSO DE INICIAÇÃO CIENTÍFICA. Efeitos da Hermeticidade no Armazenamento de Soja sobre Rendimento e Qualidade de Grãos e do Óleo para Biodiesel. (Anais ...) Mostra Científica UFPEL, Pelotas - RS. 2011. 5 p.

BIAGGIONI, M. A. M.; BARROS, R. E. Teste de acidez graxa como índice de qualidade em arroz. Ciênc. Agrotec, Lavras - MG, v. 30, n. 4, p.680 - 684, fev. 2006.

BISPO, A. S. et al. Caracterização de óleos vegetais extraídos mecanicamente sob condições variadas, visando a produção de biodiesel. In: $4^{\circ}$ Congresso da Rede Brasileira de Tecnologia de Biodiesel; $7^{\circ}$ Congresso Brasileiro de Plantas Oleaginosas, Óleos, Gorduras e Biodiesel, (Anais... ) TECPAR, Belo Horizonte, MG: 2010.

BORDIGNON, B. C. S. Relação das condições de armazenamento com a qualidade fisiológica de sementes e composição do óleo extraído de cultivares de soja. $2009.90 \mathrm{f}$. Dissertação (Mestrado) - Curso de Curso de Mestrado do Programa de Pós-graduação em Agronomia, Área de Concentração em Produção Vegetal, Universidade Federal de Santa Maria, Santa Maria - RS, 2009. 
BRANGANTINI, C. Alguns Aspectos do Armazenamento de Sementes e Grãos de Feijão. Documento Técnico. Santo Antônio de Goiás: Embrapa Arroz e Feijão. 2005.

BRASIL. Lei no . 11.097, de 13 de Janeiro de 2009. Dispõe sobre a criação do Programa Nacional de Produção e Uso do Biodiesel e sobre a adição de biodiesel ao óleo diesel. Disponível em: www.anp.gov.br.Acesso em 02/09/11.

BUENO, Luciano de Souza Ribeiro. Estudo da Influencia da composição do óleo vegetal sobre algumas propriedades do biodiesel. 2007. Dissertação de Mestrado em Engenharia Mecânica - Centro de Ciências Exatas e Tecnologicas, Pontificia Universidade Católica do Parana, Curitiba - PR, 2007

BARTOSIK, R.; RODRÍGUEZ, J.; CARDOSO, L. (2008). Storage Of corn, wheat, soybean and sunflower in hermetic plastic bags. In: International Grain Quality \& Technology Congress Proceedings, Chicago, Illinois, USA. 2008.

CARDOSO M. L.; BARTOSIK R. E.; RODRÍGUEZ J. C.; OCHANDIO D. (2008). Factors affecting carbon dioxide concentration in interstitial air of soybean stored in hermetic plastic bags (silo-bag). In: The Proceedings of the 8th International Conference on Controlled Atmosphere and Fumigation in Stored Products, Chengdu, China. (2008).

CASTRO, R. S. D. Avaliação das características organolépticas de grãos e qualidade fisiológica de sementes em função do tempo de armazenamento em amendoim. 2010. 49 f. Dissertação. (Mestrado em Agronomia / Sistemas de Produção). Ilha solteira - SP. 2010 .

CARNEIRO, S. M. et al. Ocorrência de Alternaria brassicicolaem crambe (Crambe abyssinica) no estado do Paraná. Comunicações. Summa Phytopathol. Botucatu, v. 35, n. 2, p. 154. 2008.

CONAB Companhia Nacional de Abastecimento. Capacidade estática de armazenagem cadastrada. Resumo Total Brasil. Disponível em: http:/www.conab.gov.br/ projinfogerenciais/resumo-capac-popup.asp> Acesso em: 30 abr. 2012.

COSTA, T. L. Características físicas e físico-químicas do óleo de duas cultivares de mamona. 2006. 113f. Dissertação. Mestrado em Engenharia Agrícola (Armazenamento e Processamento de Produtos Agrícolas). Universidade Federal de Campina Grande.

Campina Grande, 2006. 
COSTA, A. R. et al. Qualidade de grãos de milho armazenados em silos bolsa. Revista

Ciência Agronômica, v. 41, n. 02, p. 200-207, 2010.

COSTA, L. M. et al. Qualidade dos frutos de crambe durante o armazenamento. Revista Brasileira de Sementes, vol. 34, nº 2 p. 239 - 301, 2012.

COSTA, Lílian Moreira et al. Crambe seeds quality during storage in several conditions. African Journal Of Agricultural Research, Parakou, v. 8, n. 14, p.12581264, 18 abr. 2013.

CHRISTENSEN, C. M.; KAUFMANN, H. H. Grain storage: the role of fungi in quality loss. Minneapolis: University of Minnesota Press. 154 p. 1969.

DARBY J.A.; CADDICK L. P. Review of grain harvest bag technology under Australian conditions. Canberra: CSIRO Entomology, 112 p. 2007.

DAVIDE, A. C.; CARVALHO, L. R.; CARVALHO, M. L. M.; GUIMARÃES, R. M. Classificação físiológica de sementes de espécies florestais pertencentes à família Lauraceae quanto à capacidade de armazenamento. Revista Cerne, Lavras, v.9, n.1, p. 29 $35,2003$.

DELIBERALI, J. et al. Efeitos de processo de secagem e tempo de armazenamento na qualidade tecnológica de trigo. Ciênc. Agrotec, Lavras - MG, v. 24, n. 5, p.185-1292, set. 2010 .

DEMITO, A. Qualidade de sementes de soja resfriadas artificialmente. 2006. 65f. Dissertação (Mestrado em Engenharia Agrícola). Centro de Ciências Exatas e Tecnológicas, Universidade Estadual do Oeste do Paraná, Cascavel. 2006.

DHINGRA, O.D.; JHAM, G.; NAPOLEÃO, I.T. Ergosterol accumulation and oil quality changes in stored soybean invaded by Aspergillus ruber (A. glaucus group).

Mycopathologia, Springer, v.143, p.85-91, ago. 1998.

DUNN, R.O., 2008. Antioxidants for improving storage stability of biodiesel. Biofuel Bioprod. Bior. 2, 304-318.

ELI AS, M. C. Manejo tecnológico da secagem e do armazenamento de grãos. Pelotas. Ed. Santa Cruz. 362 p. 2008. 
ELIAS, M.C.; ROMBALDI, C.V.; SILVA, J.A.; NORA, L.; DIAS, A.R.G. Secagem e armazenamento de grãos: sistemas, processos e métodos. Pólo de Modernização Tecnológica em Alimentos da Região Sul do Rio Grande do Sul. UFPEL-FAEMDCTA. Pelotas, 52p. 1997.

ELIAS, M.C.; SILVA, L.H.; CALDASSO, L.H.S.; GHESTI, C.J. Armazenamento hermético de milho em pequena escala. In: Reunião Anual de Pesquisa da Cultura do Milho, 45, Porto Alegre, 2002. (Anais ...) FEPAGRO-EMBRAPA-EMATER, Porto Alegre, 6 p. 2002.

FARIA, R. Q. Cinética de secagem e qualidade fisiológica das sementes de crambe. Dissertação. (Mestrado em Engenharia Agrícola). Universidade Estadual de Goiás. 2010.

FARONI, L. R. D. et al. Avaliação qualitativa e quantitativa do milho em diferentes condições de armazenamento. Engenharia na Agricultura, Viçosa - MG, v. 3, n. 13, p.193-201, set. 2005.

FARONI, L. R. A. et al. Armazenamento de soja em silos tipo bolsa. Engenharia Agrícola, v. 29, n. 01, p. 91-100, 2009.

FARONI, L. R.A. et. al. Armazenamento de soja in silos Tipo bolsa. Eng. Agríc. [online]. vol.29, n.1, pp 91-100. ISSN 0100-6916. 2009.

FERNANDES et al. Análise de teor de água e sedimento do óleo da Samaúma (ceibapentandra). $2^{\circ}$ Simpósio Nacional de Biocombustíveis. Recife-PE. (Anais...) 2009.

FERREIRA, F. M.; BERCHOL SILVA, A. R. Produtividade de grãos e teor de óleo da cultura do Crambe sob diferentes sistemas de manejo de solo em Rondonópolis - MT. Enciclopédia Biosfera, Centro Científico Conhecer-Goiânia, vol. 7, n. 12. 2011.

FLEURAT-LESSARD, F. Qualitative reasoning and integrated management of the quality of stored grain: a promising new approach. Journal of Stored Products Research, v.38, p.191-218, 2002.

FUNDAÇÃO MATO GROSSO DO SUL. Crambe FMS Brilhante. Maracajú, 2007. Disponível em: <http://www.fundacaoms.org.br/page.php?34>. Acesso em: 11 de outubro de 2011. 
FUNDAÇÃO MATO GROSSO DO SUL. Crambe FMS Brilhante. Maracajú, 2009. Disponível em: <http://www.fundacaoms.org.br/page.php?34>. Acesso em: $11 \mathrm{de}$ outubro de 2011.

GOLDEMBERG, J. Biomassa e Energia; Química Nova, 2009, 32, 3, p 582-587.

GOMES, JR. S. B. Avaliação Técnica e econômica da aplicação do óleo vegetal de crambe como isolante elétrico com comparação com o óleo de soja (Trabalho de conclusão de mestrado profissional). Instituto de Tecnologia para o Desenvolvimento LACTEC e Instituto de Engenharia do Paraná - IEP. Curitiba, PR. 2010.

GONZÁLEZ-TORRALBA, Jon et al. Influence of temperature and r.h. during storage on wheat bread making quality. Journal Of Stored Products Research, Pamplona, Navarra, Spain, v. 55, n. 8, p.134-144, out. 2013.

HOU, H. J.; CHANG, K.C. Storage conditions affect color, chemical composition and tofu qualities. J Food Proc Pres 28:473-488, 2004.

JASPER, S. P. Cultura do crambe (Crambe abyssinica Hochst): Avaliação energética, de custo de produção e produtividade em sistema de plantio direto. $103 \mathrm{f}$. Tese (Doutorado em Agronomia/Energia na Agricultura) - Faculdade de Ciências Agronômicas, Universidade Estadual Paulista, Botucatu, 2009.

JIAN, F.; JAYAS, D. S.; WHITE, N. D. G. Temperature fluctuations and moisture migration in wheat stored for 15 months in a metal silo in Canada. Journal of Stored Products Research 45.82 - 90 p. 2009.

JUNK-KNIEVEL, D. C.; VANDERBERG, A.; BETT, K. E. Slow darkening in pinto bean (Phaseolus vulgarisL.) seed coats is controlled by a single major gene. Crop Science 49, p. 189 - 193. 2008.

$\mathrm{KOCH}, \mathrm{H}-\mathrm{J}$. et al. Evaluation of environmental and management effects on Fusarium head blight infection and deoxynivalenol concentration in the grain of winter wheat. European Journal of Agronomy, v.24, n.2, p. 357-366, 2006.

LEE, J.H.; CHO, K.M. Changes occurring in compositional components of black soybeans maintained at room temperature for different storage periods. Food Chemistry. v. 131, p. 161-169, 2012. 
LAGHETTI, G.; et al. Yield and oil quality in selected lines of Crambe abyssinica grow in Italy. Industrial crops and products, Itália. 1995.

LAZZERI, L.; DE MATTEI, F.; et al. Crambe oil - a potencial new hidraulic oil and quenchant. Industrial Lubrication and Tribology. Vol.49, n.2, pag. 71-77. 1997.

LAZZARI, F. A. Umidade, fungos e micotoxinas na qualidade de sementes, grãos e rações. 2. ed. Curitiba: [s.n.]. 148 p. 1997.

LAZZAROTTO, J. J.; HIRAKURI, M. H. Avaliação econômica da produção de soja no Estado do Paraná, para a safra 2009/10. Londrina: Embrapa Soja, (Embrapa Soja. Circular Técnica, 72). 22 p. 2009.

LÊDA R. A. et al. Armazenamento de soja em silos tipo bolsa. Eng. Agríc., Jaboticabal, v. 29, n. 1, p. 91-100, maio 2009.

LIMA, L. B.; Avaliação do potencial fisiológico e métodos de condicionamento, secagem e armazenamento de sementes de pepino. 2008. $93 \mathrm{f}$. Tese (Doutorado em Fitotecnia) - Escola Superior de Agronomia Luiz de Queiroz, Universidade de São Paulo, Piracicaba, 2008.

Liu, Z.-H., Qin, L., Jin, M.-J., Pang, F., Li, B.-Z., Kang, Y., Dale, B.E., Yuan, Y.-J., 2013. Evaluation of storage methods for the conversion of corn stover biomass to sugars based on steam explosion pretreatment. Bioresource Technol. 132, 5-15.

V MARINI, L.J. et al. Efeito da secagem intermitente na estabilidade de grãos de aveia. Brazilian Journal of Food Technology, v.8, n.3, p.260-267, 2005.

MARINI, L.J. et al. Efeito da secagem intermitente na estabilidade de grãos de aveia. Brazilian Journal of Food Technology, v.8, n.3, p.260-267, 2005 b.

MASETTO, T Athiana Elisa et al. Armazenamento de sementes de Crambe abyssinicaHochst. ex R.E.Fr . em diferentes embalagens e ambientes. Rev. Ceres, Viçosa,Dourados/ms, v. 60, n. 5, p.646-652, out. 2013

MATOS, V. P. et al. Efeito do tipo de embalagem e do ambiente de armazenamento sobre a germinação e o vigor das sementes de apeiba tibourbouaubl. R. Árvore, Carpina - Pe, v. 32, n. 4, p.617-625, 2008. 
MUIR, W. E. Stored grain losses. In: MUIR, W. E. (Ed.). Grain preservation biosystems. Winnipeg: Department of Biosystems Engineering, University of Manitoba. 2000. p. 12-16 (paginação irregular). Disponível em: <jajo66.files.wordpress.com/2008/10/grainpreservation-biosystem.pdf $>$. Acesso em: out. 2012.

MUNSELL, A. H. Munsell book of color. Baltimore: Macbeth Division of Kollmorgen, 1976.(Mathefinish collection).

NASAR-ABBAS, S.M., SIDDIQUE, K.H.M., PLUMMER, J.A., WHITE, P.F., HARRIS, D., DODS, K.,ANTUONO, M.D., 2009. Faba bean (Vicia fabaL.) seeds darken rapidly and phenolic content falls when stored at higher temperature, moisture and light intensity. Food Science and Technology 42, 1703e1711. 2009.

NITHYA, U.; CHELLADURAI, V.; JAYAS, D. S.; WHITE, N. D. G. Safe storage guidelines for durum wheat. Journal of Stored Products Research, v.47, n.4,p.328 - 333, 2011 .

O'BRIEN, R.D. Fat an oils. In: O'BRIEN, R.D. (Ed.). Fats and oils formulating and processing for applications. Boca Raton: CRC Press, 2004. p.175-232.

OLIVA, A. C. E. Qualidade de sementes de crambe submetidas a métodos de secagem e períodos de armazenamento. 2010. 87 f. Dissertação. (Mestrado em Agronomia / Energia na Agricultura). Faculdade de Ciências Agronômicas. Universidade Estadual Paulista "Júlio de Mesquita Filho". Botucatu-SP. 2010.

OLIVA, Ana Cristina Ensinas de. Qualidade de sementes de crambe submetidas a métodos de secagem e períodos de armazenamento. 2010. $87 \mathrm{f}$. Dissertação (Mestrado Curso de Pós-graduação em Agronomia, Departamento de Engenharia Rura). Universidade Estadual Júlio de Mesquita Filho, Botucatu - SP, 2010.

OLIVEIRA, M. et. al. Efeitos das condições ambientais e do tempo de armazenamento de soja sobre a qualidade do óleo para produção de biodiesel. Simpósio Estadual de Agroenergia - RS. (Anais...) 2007.

OLIVEIRA, F.A.; KHATCHATOURIAN, O.A.; BIHAIN, A. Estado térmico de produtos armazenados em silos com sistema de aeração: estudo teórico e experimental. Engenharia Agrícola, Jaboticabal, v.27, n.1, p.247-258, 2007. 
OLIVEIRA, M.et al. Efeitos do tempo e do armazenamento refrigerado de grãos de soja sobre a qualidade do óleo. $5^{\text {a }}$ Conferência Brasileira de Pós Colheita. (Anais...). Foz do Iguaçú - PR. 2010.

OLIVEIRA, M.et al. Efeitos do tempo e do armazenamento refrigerado de grãos de soja sobre a qualidade do óleo. $5^{\text {a }}$ Conferência Brasileira de Pós Colheita. (Anais...). Foz do Iguaçú - PR. 2010.

OLIVEIRA, M. de. Efeitos da umidade, do tempo e de sistemas de armazenamento sobre parâmetros de qualidade e propriedades tecnológicas dos grãos e do óleo de soja. Tese (Doutorado em Ciência e Tecnologia Agroindustrial) - Faculdade de Agronomia Eliseu Maciel, Universidade Federal de Pelotas, Pelotas, Abril de 2011.

/ONOREVOLI, B. Estudo do Crambe abyssinica como Fonte de Matérias Primas oleaginosas: óleo vegetal, ésteres metílicos e bio-óleo. Dissertação (Mestrado), Universidade Federal do Rio Grande do Sul. Porto Alegre-RS. 2012.

OPLINGER, E.S. et al., Crambe, alternative field crops manual. University of Wisconsin and University of Minnesota. St. Paul, MN 55108. July, 1991.

ORTOLAN, F. Genótipos de trigo do Paraná - safra 2004: Caracterização e fatores relacionados à alteração da cor de farinha de trigo. 2006. 128f. Dissertação (Mestrado em Ciência e Tecnologia dos Alimentos) - Centro de Ciências Rurais, Universidade Federal de Santa Maria, Santa Maria. 2006.

ORTOLAN, F. et al., Efeito do armazenamento à baixa temperatura $\left(-4^{\circ} \mathrm{C}\right)$ na cor e no teor de acidez da farinha de trigo. Ciênc. Tecnol. Aliment., 30, 55-59. 2010.

PARAGINSKI, R. T. et al., Characteristics of starch isolated from maize as a function of grain storage temperature, Carbohydrate Polymers (2013), http://dx.doi.org/10.1016/j.carbpol.2013.11.019

PARK, C. et al. Changes in physicochemical characteristics of rice during storage at different temperatures. Journal of Stored Products Research, Republic Of Korea, v. 48, n. 8, p.25-29, 2012.

PITOL, C.; BROCH, D. L.; ROSCOE, R. Tecnologia e Produção: Crambe 2010. Maracaju: Fundação MS. 60p. 2010. 
PLEIN, G.S. et al., Caracterização de Fração Lipídica de Sementes de Crambe Armazenadas com e sem Casca. IV Comgresso Brasileiro de Mamona e I Simpósio Internacional de Oleaginosas Energéticas, João Pessoa, PB. 2010. Disponível em: http://www.cbmamona.com.br/pdfs/OLE-17.pdf. Acessado em outubro de 2012.

PEREZ, S. C. J. G. A. Limites de temperatura e estresse térmico na germinação de sementes de Peltophorium dubium. Revista Brasileira de Sementes, Londrina, v. 20, n.1, p. 134-142, 1998.

POHNDORF, R. S. Efeitos da umidade e do resfriamento no armazenamento sobre a qualidade de grãos e do óleo de soja para fins comestíveis e de produção de biodiesel. 2012. 68 f. Dissertação (Mestrado) - Curso de Programa de Pós-graduação em Ciência e Tecnologia Agroindustrial, Universidade Federal de Pelotas, Pelotas - Rs, 2012.

PUZZI, D. Armazenamento e Abastecimento de Grãos. Campinas, Instituto Campineiro de Ensino Agrícola, 603p. 1986.

QUEIROGA, V.P. et al. Qualidade de sementes de algodão armazenadas em função de diferentes cultivares e teores de água. Revista Caatinga, 22:136-144. 2009.

QIANG, L.; WEN-ZHI, L.; XI-FENG, Z. Overview of fuel properties of biomass fast pyrolysis oils. Energy Conversion and Management, 50, p 1376-1383. 2009.

REED, C. et al. Response of storage molds to different initial moisture contents of maize (corn) stored at $25^{\circ} \mathrm{C}$, and effect on respiration rate and nutrient composition. Journal of Stored Products Research. v. 43, n. 04, p. 443-458, 2007.

RESENDE, O. et al. Avaliação qualidade tecnológica do feijão: Qualidade tecnológica do feijão 517 durante o armazenamento. Ciênc. Agrotec, Lavras - Mg, v. 32, n. 2, p.517-524, abr. 2008 .

RIOS, A. O.; ABREU, C. M. P.; CORRÊA, A. D. Efeito da estocagem e das condições de colheita sobre algumas propriedades físicas, químicas e nutricionais de três cultivares de feijão (Phaseolus vulgaris L.). Ciência e Tecnologia de Alimentos, Campinas, v. 23, p. 39-45, 2003.

RODRIGUES, Joana et al. Variability in oil content and composition and storage stability of seeds from Jatropha curcas L. grown in Mozambique. Industrial Crops And Products, Lisbon - Portugal, v. 50, n. 3, p.828-837, 16 ago. 2013. 
RUPOLLO, G. et al. Efeito da umidade e do período de armazenamento hermético na contaminação natural por fungos e a produção de microtoxinas em grãos de aveia. Ciência e Agrotecnologia, v. 30, n. 01, p. 118-125, 2006.

RUTZ, Daniel. Efeitos da temperatura e do tempo de armazenamento do trigo sobre parâmetros de avaliação da qualidade dos grãos e das farinhas. 2012.85 f. Dissertação (Mestrado) - Curso de Programa de Pós-graduação em Ciência e Tecnologia de Alimentos, Universidade Federal de Pelotas, Pelotas - RS, 2012.

SANTOS, Silmara Bispo dos. Determinação da perca de matéria seca e avaliação qualitativa de grãos de milho armazenados em bolsas herméticas. $2008.7 \mathrm{f}$.

Dissertação (Mestrado) - Curso de Pós-graduação em Engenharia Agrícola, Universidade Federal de Viçosa, Viçosa, 2008.

SANTOS, J. I.; ROGÉRIO, F.; MIGLIAVACCA, R. A.; et al. Efeito da Adubação Potássica na Cultura do Crambe. Biosci. J., Uberlândia, v. 28, n. 3, p. 346-350. 2012. 31.

SATHYA, G.; JAYAS, D.S.; WHITE, N.D.G. Safe storage guidelines for canola as the seeds slowly dry. Canadian Biosystems Engineering 51, p. 329 - 338. 2009.

SILVA, J. S. Secagem e armazenagem de produtos agrícolas. Viçosa: Aprenda Fácil, 502p. 2000.

SILVA, T. A. et al. Qualidade do óleo bruto extraído da soja armazenada em silos bolsa. $5^{\text {a }}$ Conferência Brasileira de Pós Colheita. (Anais...). Foz do Iguaçú - PR. 2010.

SILVA. M. P. A. et al. Qualidade do óleo bruto de grãos de crambe (crambe Abyssinica hochst) sob diferentes métodos de secagem). Energia na Agricultura, Botucatu, v. 28, n. 3, p. 193-199, 2013.

SOARES, T. A.; BIAGGIONI, M. A. M.; FRANÇA NETO, J. B. Análise da acidez graxa como índice de qualidade em grãos de soja. Energia na Agricultura, Botucatu, v. 20, n. 1, p. $91-102,2005$.

SRAVANTHI, B. et al. Effect of storage conditions on red lentils. Journal Of Stored Products Research, Canada, v. 53, n. 8, p.48-53, 2013. 
TOEBE, M.; BRUM, B.; LOPES, S. J.; et al. Estimativa da área foliar de Crambe abyssinica por discos foliares e por fotos digitais. Ciência Rural, Santa Maria, v.40, n.2, p.475-478. 2010.

TONIN, G. A.; PEREZ, S. C. J. G. A. Qualidade fisiológica de sementes de Ocotea porosa (Nees et Martius ex. Nees) após diferentes condições de armazenamento e semeadura.

Revista Brasileira de Sementes, Pelotas, v. 28, n. 2, p. 26-33, 2006.

VANIER, N. L. et al. Efeito da hermeticidade e do tempo de armazenamento sobre o comportamento na cocção do feijão carioca. In: conferência brasileira de pós-colheita, 5 . Foz do Iguaçu - Pr. Londrina - PR: ABRAPOS. 2010. v. 1. p. 711 - 715.

VILLERS, P.; BRUIN, T.; NAVARRO, S. Safe storage of grain in the tropics: A comparison of hermetic storage in flexible silos versus rigid metal or concrete silos. Feed Technology Update. Honolulu: Linx Publishing. p. 17-22. 2006.

Villers, P. Safe Storage of Grain in the Tropics. Feed Technology Update v.1 n. 3. 2006.

VILLERS, P. et al. New applications of hermetic storage for grain storage and transport. Julius-kühn-archiv, Israel, v. 425, n. 8, p.446-451, ago. 2010.

WAGNER, M. H.; DUCOURNAU, S. Conductivity testing for oilseed rape seeds. ISTA News Bulletin, n. 133, Apr., 2007. Disponível em:

$<$ http://www.seedtest.org/upload/cms/user/STI133April2007.pdf $>$. Acesso em: 13 nov. 2011.

WAZILEWSKI, W.T.; ROSA, H.A.; et al. Avaliação de Propriedades Físico-químicas do Biodiesel Metílico de Óleo de Crambe abyssinica hochst. Jornal of Agronomic Science, v.1, n.1, pag. 187-195. 2012

WAZILEWSKI, W. T.et al. Study of the methyl crambe (Crambe abyssinica Hochst) and soybean biodiesel oxidative stability. Industrial Crops And Products,Cascavel - Pr, v. 43, n. 8, p.207-212, 2013.

WEINBERG, Z. G. et al. The effect of moisture level on high-moisture maize (Zea maysL.) under hermetic storage conditions - in vitro studies. Journal of Stored Products Research, Israel, v. 44. p. 136-144. 2008. 
WEINBERG, Z. G. et al. The effect of moisture level on high-moisture maize (Zea maysL.) under hermetic storage conditions - in vitro studies. Journal of Stored Products Research, Israel, v. 44, p.136-144, 2008 b.

ZENI, D. B. et al. Anais Conferência Brasileira de Pós-Colheita. In: Conferência Brasileira de Pós-colheita, 5. 2010, Foz do Iguaçu - PR. Efeito do tempo e da umidade relativa do ar na armazenagem sobre parâmetros tecnológicos no óleo para biodiesel. Londrina - PR: ABRAPOS, p. 722 - 727. 2010.

Zhou, Z.; Robards, K.; Helliwell, S.; Blanchard, C. Ageing of stored rice: changes in chemical and physical attributes. Journal of Cereal Science, v.35, p.65-78, 2002 